UC-70

Issued: August 1985

LA- - $10479-M S$

DE86 003281

\title{
TRU Waste-Sampling Program
}

\author{
John L. Warren \\ Al Zerwekh*
}

\section{DISCLAIMER}

This report was prepared as an account of work sponsored by an agency of the United States Government. Neither the United States Government nor any agency ttereof, nor any of their employees, makes any warranty, express or implied, or assumes any legal liability or responsibility for the accuracy, completeness, or usefulness of any information, apparatus, product, or process disclosed, or represents that its use would not infringe privately owned rights. Reference herein to any specific commercial product, process, or service by trade name, trademark, manufacturer, or otherwise does not necessarily constitute or imply its endorsement, recommendation, or favoring by the United States Government or any agency thereof. The views and opinions of authors expressed herein do not necessarily state or reflect those of the United States Government or any agency thereof. 
Abstract 1

Introduction 2

Retrieving the Waste 2

The 30-ga11on Drums -- 238 $\mathrm{Pu-contaminated} \mathrm{Waste} 2$

The 55-gallon Drums - $239 \mathrm{Pu}$-contaminatad Waste 7

Gas Sampling and Analysis 12

Vold Volumes and G Values 21

Rea1-Time Rad1ography 22

Wa11 Th1ckness of Drums 24

$\begin{array}{ll}\text { Assay of TRU Content } & 27\end{array}$

Drum Opening, Waste Inspection, and Sampling 27

Sludge Core Aralyses 29

Discussion of Studies 34

$\begin{array}{ll}\text { Sumary } & 38\end{array}$

$\begin{array}{ll}\text { Acknowledgments } & 39\end{array}$

References

Append1x 1: Los Alamos Waste Form Codes 40

Append1x 2: Waste Drum Sumar\% Sheets 42

Appendix 3: Wasto Contalner Component Weights 87

Append1x 4: Waste Form Compliance with the WIPP-WAC 91 
John L. Warren and Al Zerwekh

\section{ABSTRACT}

As part of a TRU waste-sampling program, Los Alamos National Laboratory retrieved and examined 44 drums of $238 \mathrm{pu}-$ and $239 \mathrm{Pu}-\mathrm{contaminated}$ waste. The drums ranged in age from 8 months to 9 years.

The majority of drums were tested for pressure, and gas samples withdrawn from the drums were analyzed by a mass spectrometer. Real-t1me radiography and visual examination were used to determine both vold volumes and waste content. Drum walls were measured for deterioration, and selected drum contents were reassayed for comparison with original assays and WTPP criteria.

Each drum tested at atmosphertc pressure. Mass spectrometry revealed no problem with 239 pucontaminated waste, but three 3-month-old drums of 238 Eu-contaminated waste contained a potentially hazardous gas mixture. Vold volumes fell within the $81-97 \%$ range. Measurements of drum walls showed no significant corrosion or deterioration. All reassayed contents were within WIP $\bar{P}$ waste acceptance crlterla.

Five of the drums opened and examined ( $15 \%)$ could not be certified as packaged. Three contained free liquids, one had corrostve materlals, and one had too much unstablified particulate. Eleven drums had the wrong (or not the most appropriate) waste cote. In many cases, disposal voiumes had been inefficiently used. 
Early In 1983 the Transuranic Waste Systems Offlce 1dentified a TRU waste-sampling program for EG $\&$ G Idaho, Rocky Flats Plant, and Los Alamos National Laboratory, which would contribute to an overall national plan to certify radioactive waste for the Waste Isolation P1lot Plant.

As 1 ts share of the work, Los Alamos was asked to retrieve and examine a minimum of 32 drums of $238 \mathrm{pu}$ - and $239 \mathrm{Pu}$-contaminated waste, perform nondastructive examinations of the drums contalning the waste, measure gas pressure in the drums and analyze the gaseous contents of each drum, determine the drum vold volumes, and examine and characterize the drums' contents for compliance with the WIP? waste acceptance criteria (WAC). The last objective requlred opening many of the drums in the Los Alamos Size Reduction Facility (SRF).

\section{RETRIEVING THE WASTE}

The 30-ga11on Drums - $238 \mathrm{pu}-$ contaminated Waste

The first step was the retrieval of eighteen 30-gallon drums containing $238 \mathrm{pu}$-contaminated waste. Six 30-ga11on drums approximately $\&$ months old had been stored in a shed at the Los Alamos Waste Disposal Site (Area G) and were readily avallable 
for study. A second group of six 30-gallon drums were retrleved from concrete casks in Trench "A" at Area G. These were approximately 9 years old. The third group of $\mathrm{s} 1 \mathrm{x} 30-\mathrm{ga} 1^{-}$ lon drums were recovered from similar casks in Trench "C" at Area G. These were approximately 39 months old. To recover these last two groups, $1 \mathrm{t}$ was necessary to remove $1.5 \mathrm{~m}$ of crushed tuff overburden ana the corrugated 1ron decking covering the casks (Flgure 1), and then locate by number the casks contalning the desired drums. Lids were sealed onto the casks with plastic cement. When this seal had bean broken (Figure 2), the casks' lids were removed, and the inside of the casks and the exposed drums carefully monttored for alpha sirface contamination and beta-gamma radiation (Figure 3). No contamination was found, and external radiation did not exceed a few mr at contact with the drums' walls. The Bobcat power shovel was then used to holst the desired drums out of the casks, and each was monitored again, examined for container integrity, and photographed (Figure 4). When the six drums for each trench had been recovered as described, they were hauled to a storage shed at Area $G$ to awalt further examination and testing. The drums shown th the pickup truck (F1gure 5) are the 39-month-old drums that had fust been removed from Trench "C." Note their clean, dry condition. All tags and stenciled labels were in excellent condition and completely legible. Note the contrast w1 th the 9-year-old drums (F1gure 6) that had been retrieved from Trench "A" and stored in the shed. Several of these drums had water standing on the $11 \mathrm{ds}$ when the casks were opened. It is believed that wet weather caused rain to puddle on the cask lids before the decking and tuff overburden hal been put in place, and the water was able to saturate the $11 \mathrm{ds}$ and trickle through. However, in spite of their apparent rusted condition, there was no serious corrosive damage. The integrity of the contalners was maintained as shown by later examination and wall-thickness measurement, and the labels and identifying marks generally were intact and legible. 

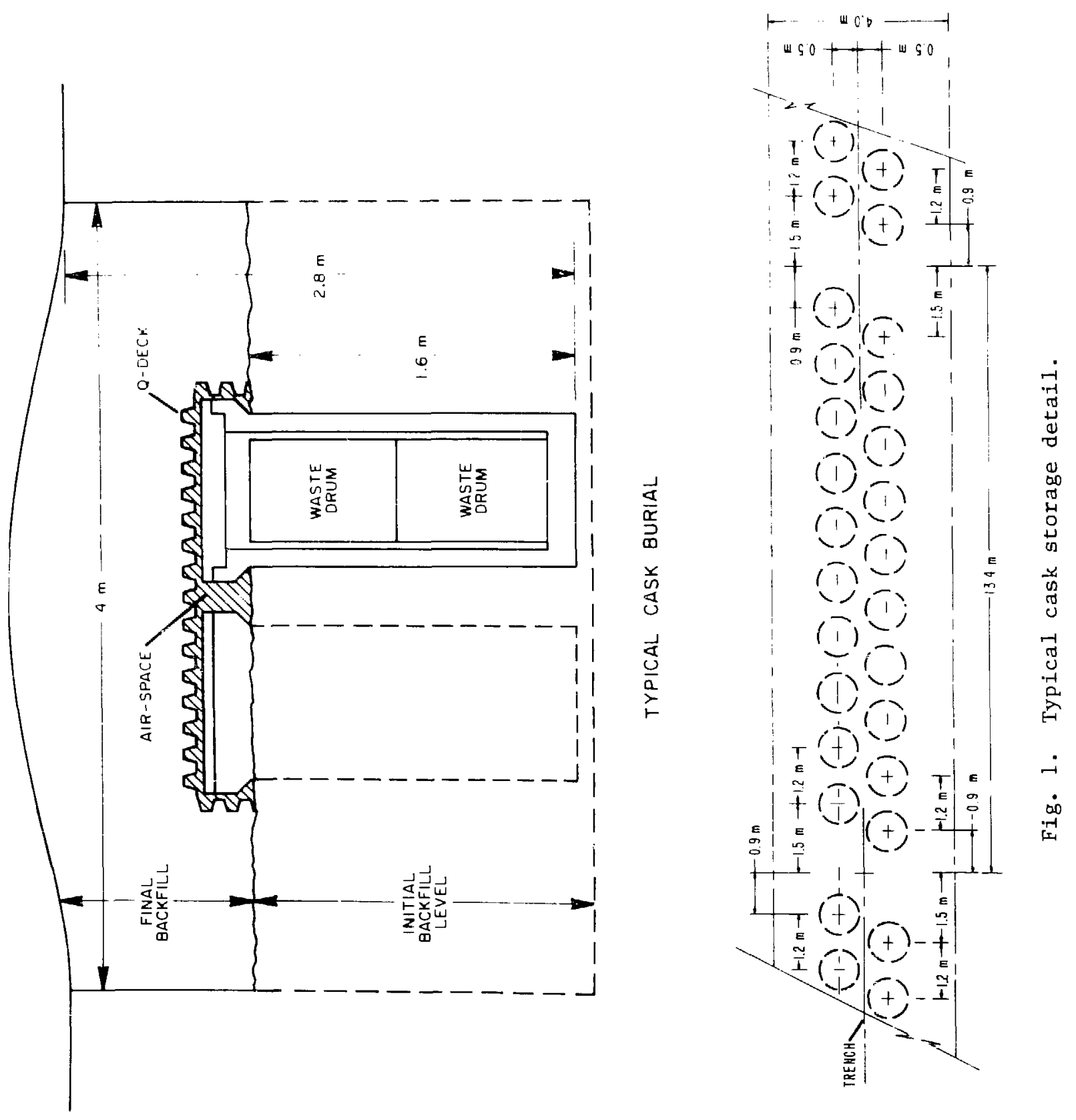


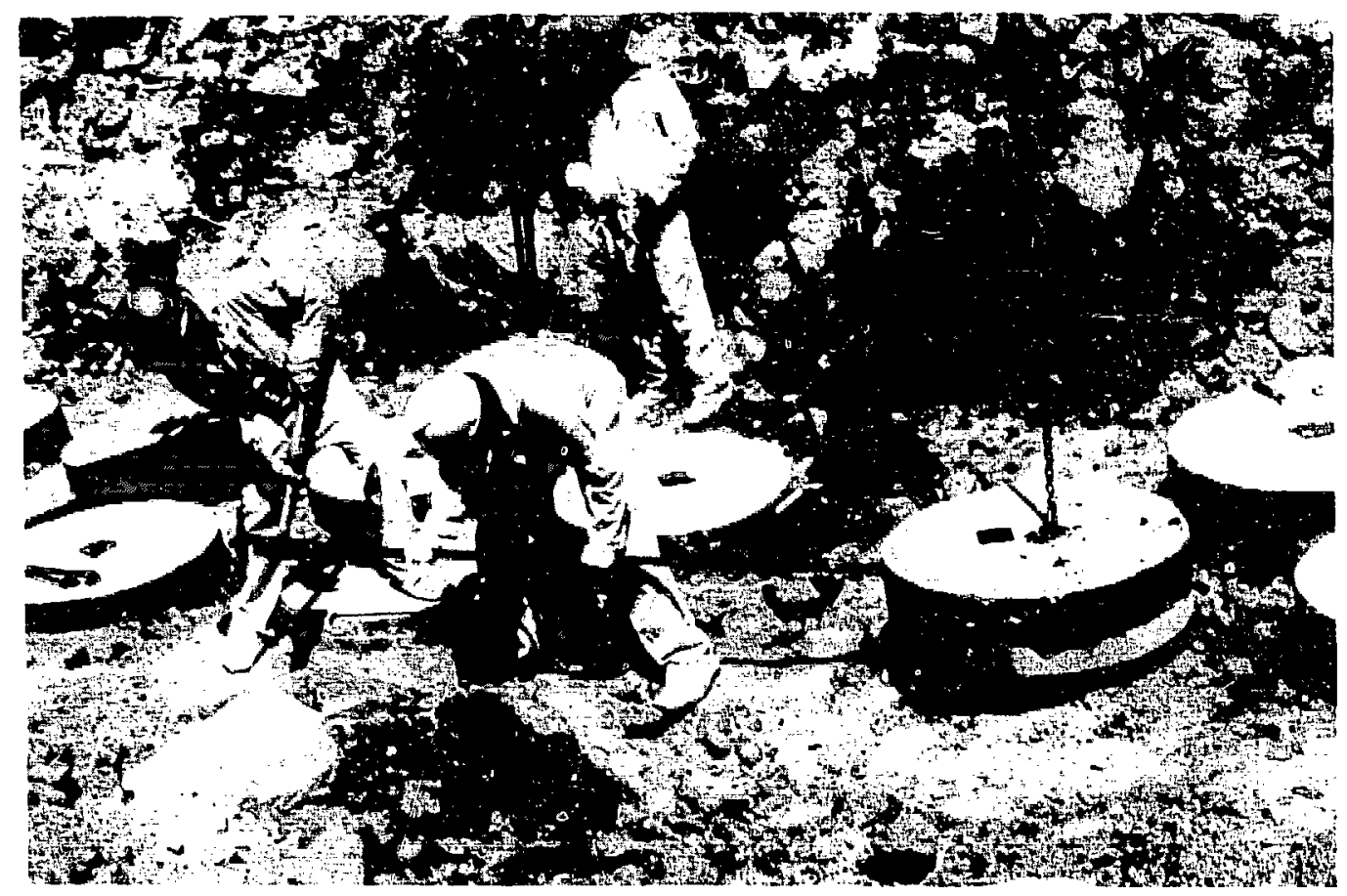

Fig. 2. Breaking the seal on the cask 1id.

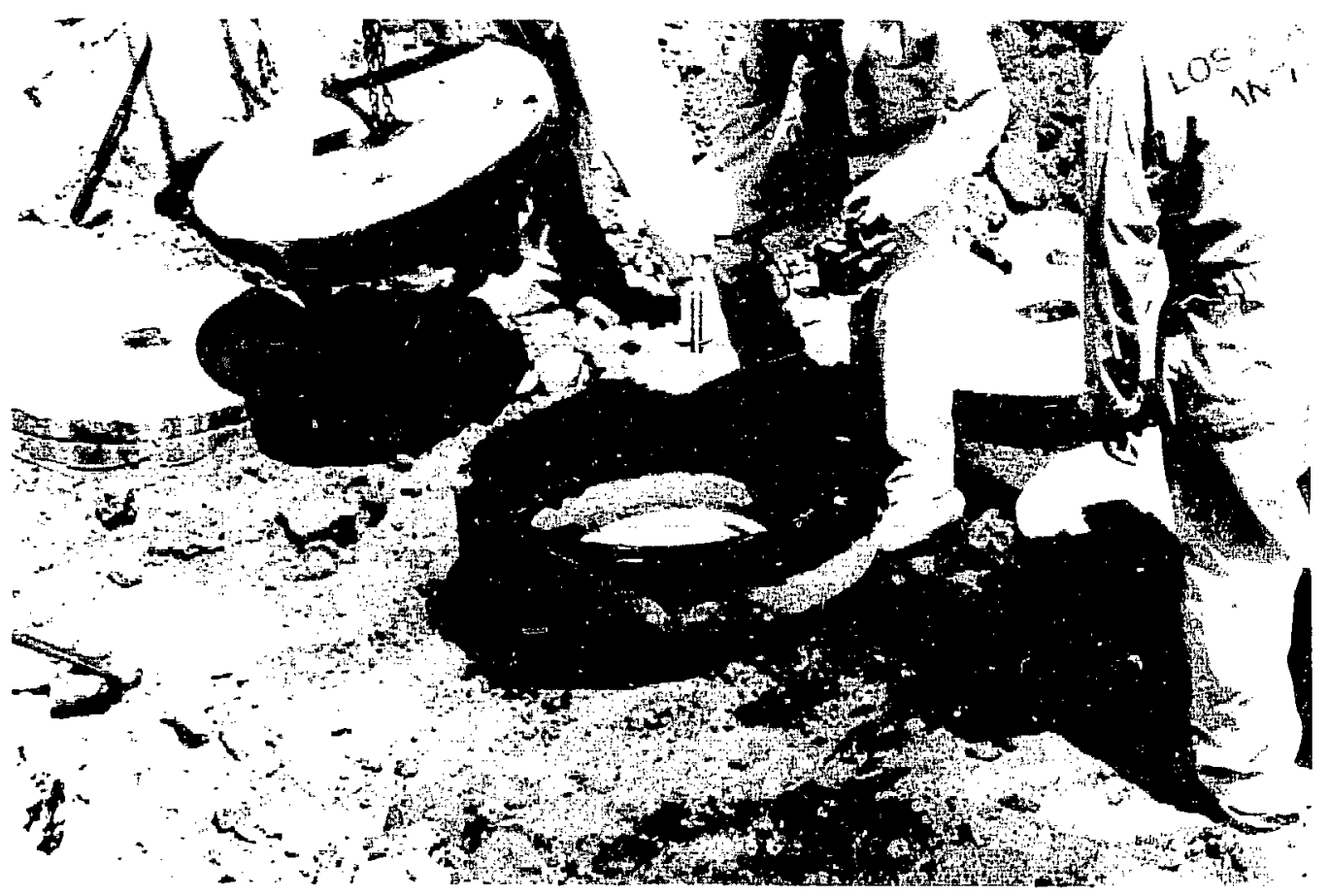

Fig. 3. With the lid removed, the inside of the cask and the drum are carefully monitored. 


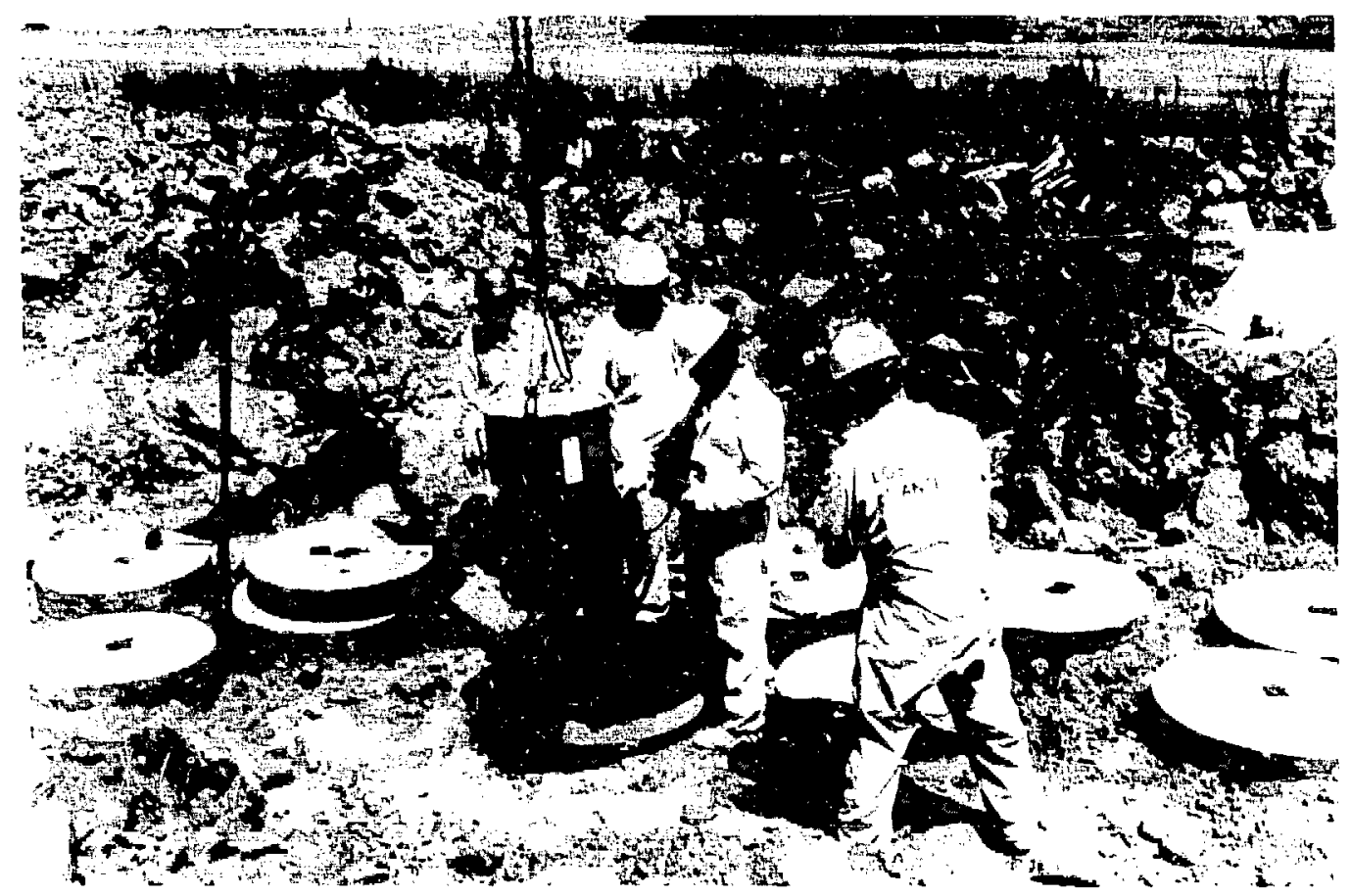

Fig. 4. The drum is removed from the cask, monitored, examined, and photographed.

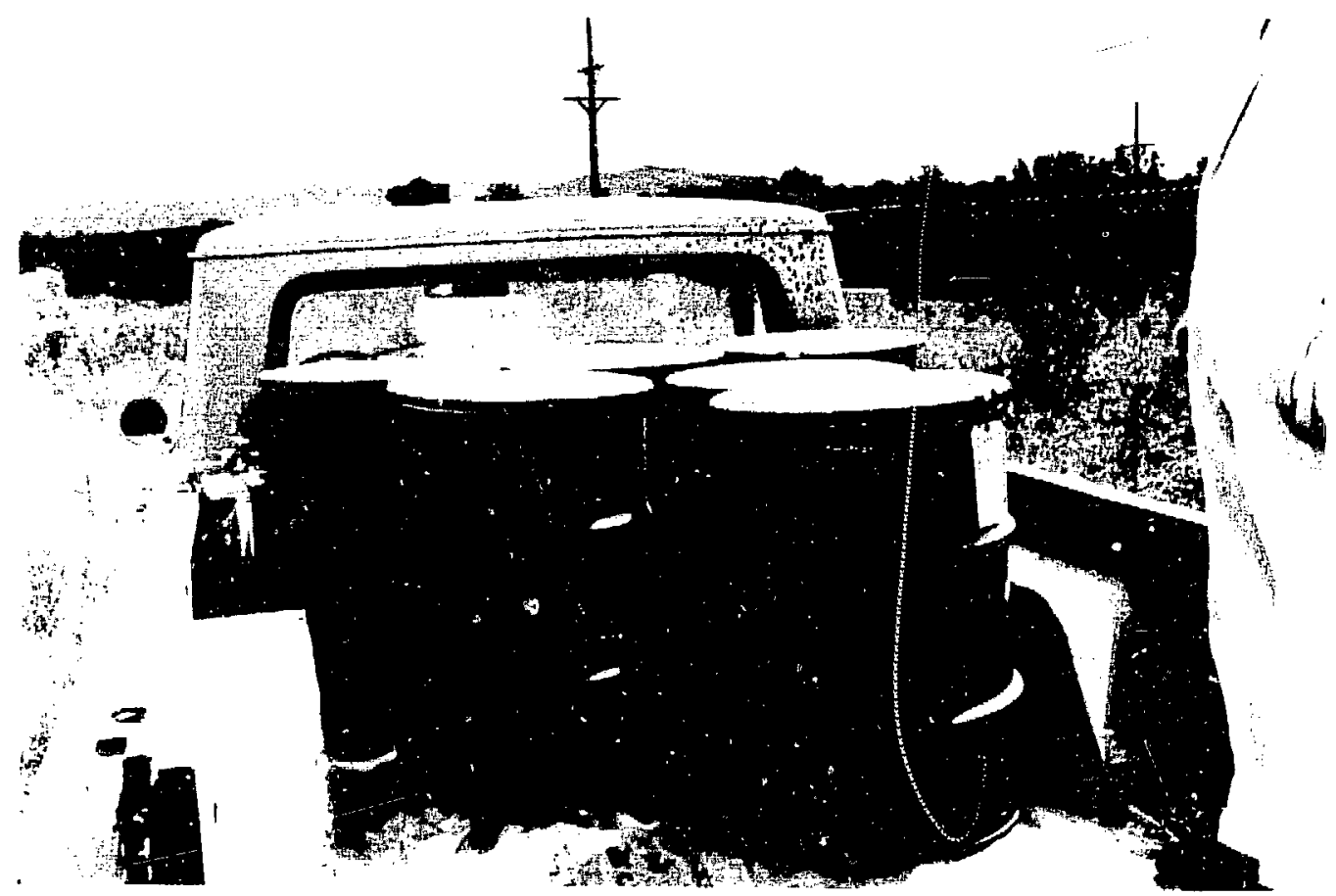

Fig. 5. Thirty-nine-month-old 30-gallon drums being moved to the storage shed at Area G. 
The 55-ga11on Drums - $239 \mathrm{Pu}-\mathrm{contam1nated}$ Waste

To obtain the 8-month-old $239 \mathrm{pu-contaminated} \mathrm{waste,} \mathrm{twenty-two}$ 55-gallon drums were removed from above-ground TRU Storage Pad No. 2 (F1gure 7) and moved inside the storage shed at Area G. Four additional 55-gallon drums 26 months old were recovered from Ce112, P1t 9 (F1gure 8), the first retrievable storage facility used at Los Alamos for TRU waste. Except for perlodic monttoring of alr in this cell, it had been closed from the summer of 1977 unt11 June 1981, when the decision was made to enter 1 and determine the condition of the 48 drums adjacent to the access shaft. In preparation for entering the cell, a 24-hour sample of the gaseous contents was drawn through the filter of a continuous alr monttor (CAM) to check for possible alrborne contamination. Only natural radon was detected. In addition, a sample of the gaseols mixture 1 n the cell was analyzed by mass spectrometry. The results are presented in Table I.

\section{TABLE I}

RESULTS OF ANALYSES OF GASEOUS MIXTURE IN CELL 2, PIT 9, AREA G

COMPONENT

Hydrogen

He 11 um

Carbon Monoxide

N 1 trogen

Methane

Oxygen

Argon

Carbon D $10 \times 1 \mathrm{de}$ $\frac{\text { JUNE } 1981}{(\operatorname{mol} \%)}$

0.7

$<0.1$

$<0.1$

79

$<0.1$

16

0.9 $\frac{\text { AUGUST } 1983}{(\operatorname{mo1} \%)}$

2
$<0.1$
$<0.1$
78
$<0.1$
19
0.9
0.1 


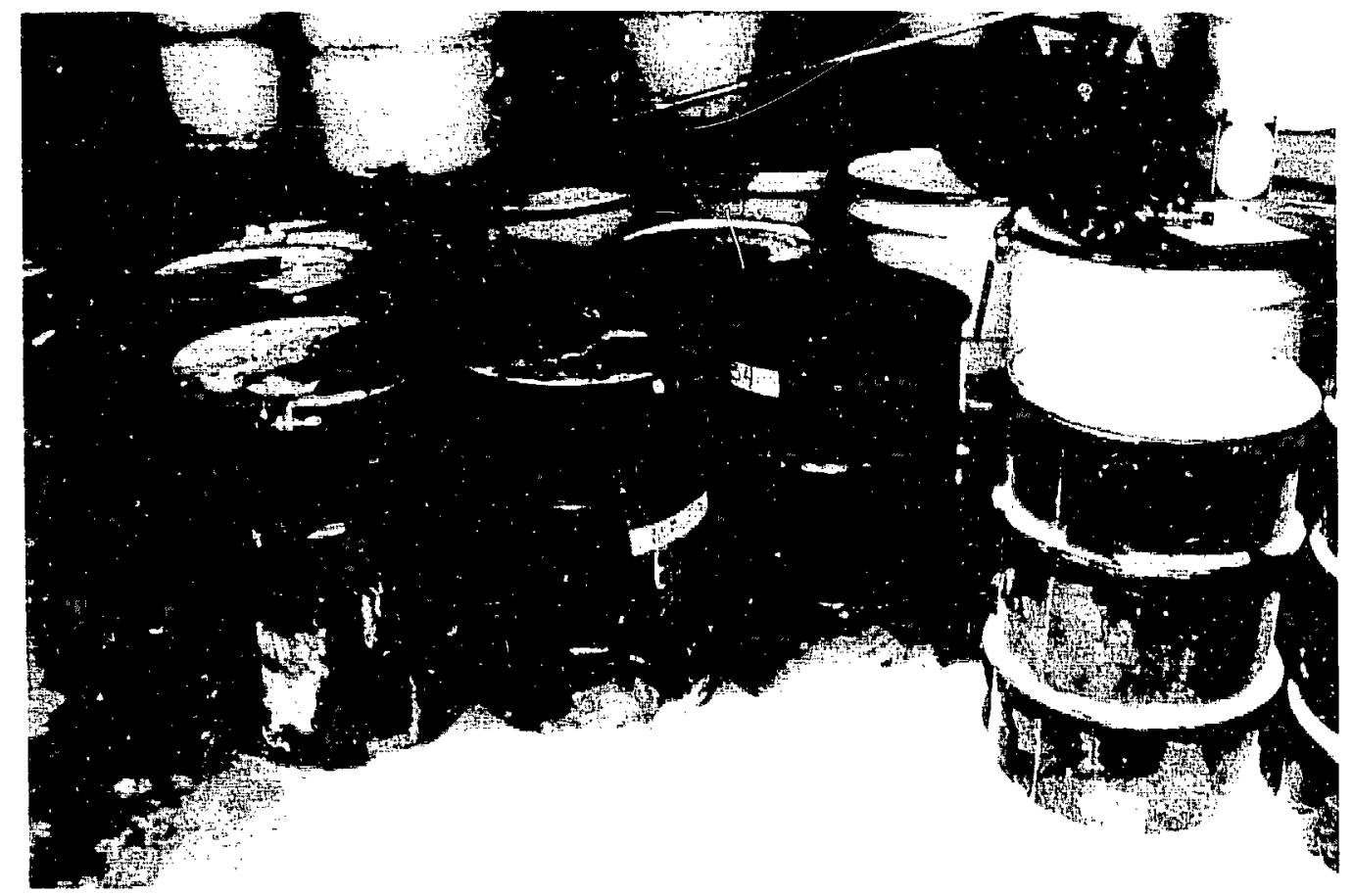

Fig. 6. Nine-year-old drums in shed awaiting sampling. Note the gas-sampling device at right.

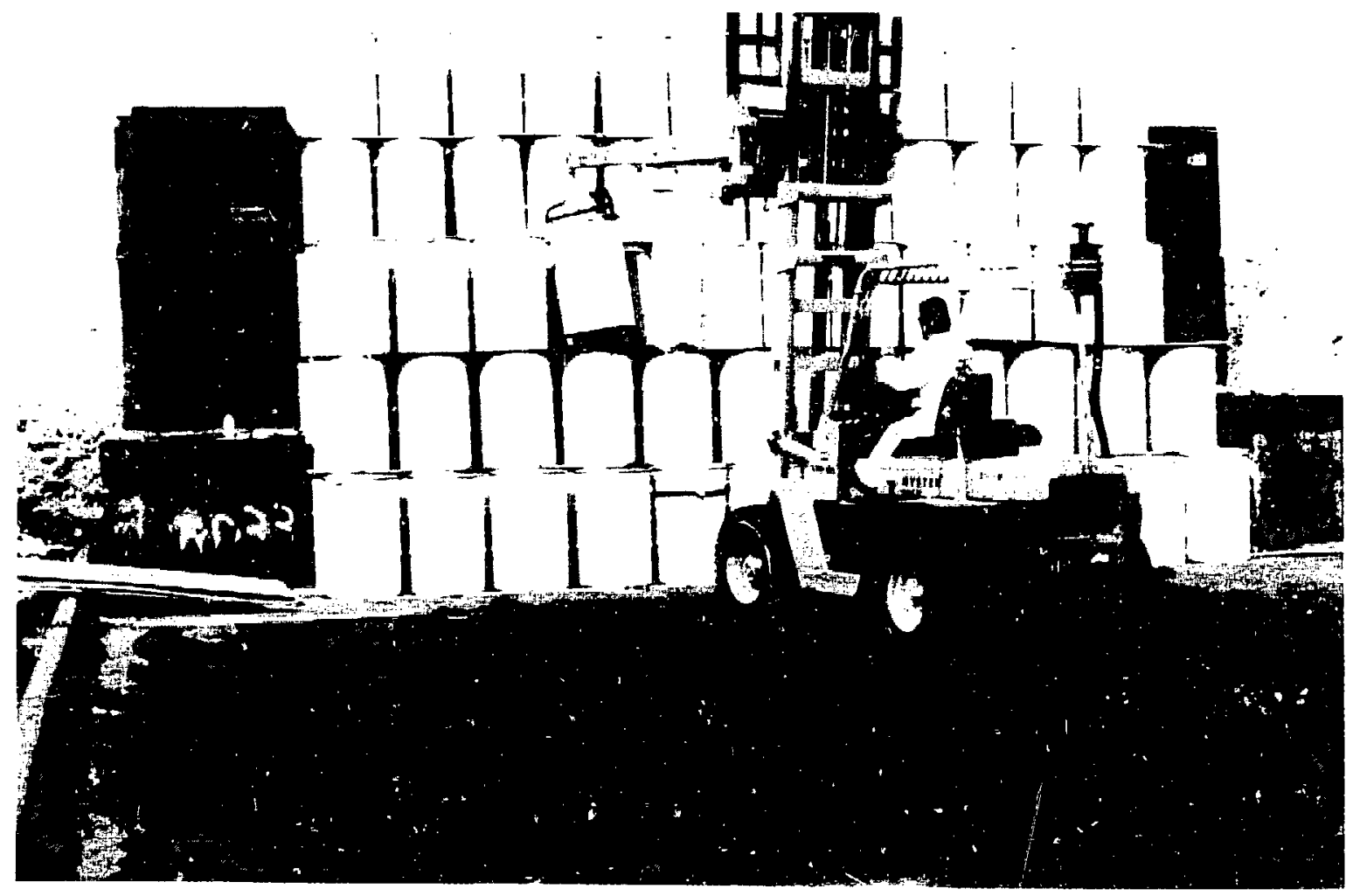

Fig. 7. Los Alamos TRU Storage Pad No. 2. 
A flexible 6-inch tube attached to a blewer was then lowered into the shaft, and the cell purged until normal atmosphere existed in the cell. Los Alamos personnei then entered the cel1 to determine the condition of ihe storage drums. They were dusty from finely divided tuff, and chere were a few small areas of lignt rust but no significant corrosion. Threeeighths-inch fire-retardant plywood had been used between the layers of drums to stabilize the stacks. Fire-retszat chemicals had bled from the plywood and were encrusted on the surface of the wood, and also on the bolt and ring closures of some drums. Chemlcal analysts verified the suspected identity of the encrustation; however, much of the material analyzed was finely divided tuff. The drums generally were in excellent condition, as seen in Figures 9, 10, and 11. Usually all stored drums were (and are) coated with a corrosion inhibltor (Texaco Compound L); however, the 48 drums emplaced around the access shaft in Cell 2 had several different coatings and were different types of drums. These variations were used for a comparison study of the corrosion reslstance of various materials under the storage conditions in the closed storage cell. While access to the shaft was available, four 55-galion drums were placed on the bottom, two coated with Compound L, and two left uncoated. The cell was then resealed.

When the TRU Waste-Sampling Program was inftiated In 1983 , it was declded to include the four drums from the bottom of the shaft in the group of drums to be evaluated. In reopening the cell, similar procedures were followed to those described for the 1981 operation. A tube attached to a CAM was lowered through one. of the 4-inch access pipes into cel12, and a 24hour air sample was pullped through the filter paper. The filter was assayed with an alpha courter and found to have 20,000 counts per minute. This radiation was judged to be radonthoron; the fllter was therefore allowed to decay for 24 hours. At the end of this time, the recount showed no activity. A sample of the gaseous mixture in Cell 2 was obtained 


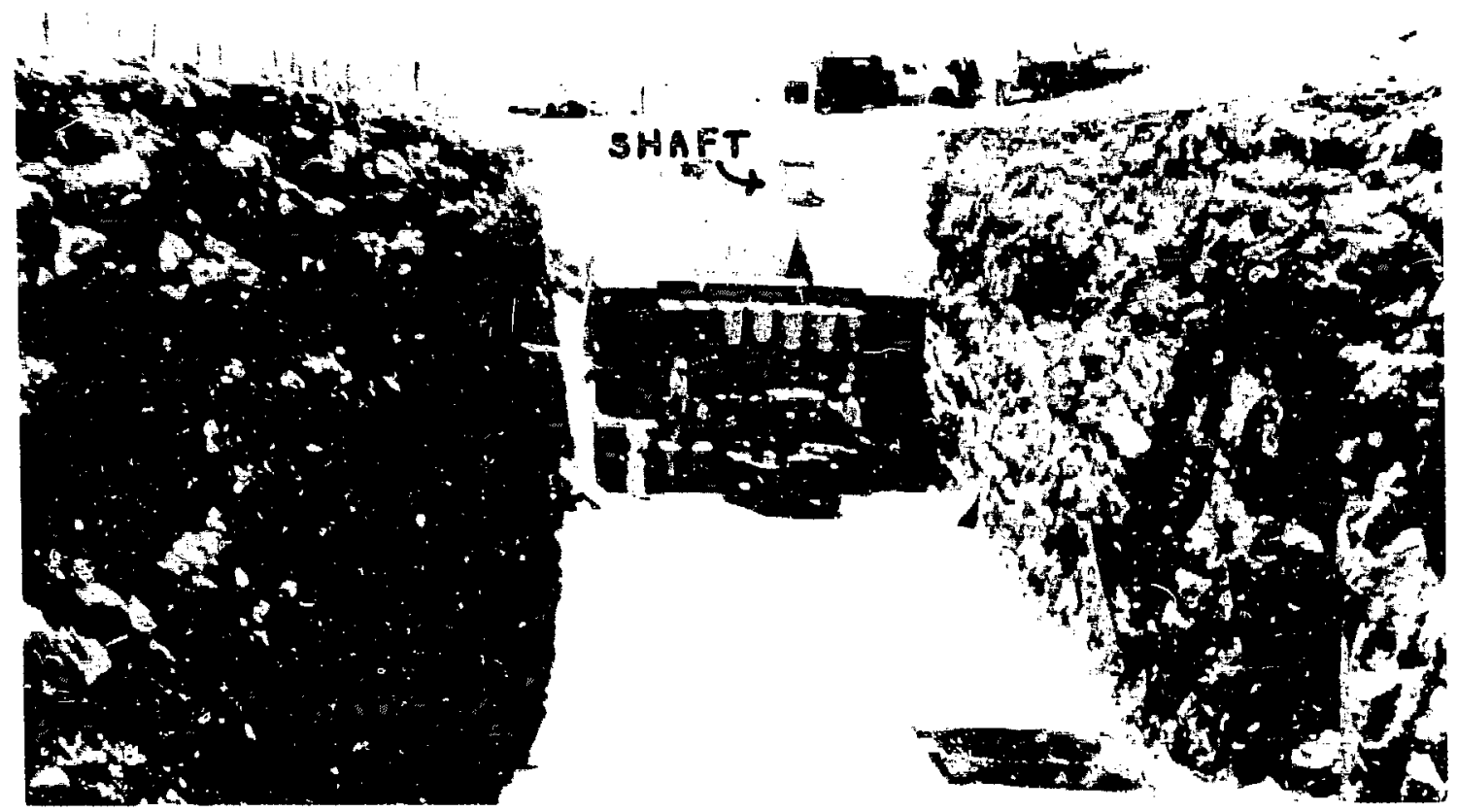

Fig. 8. Cel1 2 of Pit $y$, Los Alamos 'TRU Waste Sturage Facility, showing shaft arcess to cell.

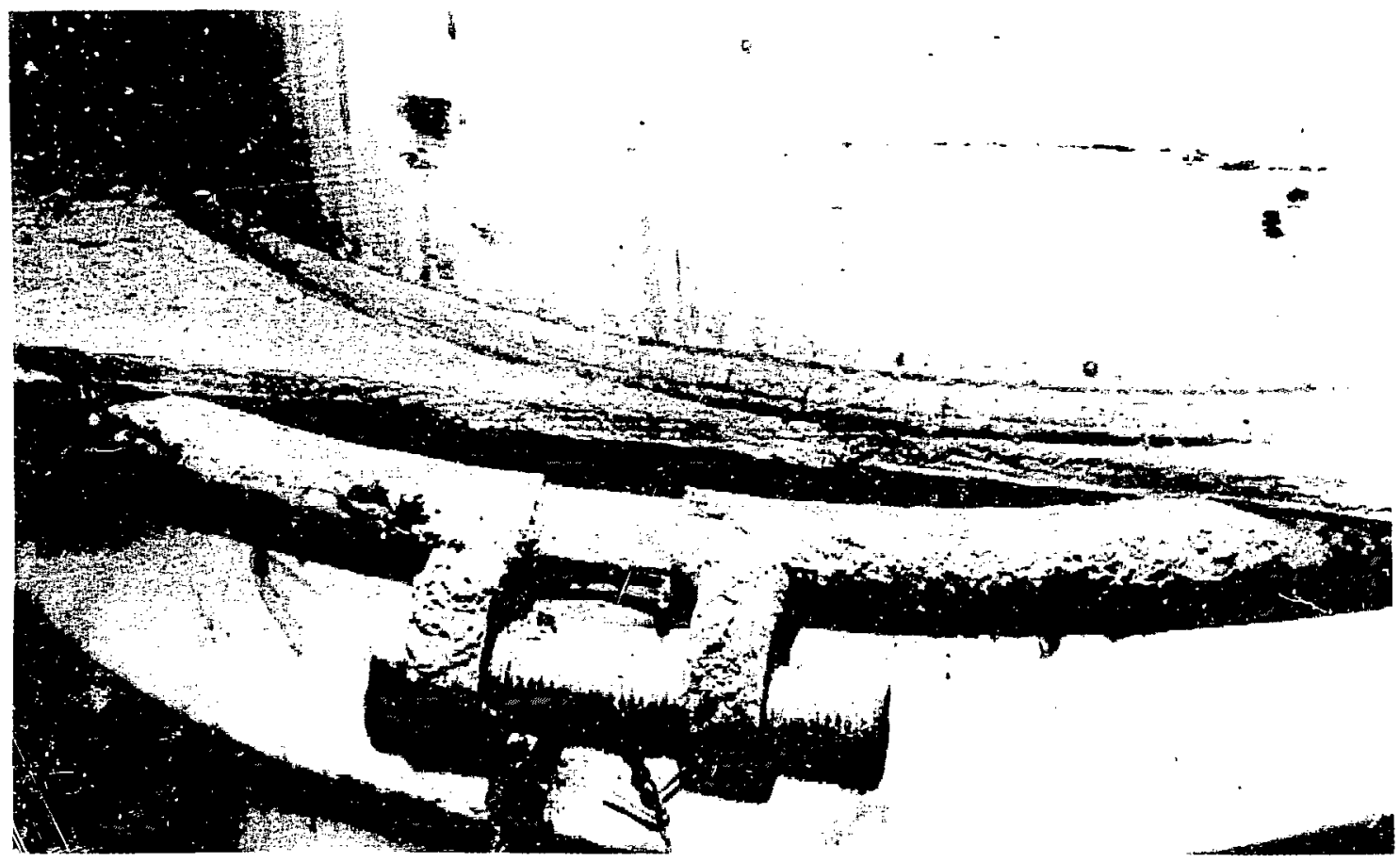

Fig. 9. Close-up showing finely divided tuff and some fireretardant chemicals that have bled from treated plywood and are collected on the sealing ring of a drum. 


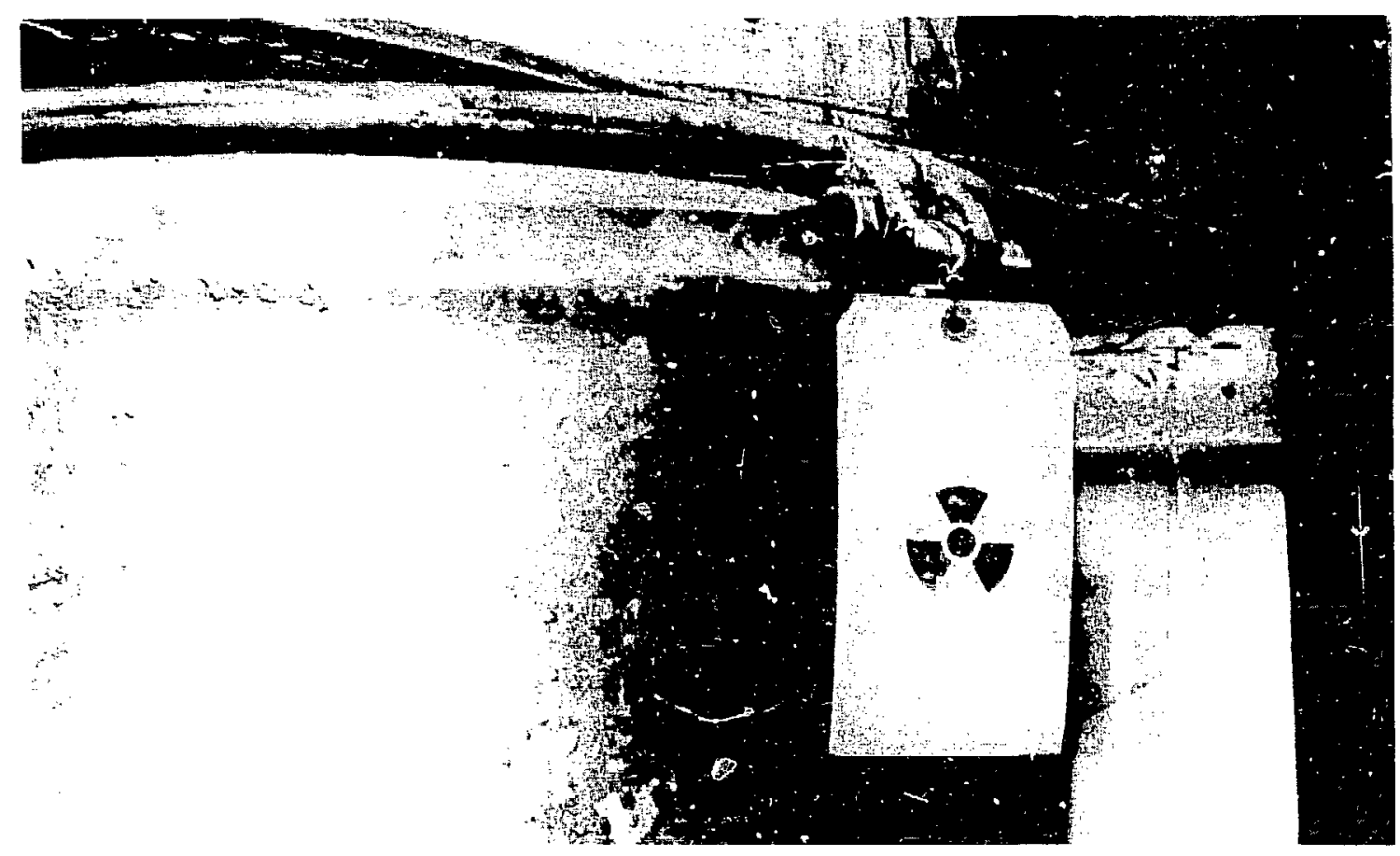

F1g. 10. A galvanized drum adjacent to the shaft in Ce11 2 (June 1981).

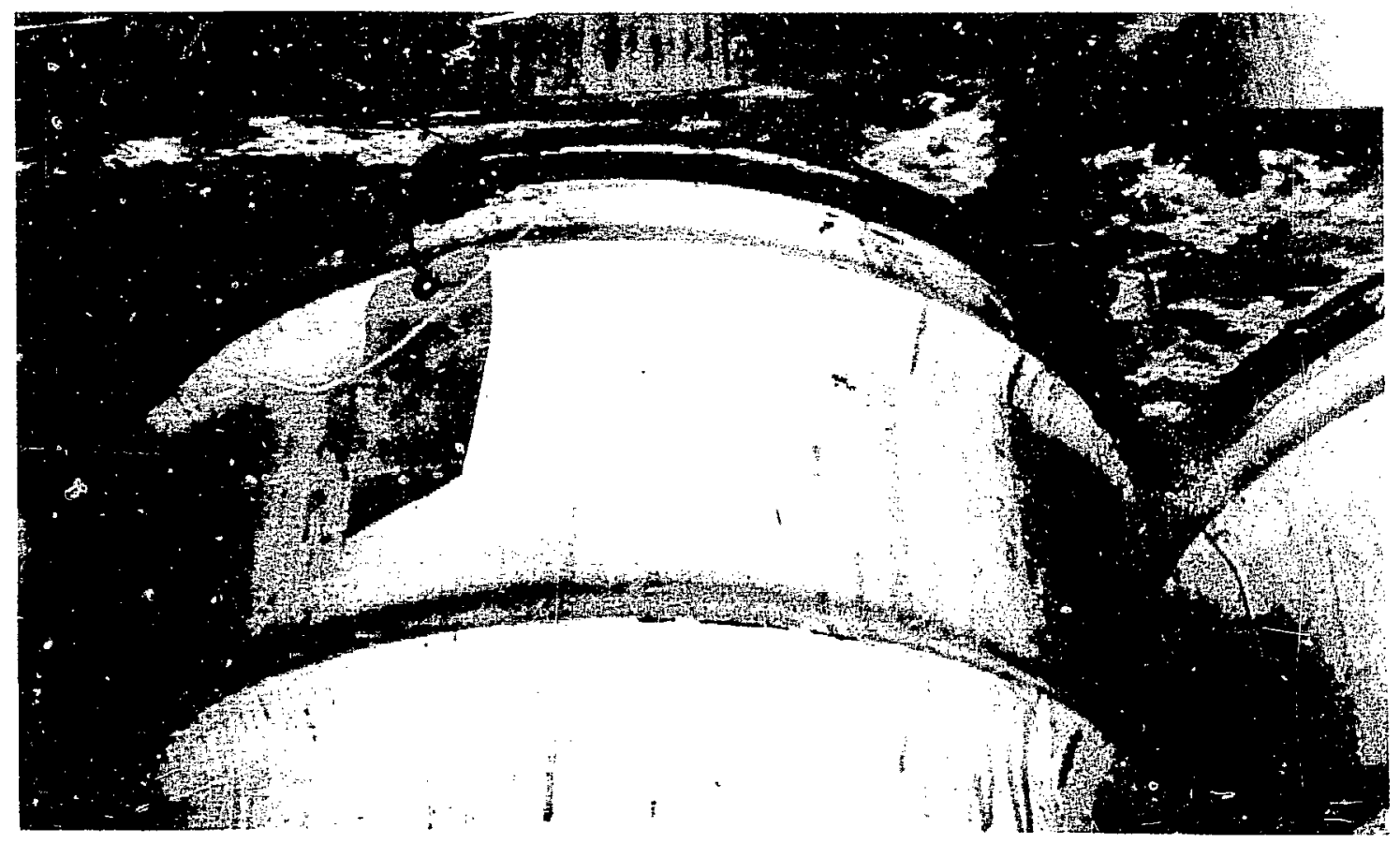

Fig. 11. Drums adjacent to shaft, coated with rust inhibitor

Texaco CPD L. Note fire-retardant bleeding out of plywood. 
and analyzed by mass spectroscopy. The results are shown in Table I for comparison with the earlier data. The detection of an elevated level of hydrogen, while not constituting a hazard, clearly indicates both the generation and diffusion of the gas from the waste containers. Over 3000 waste drums and 100 fiber-glass-reinforced polyester-coated plywood crates are stored in this pit. The air in the cell was purged, and the atmosphere checked with a Gas Tech Model 1641 Oxygen Detector. The oxygen had Increased to $21 \mathrm{~mol}$, and there were no combustible gases. Los Alamos staff members then entered the cell and examined the containers. All drums adjacent to the shaft were still in excellent condition, showing no deterioration. The four drums from the bottom of the shaft were removed, monitored, and piaced in the storage shed at Area G (Figures 12 and 13). There was no discernable difference in condition between coated and uncoated drums.

\section{GAS SAMPLING AND ANALYSIS}

Gas pressure was measured and a sample withdrawn for analysis from each drum by a sampling device developed at Los Alamos by A.1 Zerwekh (Figure 14).1 In a11, efghteen 30-gallon drums concaining $238_{\mathrm{P} u-c o n t a m i n a t e d}$ waste and twenty 55-galion drums containing 239 pu-contaminated waste were sampled, and the samples vere analyzed by the Los Alamos Analytical Chemistry (CHM-1) Mass Spectrometry Section. The device is sealed onto the side of the drum near the top with a gas-tight seal, and a small hole is drilled through the drum wall. A pressure gauge on the sample immediately registers the prossure, if any, in the drum. All of the Los Alamos drums were at atmospheric pressure. This pressure was expected because the drums are sealed with a sponga-rubber gasket that renders them 1iquidand particle-tight, but allows gas in excess of atmospherfc pressure to diffuse out of the container. Next, an evacuated 1-liter sample bulb was attached to the sampler and the valve 


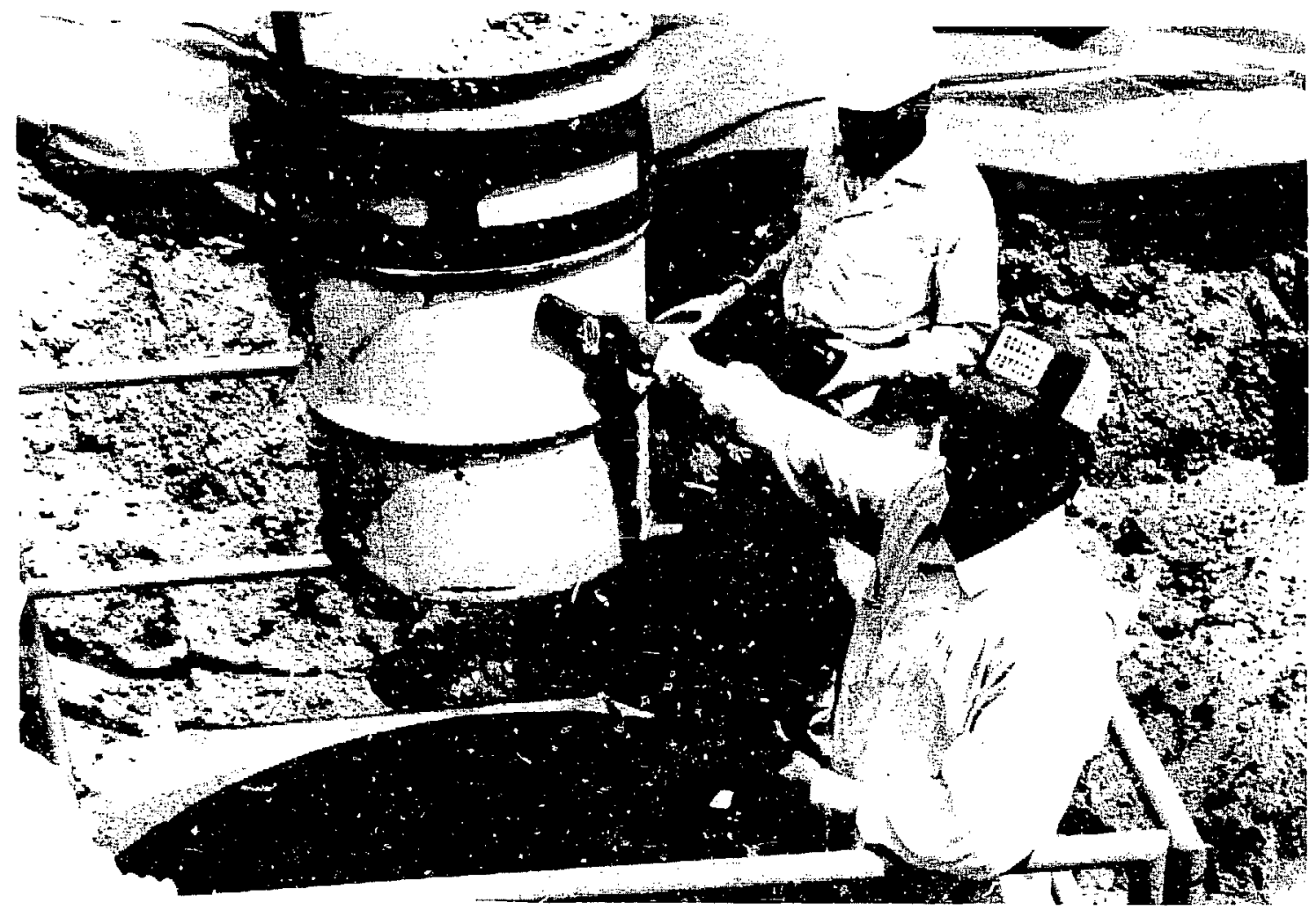

Fig. 12. Uncoated ${ }^{239} \mathrm{Pu}$-contaminated waste drum being retrieved from bottom of shaft, Cell 2 . 


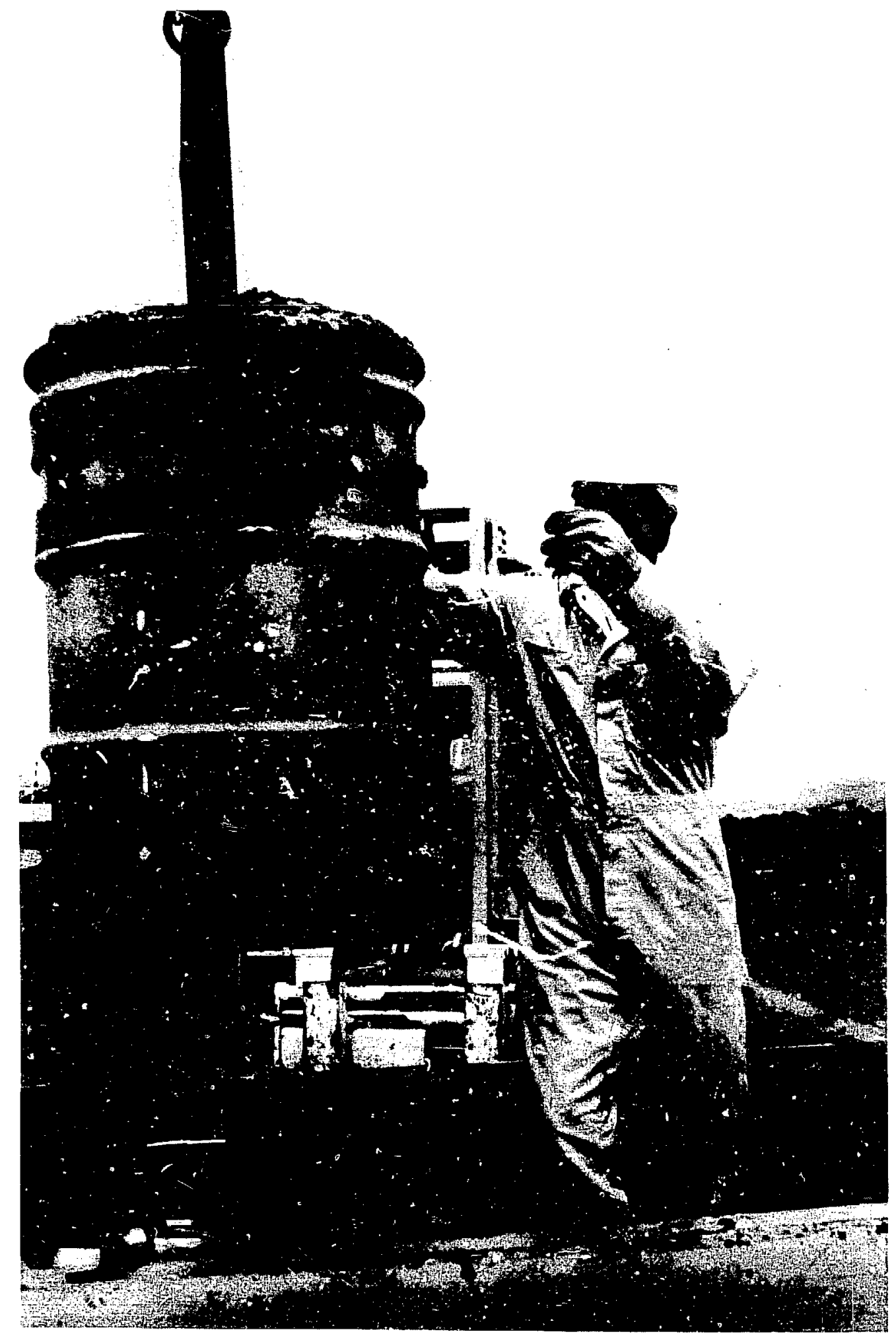

Fig. 13. Compound-L-coated drum has been monitored, was found uncontaminated, and is on its way to the shed for gas sampling. 
opened. Withdrawing this sample purges the equipment with a portion of the gaseous contents of the drum. This sample is discarded, and a second evacuated sample bulb is employed lmmediately to collect the sample to be analyzed by the mass spectrometer (F1gure 15).

After the gas samples had been removed from the drum, the hole was sealed with silicone cement, a ftber washer, and a sheetmetal screw.

Each day, before any samples were analyzed, a rew instrument sensitivity factor was determined for each gas of interest. This factor was determined by measuring the electrical response of the lnstrinent to a known amount of each gas. Dally determation of the sensitivity factors is standard procedure for Loe Alamos mass spectrometric work and avoids reliance on a secondary stariard. The gases included in the daily calibration and the approximate sensitivity factor for each were: hydrogen, $41 \mathrm{mV} / \mathrm{\mu m}$; hellum, $15 \mathrm{mV} / \mu \mathrm{m}$; carbon moroxide, $2 \mathrm{mV} / \mu \mathrm{m}$; nitrogen, $7 \mathrm{mV} / \mu \mathrm{m}$; methane, $82 \mathrm{mV} / \mu \mathrm{m}$ : oxygen, $68 \mathrm{mV} / \mu \mathrm{m}$; argon $95 \mathrm{mV} / \mu \mathrm{m}$; and carbon d1oxide, $74 \mathrm{mV} / \mu \mathrm{m}$.

A certified gas sample was supplied to Los Alamos by EG $\& G$ Idaho. After the daliy sensitivity factors were determined, the sample was analyzed and results reported by telephone to Tom Clements at EG\&G Idaho. (Figure 16 is a copy of the analytical report.) The results of the analysis were pronounced acceptable, and Los Alamus proceeded with the analyses of the gaseous contents of the waste drums. Table I. contalns results of the analyses of the standard gas sample as determined throughout the experimental period.

Gas-sampling analytical results are shown in Tables III and IV. The results Indicate that there should be no problem with 


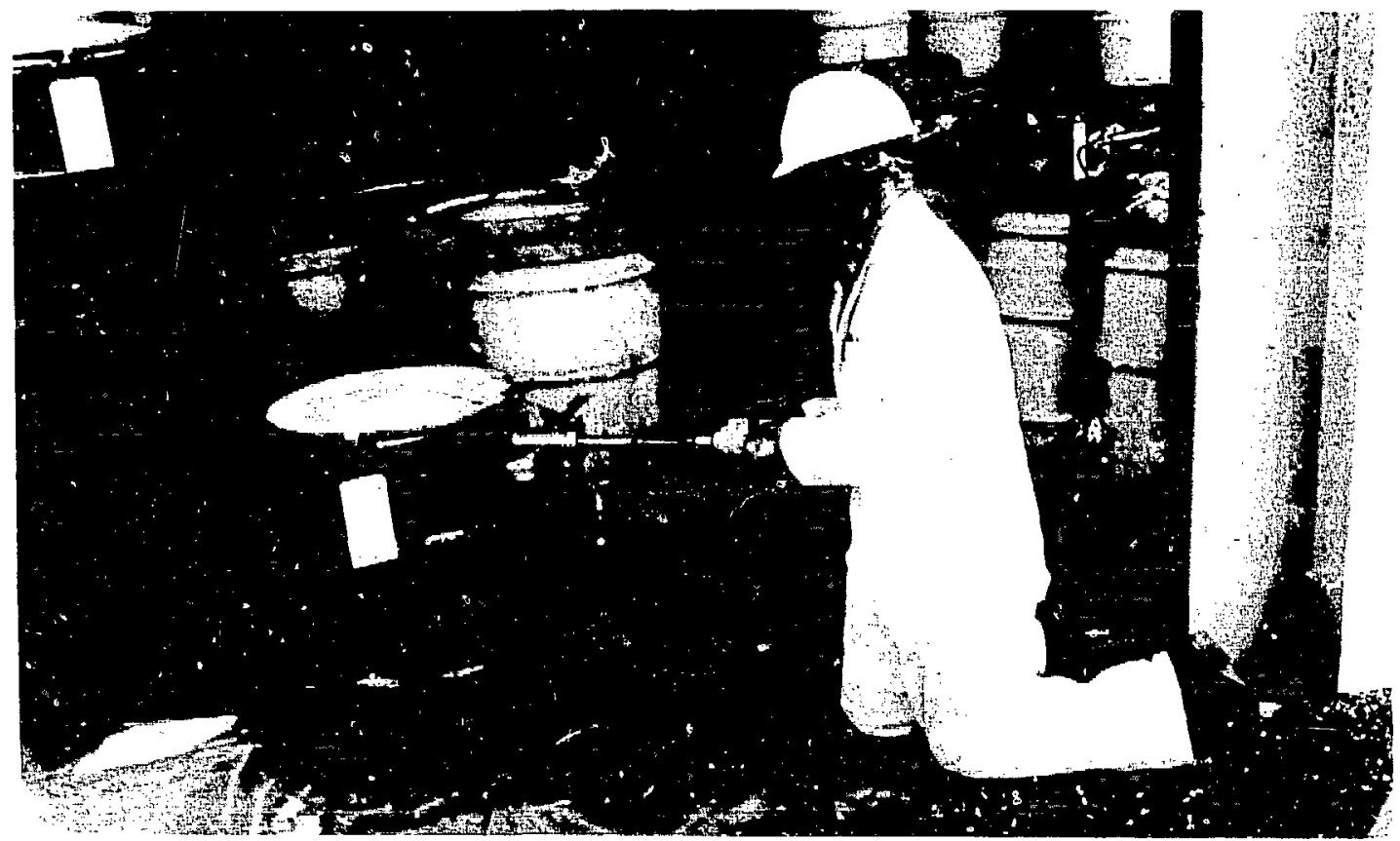

Fig. 14. ihecking a 30-gallon drum for gas pressure, and preparing to remove a gas sample.

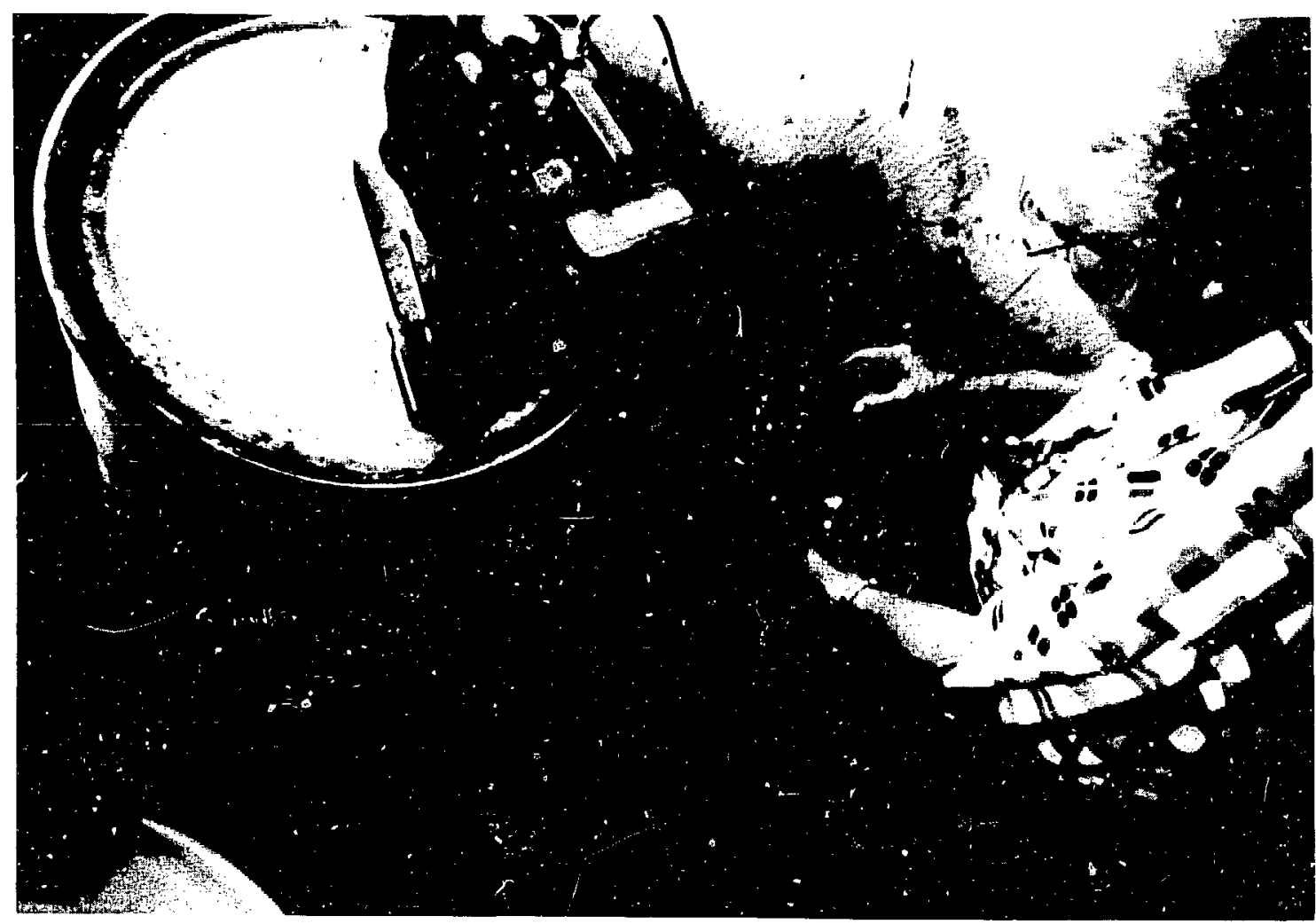

Fig. 15. Withórawing a gas sample into a 1-1iter bulb. 
the shipment of $239 \mathrm{Pu}$-contaminated waste; the naximum $\mathrm{H}_{2}$ content of these drums was $1.4 \mathrm{mo} 1 \%$. However, three of the s $1 x$ $238 \mathrm{pu}$ drums of 8 -month-old waste contalned a potentially hazardous gas mixture that could explode 1 f exposed to a spark or flame.

\section{Analytical Chemistry Report}

Samp1e No.: 28126

Date Reporied: $19-M A R-84$

Submitting Group: HSE-7 Submitter: VANCE Form B Code: A4ll

Sample Identification: DCV EGGl Date Submitted: 1-AUG-83

Sample Description: STANDARD GAS FOR EG\&G DECOMPOS

Anslyses Requesred: $\mathrm{H} 2, \mathrm{CC}, \mathrm{CO} 2, \mathrm{CH} 4,02, \mathrm{~N} 2, \mathrm{NOx}$ Submittar:s Comments:

ANALYTICAL RESULTS

Analytical Resu1ts

2.5 MOL \% H 2

1. 2 MOL\% CO

$12.0 \mathrm{MOL} \% \mathrm{CO} 2$

<0.1 MOL\% CH4

18.0 MOL\% 02

66.3 MOL\% N 2

\section{Analyst (s)}

ARCHULETA, NK

same

same

same

same

same
Notebook Page(s)

19964

62

same

same

same.

same

same

(*) $\%=$ G/100 G Sample anc $2 \mathrm{QM}=\mathrm{UG} / \mathrm{G}$ Sample

COMMENTS: NO OTHER SIGP IFICANT GASEOUS COMPONENTS DETECTED.

Certified by P. T. Cunningham

F1gure 16. Certified gas sample. 
TABLE II

ANALYSES OF STANDARD GAS SAMPLE

MOL\% OF CONSTITUENTS

\begin{tabular}{|c|c|c|c|c|c|c|c|c|c|}
\hline DATE & & $\underline{\mathrm{H}}_{2}$ & $\underline{\mathrm{He}}$ & CO & $\underline{\mathrm{N}}_{2}$ & $\underline{\mathrm{CH}}_{1}$ & $\underline{o}_{2}$ & $\underline{A r}$ & $\underline{\mathrm{CO}}_{2}$ \\
\hline $12-29-83$ & & 2.6 & $<0.1$ & 1,6 & 65.9 & $<0.1$ & 18.5 & $<0.1$ & 11.4 \\
\hline $1-20-84$ & & Canc & 1 ed & & & & & & \\
\hline $2-21-84$ & & 3.0 & $<0.1$ & 1.4 & 65.3 & $<0.1$ & 18.7 & $<0.1$ & 11.7 \\
\hline $3-27-84$ & & 3.0 & $<0.1$ & 1.0 & 65.8 & $<0.1$ & 18.6 & $<0.1$ & 11.6 \\
\hline $3-30-84$ & & 2.3 & $<0.1$ & 0.4 & 66.7 & $<0.1$ & 18.8 & $<0.1$ & 11.8 \\
\hline $4-10-84$ & & 3.6 & $<0,1$ & 1.4 & 65.0 & $<0.1$ & 18.6 & $<0 .$. & $: 1.4$ \\
\hline $5-4-84$ & & 2.7 & $<0.1$ & 1.0 & 65.6 & $<0.1$ & 19.0 & $<0.1$ & 11.7 \\
\hline $5-30-84$ & & 1.9 & $<0,1$ & 1.1 & 66.3 & $<0.1$ & 19.0 & $<0.1$ & 11.7 \\
\hline $6-14-84$ & & 2.4 & $<0.1$ & 0.9 & 65.9 & $<0.1$ & 19.0 & $<0.1$ & 11.8 \\
\hline $7-10-84$ & & 2.5 & $<0.1$ & 0.5 & бó. 1 & $<0, \ddot{i}$ & 19.1 & $<0.1$ & 11.8 \\
\hline $8-3-84$ & & 2.5 & $\leq 0.1$ & $2.9 *$ & 64.9 & $\leq 0.1$ & 18.4 & $\leq 0.1$ & 11.3 \\
\hline & 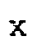 & .65 & & .03 & & & & & \\
\hline & 0 & \pm .46 & & \pm .40 & \pm .57 & & \pm .25 & & $\because y$ \\
\hline
\end{tabular}

Foutler not Included in calculation. 
TABLE III

238 P D DRUMS SAMPLED FOR GAS ANALYSIS

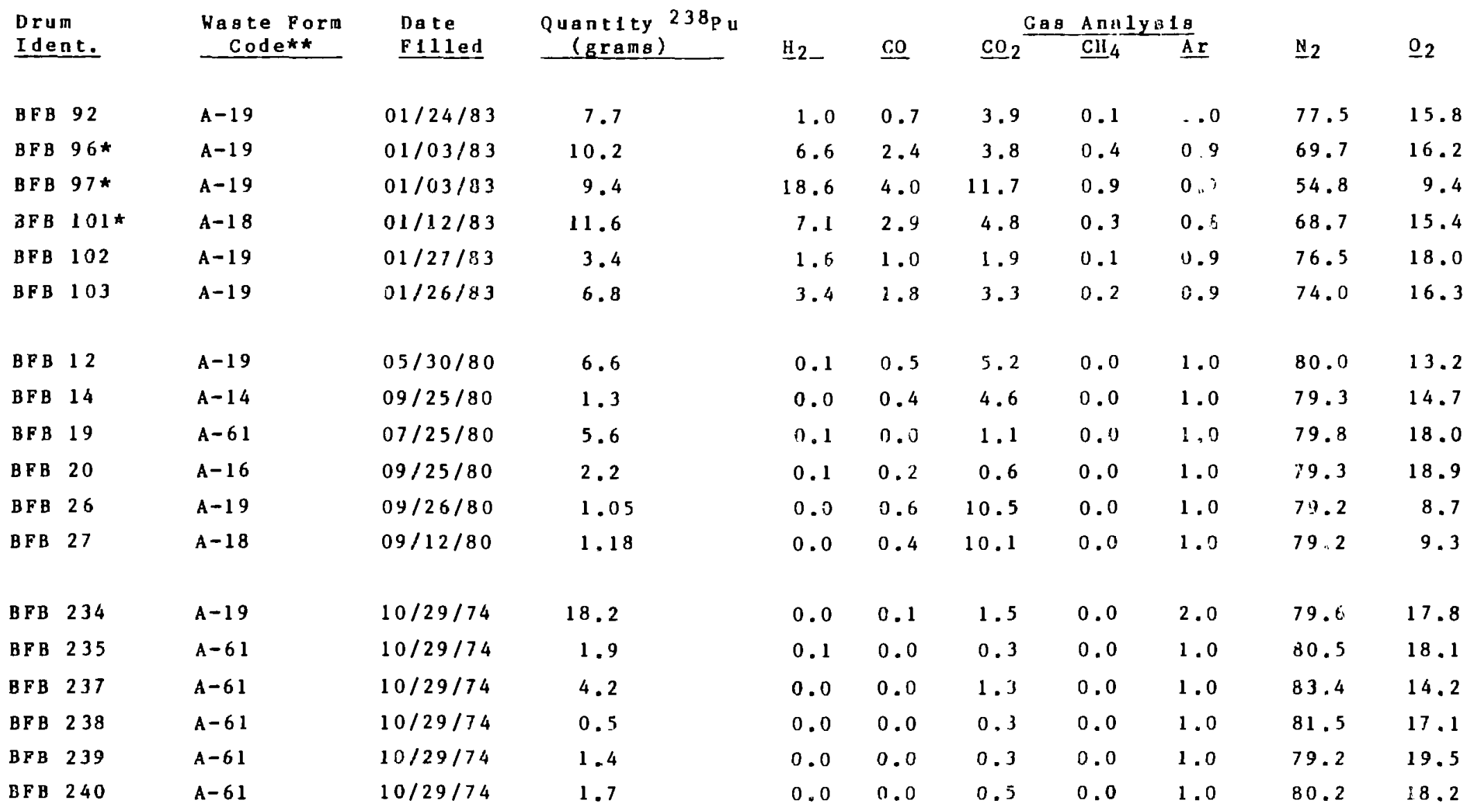

*These drums are probably potentially explosive if gaseous contents are exposed to opark bource. * See Appendix 1 for Identification of Waste Farm Codes. 
239 PU DRUMS SAMPLED FOR GAS ANALYSIS

\begin{tabular}{|c|c|c|c|c|c|c|c|c|c|c|}
\hline Drum & Waste Form & Date & Quantity $239 \mathrm{eu}$ & & & $\underline{G} \underline{B}$ & Analy & & & \\
\hline Ident. & Code & F11 ed & (grams) & $\underline{H}_{2}$ & $\underline{\mathrm{co}}$ & $\underline{\mathrm{CO}}{ }_{2}$ & $\underline{\mathrm{CH}}_{4}$ & A 5 & $\underline{N}_{2}$ & $\underline{0}_{2}$ \\
\hline 0007060 & $A-18$ & $02 / 14 / 83$ & 3.3 & 0.8 & 0.9 & 4.0 & 0.0 & 1.0 & 79.2 & 14.1 \\
\hline 0007226 & $A-18$ & $02 / 14 / 83$ & 0.4 & 0.1 & 1.0 & 2.9 & 0.0 & 1.0 & 78.8 & 16.2 \\
\hline $0010108 *$ & $A-25$ & $07 / 02 / 81$ & $80^{a}$ & 0.0 & 0.3 & 0.5 & 0.0 & 1.0 & 78.6 & 19.8 \\
\hline 0010362 & $A-18$ & $01 / 19 / 83$ & 26.2 & 0.2 & 0.0 & 0.5 & 0.0 & 1.0 & 78.9 & 17.6 \\
\hline 0010405 & $A-47$ & $01 / 25 / 83$ & 191 & 0.1 & 0.0 & 0.3 & 0.0 & 1.0 & 78.4 & 20.1 \\
\hline 0010411 & $A-25$ & $01 / 27 / 83$ & 186 & 0.1 & 0.0 & 0.3 & 0.0 & 1.0 & 78.6 & 19.9 \\
\hline 0010435 & $A-61$ & $01 / 20 / 83$ & 38 & 0.2 & 0.0 & 0.5 & 0.0 & 1.0 & 78.8 & 19.5 \\
\hline 0010494 & $A-47$ & $01 / 19 / 83$ & 198 & 0.1 & 0.2 & 0.6 & 0.0 & 1.0 & 78.7 & 19.5 \\
\hline 0010605 & $A-18$ & $01 / 25 / 83$ & 122 & 1.4 & 0.0 & 3.6 & 0.0 & 0.9 & 77.4 & 16.7 \\
\hline $00: 0 f-45$ & $A-61$ & $01 / 26 / 83$ & 108.3 & 0.1 & 0.1 & 0.7 & 0.0 & 1.0 & 76.6 & 19.4 \\
\hline $00107 ; 3$ & $A-16$ & $01 / 26 / 83$ & 46 & 0.1 & 0.0 & 2.1 & 0.0 & 2.0 & 82.4 & 14.4 \\
\hline $0010756 \#$ & $A-19$ & $06 / 15 / 81$ & Note $e^{b}$ & 0.0 & 0.2 & 0.7 & 0.0 & 1.0 & 78.2 & 19.9 \\
\hline 0010761 & $A=14$ & $01 / 26 / 83$ & 0.47 & 0.0 & 0.2 & 1.6 & 0.0 & 1.0 & 78.9 & 18.3 \\
\hline 0010773 & $A-19$ & $01 / 26 / 83$ & 0.1 & 0.0 & 0.1 & 0.8 & 0.0 & 1.0 & 78.6 & 19.4 \\
\hline $0010775 *$ & $A-60$ & $06 / 02 / 81$ & 27.9 & 0.0 & 0.0 & 0.7 & 0.0 & 1.0 & 78.7 & 19.6 \\
\hline $0010925 *$ & $A-25$ & $06 / 24 / 81$ & 32.4 & 0.5 & 0.1 & 0.3 & 0.0 & 1.0 & 76.9 & 21.2 \\
\hline 0012223 & $A-16$ & $01 / 27 / 83$ & 63 & 1.2 & 0.3 & 6.3 & 0.0 & 1.0 & 79.0 & 12.2 \\
\hline 0012395 & $A-25$ & $01 / 19 / 83$ & 185 & 0.2 & 0.0 & 4.9 & 0.0 & 0.9 & 80.1 & 13.7 \\
\hline 0012432 & $A-27$ & $01 / 27 / 83$ & 75.95 & 0.1 & 0.0 & 12.3 & 0.0 & 0.8 & 73.8 & 12.9 \\
\hline 0012433 & $A-27$ & $01 / 27 / 83$ & 7.93 & 0.3 & 0.3 & 0.8 & 0.0 & 1.0 & 80.9 & 17.0 \\
\hline
\end{tabular}

*Drumb removed fram shaft in cell 2, Pit 9 .

* See Appendix l for Identification of Wate Form Coder.

aTh1a drum alao containg $0.3 \mathrm{gram} 238_{\mathrm{Pu}}$.

bThis drum containg $244 \mathrm{Am}, 248 \mathrm{Cf}$, and $249 \mathrm{Bk}$; no gram amounts apecified. 
VOID VOLUMES AND G VALUES

It was not possible to measure vold volumes by pressure and volume relationships nor meaningful to calculate g values in Los Alamos waste drums because the drums are not required to be sealed gas-tight. They are sealed with 0.5-1nch sponge-rubber gaskets, and the closure rings torqued to approximately 40 ftlbs, which renders them 11 quid- and particulate-tight but not gas-tight. The gaseous contents of the drums are therefore at atmospheric pressure. Any gases generated in excess of approximately 580 torr diffuse harmlessly into the atmosphere. The escaplng gases have never been found to be radioactive. For this reason, the vold volumes were estimated by radiography and by visual examination when the drums were opened. The estimated vold volumes obtalned by these two methods and raported on the summary sheets (Appendix 2) are actually estimates of filling efficlency. Because many of these drums are filled with organic materials, it was suspected that the vold volumes would actually be considerably higher. Using the weights and densities of the waste matezials, the vold volumes for 10 drums were computed to be in the range of $81 \%$ to $97 \%$, with the major1 ty over $90 \%$. The calculated volumes are recorded on the summary sheets.

Earlier siudies 1l: the laboratory and field have shown that gas generation 1 n the waste drums depends on (1) the quantity of radionuclide, (2) the size and distribution of the radionuclide particles, and (3) the Identity of the hydragenous substrate. The effective contact of the contaminant with ihe waste is very Important in determining the rate of gas formation. As the waste ages and begins to decompose, the radioactive particles are in less efficient contact with the substrate and therefore less gas is generated. It was shown in the Laboratory's cylinders that agitation of the container can temporarily reverse this process, but the reversal is short-11ved, and the rate of gas formation continues to decrease with time. 2 The tabulated 
results of the gas analyses from the $238 \mathrm{pu}$ waste drums $111 \mathrm{us}$ trate this polrt. The drums that contain a potentially explosive gas mixture are all in the group of "new" (8-month-old) drums. The 3- and 9-year-old drums contain amounts of $\mathrm{CO}_{2}$ that suggest that there has been significant radiolytic gas generation earlier, but the very $10 \mathrm{w}_{2}$ mole percentages indicate that current $\mathrm{H}_{2}$ production $1 \mathrm{~s}$ minlmal, and that $\mathrm{H}_{2}$ produced earlie. has long since diffused from the containers.

\section{REAL-TIME FADIOGRAPHY}

Most of the drums selected for this program were exannined by real-time radiography ( $R i n$ ) and recorded on a video tape. The primary purpose for this effort was to verify, to the extent possible, that the contents of che drums did not pose any signiflcant hazard in subsequent handling and sampling operations. It also was of 1 nterest to see, however, if adequate Information could be determined through this observation to certify the waste contents.

The equipment : tilized was that avallable at Los Alamos. It was state-of-the-art circa 1974 and was not procured especially for the purpose of TRU waste certification. A radiography equipment setup 1dentical to the one used for this work is shown in Figure 17. It consists of a $2-\mathrm{MeV} x$-ray source, the 55-gallon drum to be radiographed, and a 36-by-36-1nch fluorescent screen in front of a bellows. Behind the bellows is a silicon-electron-tibe image intensifier that feeds the signal into a digital video processor. The linage will appear on a cathode-ray tube where 1 t can be viewed and/or photographed, or the signal can be fed to a video recorder where a tape of the drum can be recorded as the drum is moved around in a circular motion as we 11 as up and down to obtain the best possible identification of the contents. For containers involving difficult or extremely dense contents, x-ray fllm can be exposed directly 


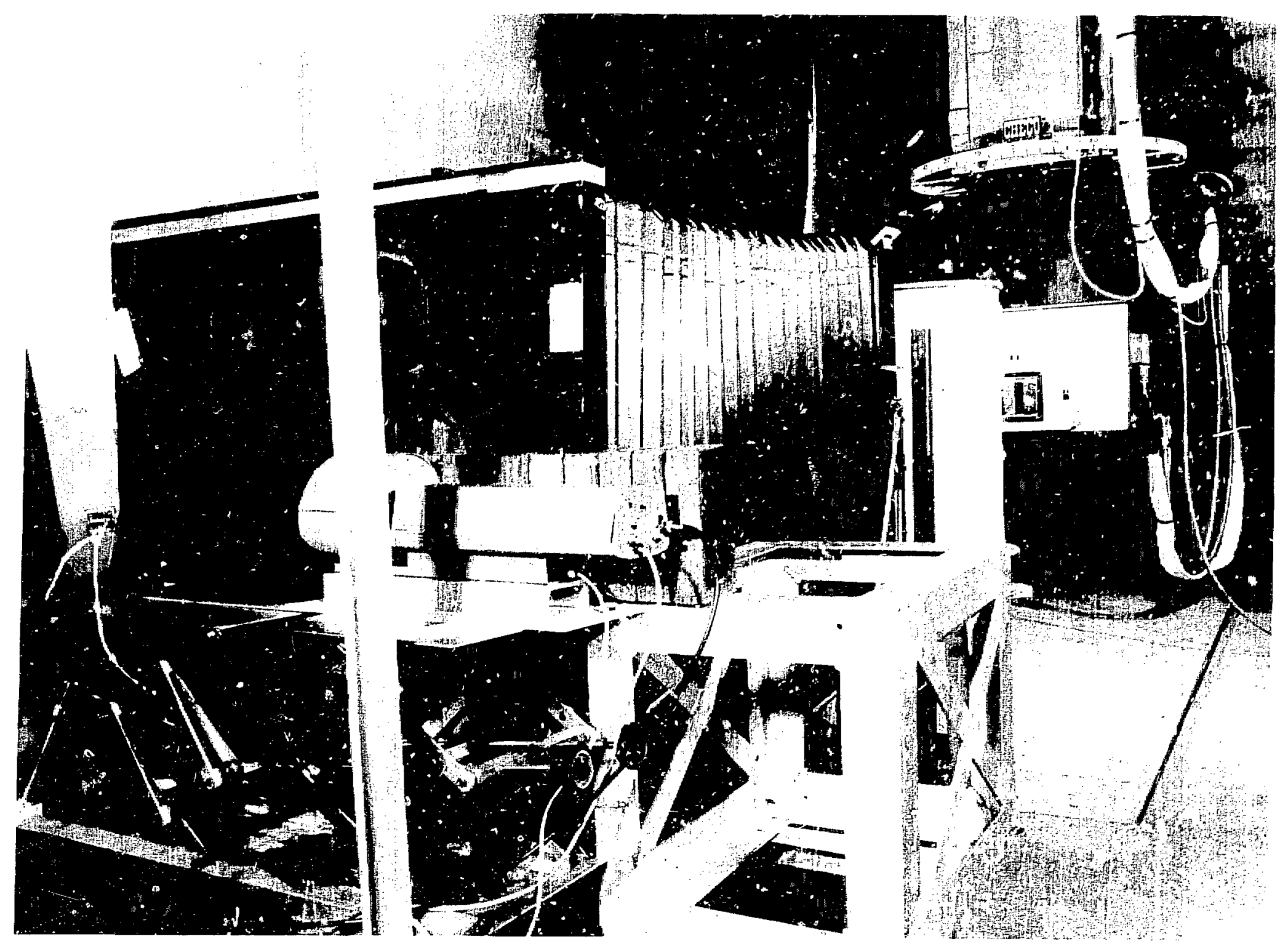

Fig. 1.7. Rea1-Time Radiography setup. 
behind the drum, allowing long exposures that will penetrate the substrate to improve resolution and definition. Current state-of-the-art equipment designed specifically for examination and certification of waste contalners would have much better resolution and provide a more satisfactory examination of the contents of the drums. A few of the drums could not be radiographed in the equipment avallable because of their excessive weight. The RTR was performed by John M. Bieri of the Los Alamos Advanced Nuclear Technology Group Q-2.

Two persons (not radiologists) independently reviewed the video tapes that were recorded on the equipment described abovo. Their descriptions are recorded on the summary sheets (Appendix 2). At the time the tapes were reviewed, the drums had not been opened, and no descriptions of the contents were avallable to the viewers. It was felt that this examination would probably be satisfactory for certification in most but not all cases. As noted in the attached summary sheets, three drums subsequently were found to contaln small quantities of free 11quids, one drum contained a quantity of particulate, and one drum had corrosive material that was not adequately contained. None of these were detected by the RTR.

\section{WALL THICKNESS OF DRUMS}

The wall thickness of drums was measured with a NoVA Mode1 01 Ultrasonic Th1ckness Gauge. Following calibrations with coupons of known thickness, we took measurements in at least three wide-ranging locations on drum 11ds, side walls, and bottoms. Readings were averaged so that a single value could be reported, but they were found to be remarkably uniform. These results are presented in Table V. 


$$
\begin{aligned}
\text { TABLE } & \text { V } \\
\text { ULTRASONIC THICKNESS GAUGE MEASUREMENTS } & (1 / 1000 \text { inch })
\end{aligned}
$$

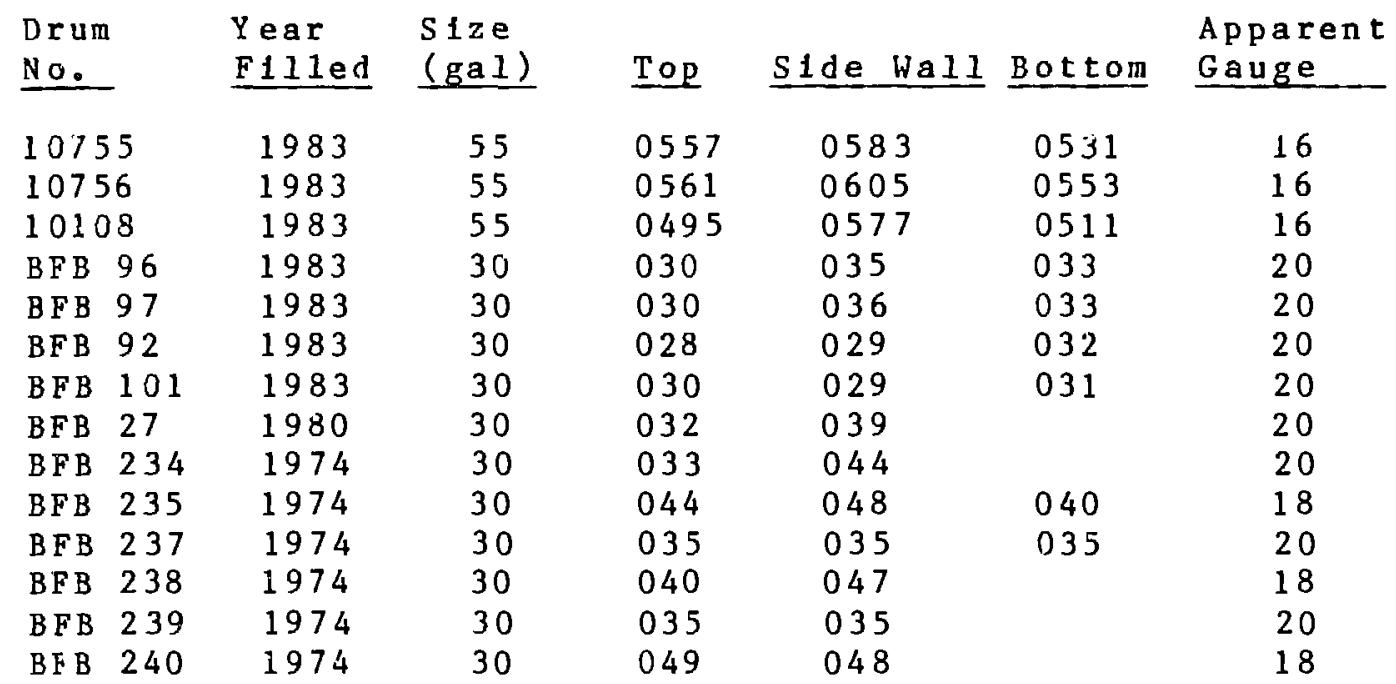


Later visual inspection of the inner surfaces of the drums verified that there had been no significant corrosive dererioration of any drum. The worst case was the lid of drum BFB-240. When the cask where 1 t was stored was opened, we found rust and standing water on the 11d; however, the thickness of the $11 d$ was st1110.049 1nch (w1thin specs for 18 gauge) so the contalner integrity had not been reduced significantly at this time. When this drum was opened, it was found to be rusted inside, but the side-wall thickness was still 0.048 inch. The drum contained a leverpak that was severely water damaged. It was double-bagged with plastic, and there were approximately $150 \mathrm{ml}$ of water in the space between the two plastic bags. The metal cans and other metal objects inside the leverpak were very rusty. The rust was in large bundles of scale, not dust. Because the two plastic bags around the leverpak were still sealed and had not been penetrated, it is not clear whether there was a causative relationship between the conditions inside the leverpak and outside the drum. Table IV shows the results of thickness measurements of several drums chosen at random. More of the 30-gallon drums were measured because they were older and contalned 238 pu-contaminated waste, which was felt to be a potentially more corrosive environment. However, the differences in thickness of these drums appear to be only differences in manufacturing lots rather than the effects of corrosion.

It should be noted, however, that the equipment utilized in these thickness measurements is not capable of detecting small pltting corrosion. As noted, there was no significant corrosion observed on subsequent opening and inspections in most of the drums. AII of the 30-gaIlon drums of $238 \mathrm{pu}$ waste also will require being overpacked before shipment to WIPP, and thus the drum specification is not important to certification of these packages. 


\section{ASSAY OF TRU CONTENT}

The reassays of the waste drums were done by Ron Blankenship of MST-10, the Nuclear Materials Management Group, using either segmented gamma scan or thermal colncidence neutron (TCN) counter, whichever was more approprite according to recorded contents. The summary sheets (Appendix 2) show that the original assay and reassay values are not always in goor agreement. In all cases, the original values for these drums were determined as the sum of separate measurements of the individual item in the drum. These individual iter measurements were by either TCN or segmented gamma assay (SGA) technicues, depending upon the nature of the liem. All of the reassays, on the other hand, were conducted on entire drums of waste. Because the contents of the drums are a mixture of 1 tems best measured by either TCN or SGA, a portion of the contents of each drum, therefore, is not best measured by the technique applied to the drum as a whole. Thus, when 1 tems are individually assayed and then placed 1 to a drum and assayed collectively, the problems of assay geometry and matrix effects of ten can cause significant differences, and the total assay is not equal to the sum of the individual assays. All of the drums reassayed were found still to be within the limits of the WIPP-WAC for TRU content.

\section{DRUM OPENING, WASTE INSPECTION, AND SAMPLING}

When all other measurements had been completed, the drums were delivered to the Los Alamos SRF for examination and verification of the contents. All of the 30-gallon drums (18) containing $238 \mathrm{Pu}$-contaminated waste, and 11 representative 55galion drums containing 239 pu-contaminated waste, were opened. A special glovebox and drum-handiling rack (Figure 18) were constructed and placed inside the large enclosure usually used for TRU waste-size reduction. Each drum was we1ghed (Figure 19) 


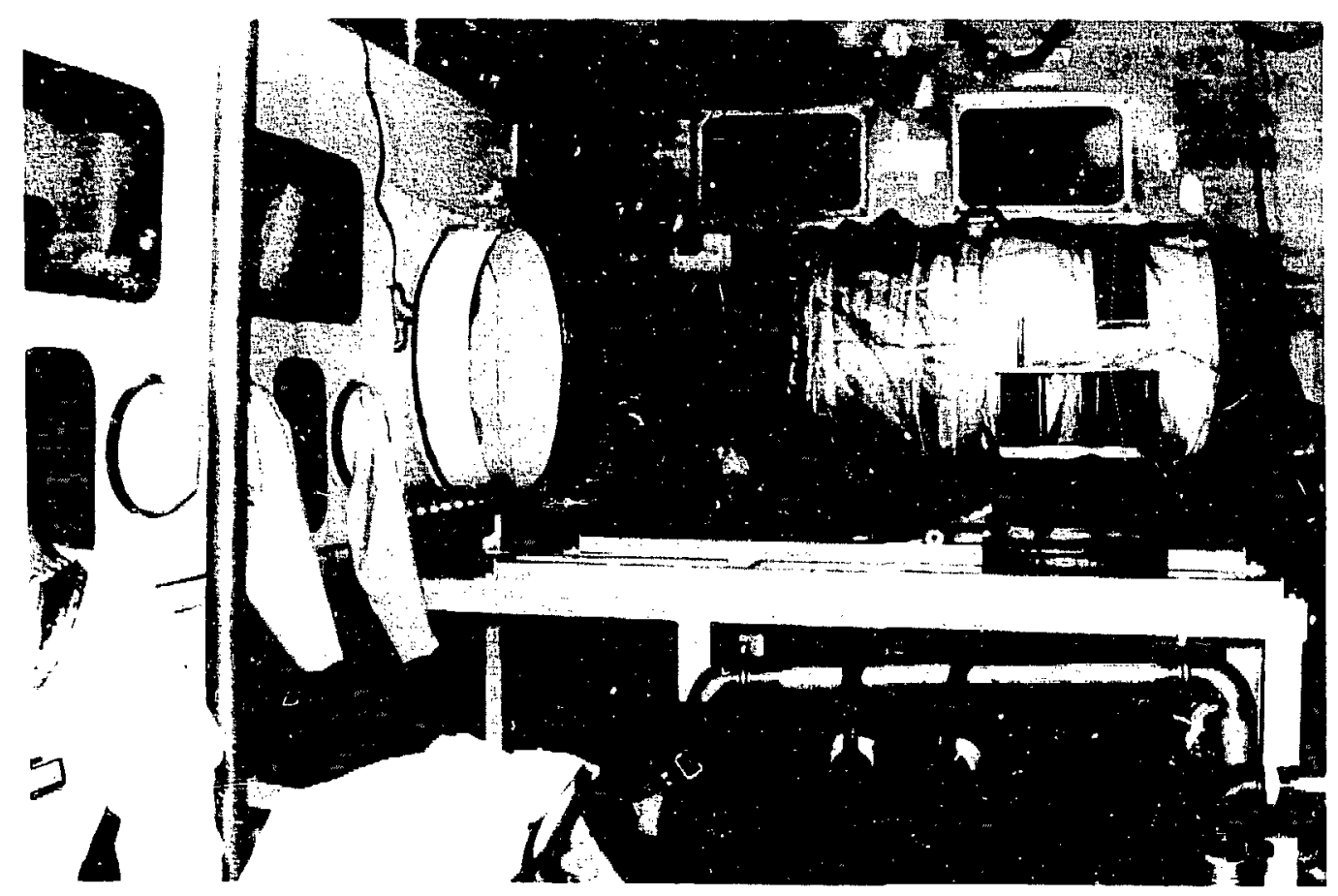

Fig. 18. Waste drum in place on rack in SRF. Preparing to slide drum into drybox and remove lid.

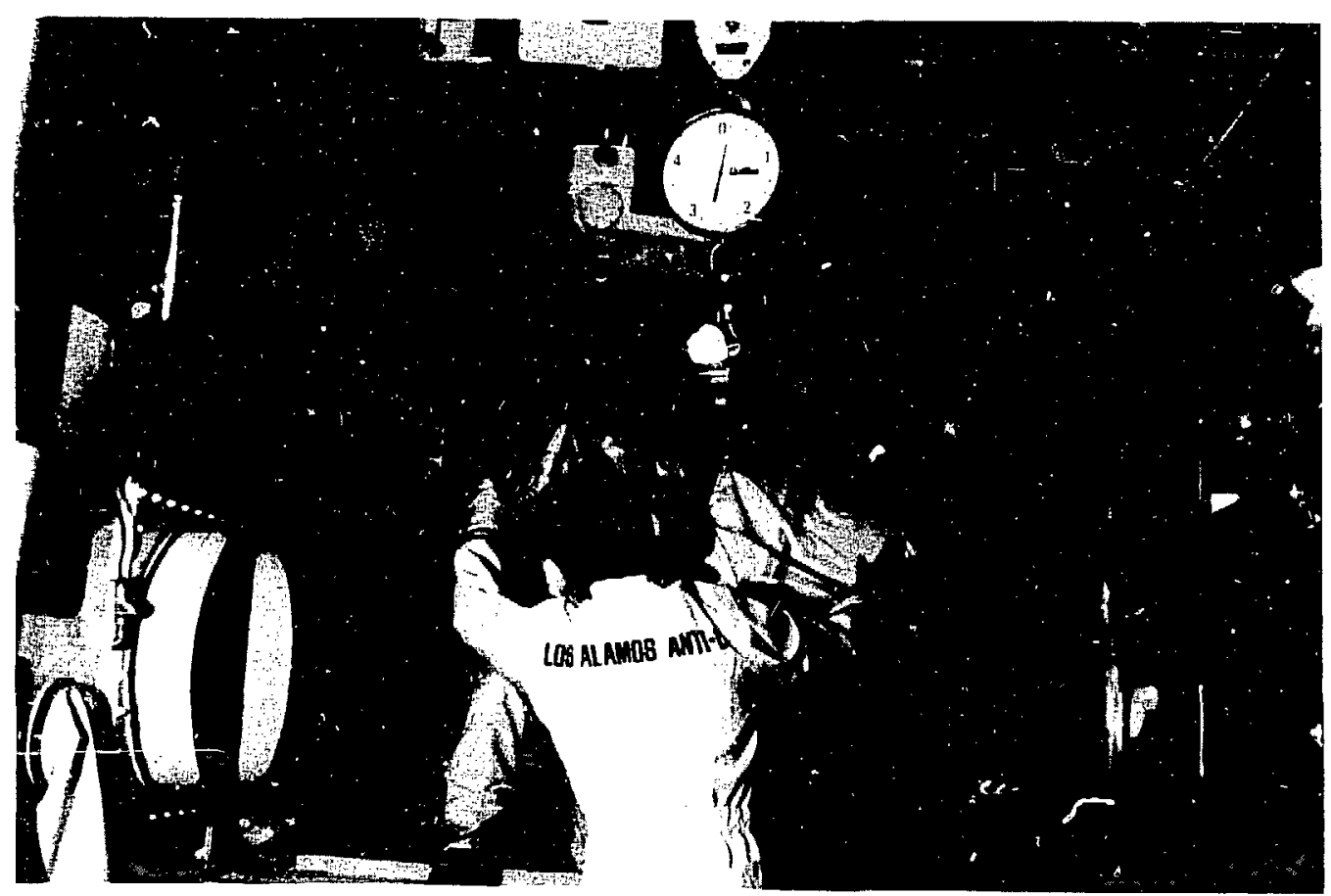

Fig. 19. Each drum examined in the SRF was weighed. 
and had the top and upper part of the exterior side walls taped with plastic to expedite later decontamination. Each drum in turn was then clamped horizontally on the rack, and the top of the drum pushed through a circular port (F1gure 20) into the speclal glovebox. The annular space between the drum and the port was sealed with plastlc. The locklng ring, 11d, and contents of the drum were then removed and examined (Figures 21 and 22). The varlous fractions of waste were separated and welghed (Appendix 3). The materials were categorized to see if they matched the description given on the original disposal record, and if they we re in compliance with WIPQ-WAC (Appendix 4). Samples were taken of materials if 1 t appeared that more work might be indicated to categorize or identify them. Particulate was collected and measured where there was kufficient material avallable. Sleves used to categorize particle size were 212 and 75 micrometers. Johnny Harper and Bruce Reich of the Waste Management Group HSE-7 were Instrumental in directing the accomplishment of this portion of the work.

\section{SLUDGE CORE ANALYSES}

Four 55-gallon drums contalning vacuum-filtered chemical treatment sludge were chosen for a speclal study. These drums were opened in the SRF and core samples withdrawn. Visual inspection indicated no free liquid, droplets, or other forms of molsture. Meaningful core samples for molsture content were not obtalned, however, due to nonavallability of sultable equipment. By the time the difficulties were discovered, $1 t$ was too late to correct the problem. The core samples for each drum were carefully mixed, and a representative sample taken to by analyzed for $238 \mathrm{Pu}, 239 \mathrm{Pu}$, and $241 \mathrm{Am}$ content. The results of the analyses reported in TableVI show that the levels of contamination in sludge are so low that no gas generation problem would be expected to exist. These values are in reasonable agreement except for the ${ }^{239} \mathrm{pu}$ analyses. The counts for these 


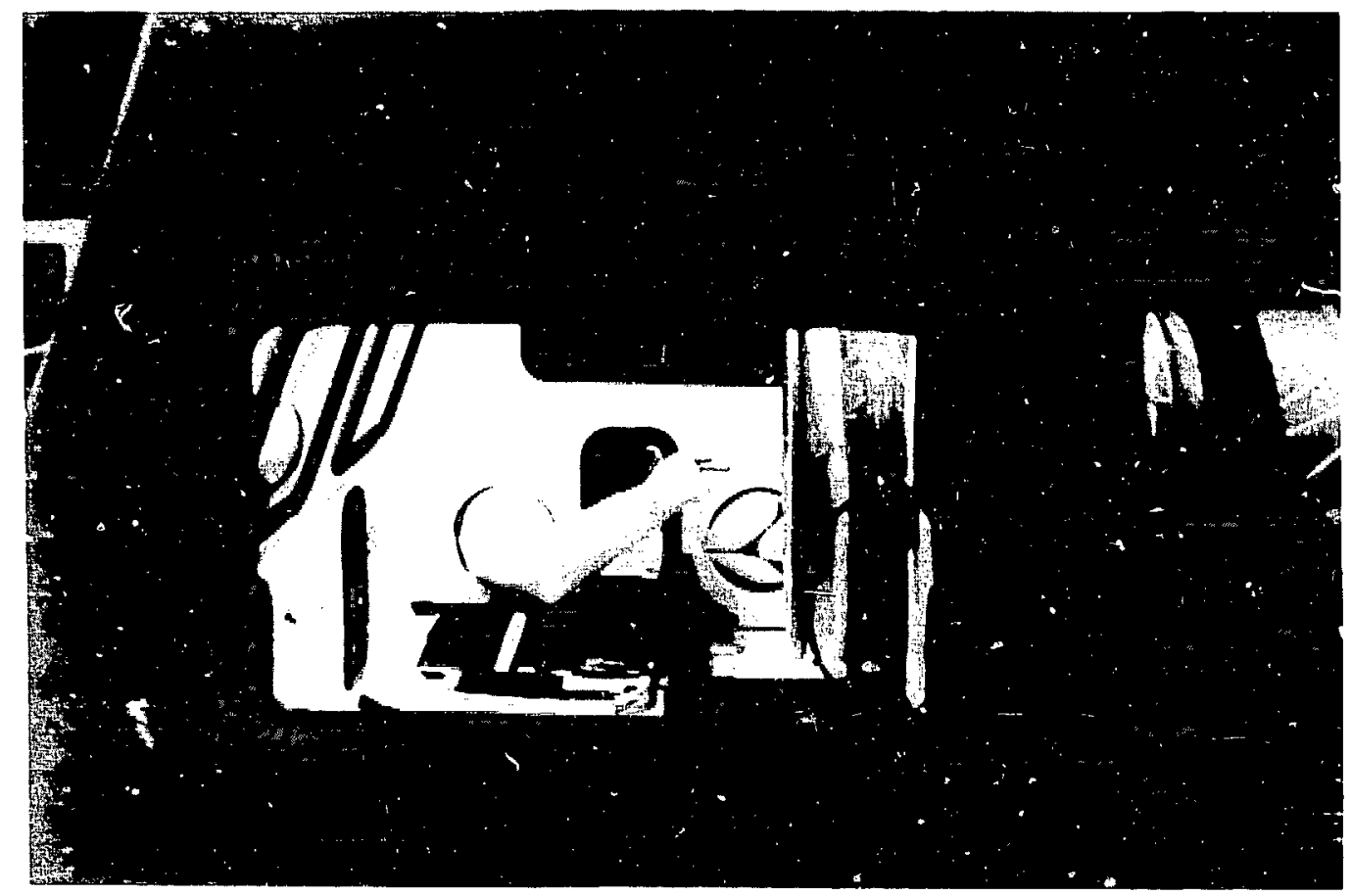

Fig. 20. Removing the drum locking ring and 1id.

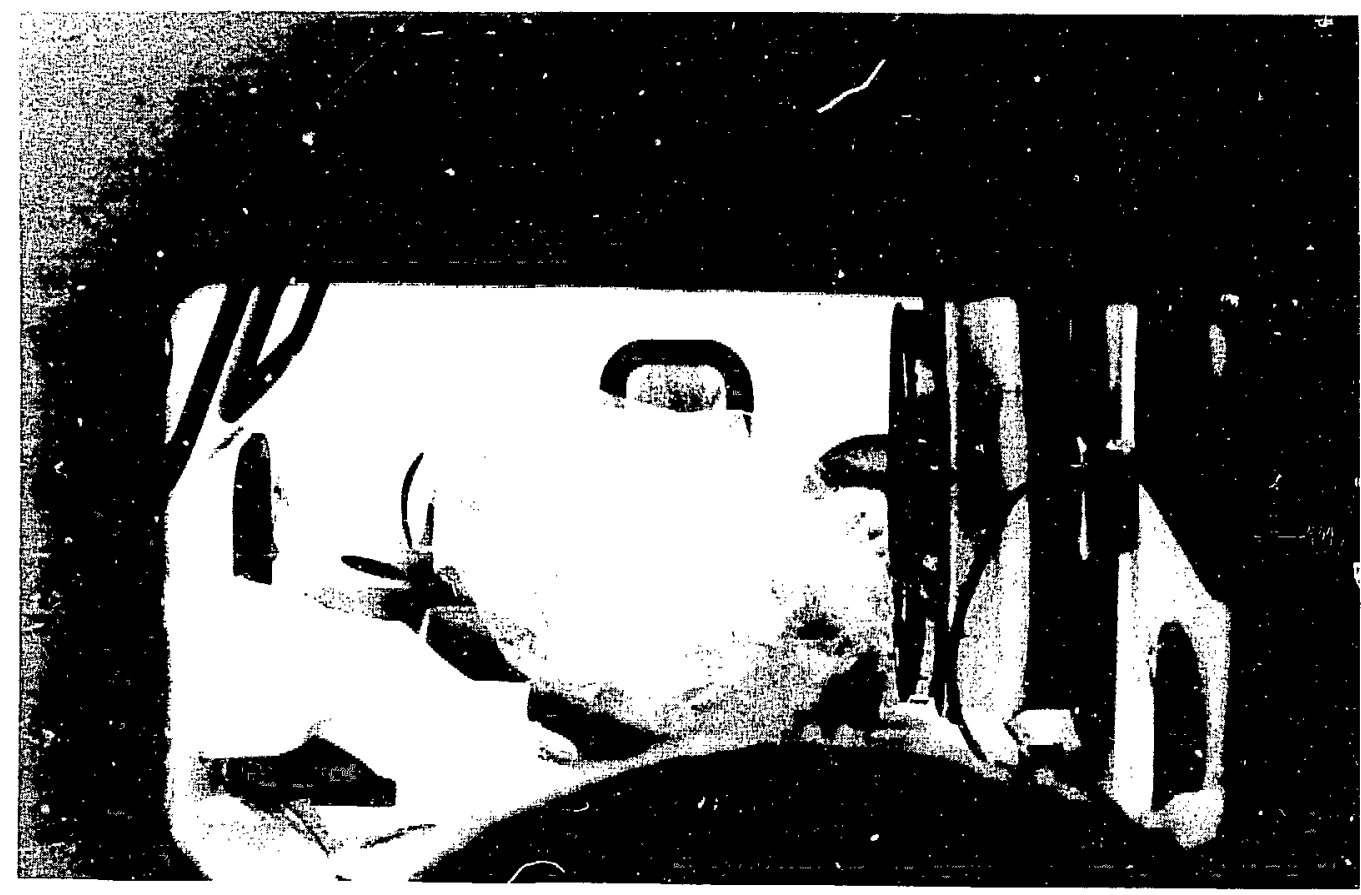

Fig. 21. Examining the waste contents of a drum. 


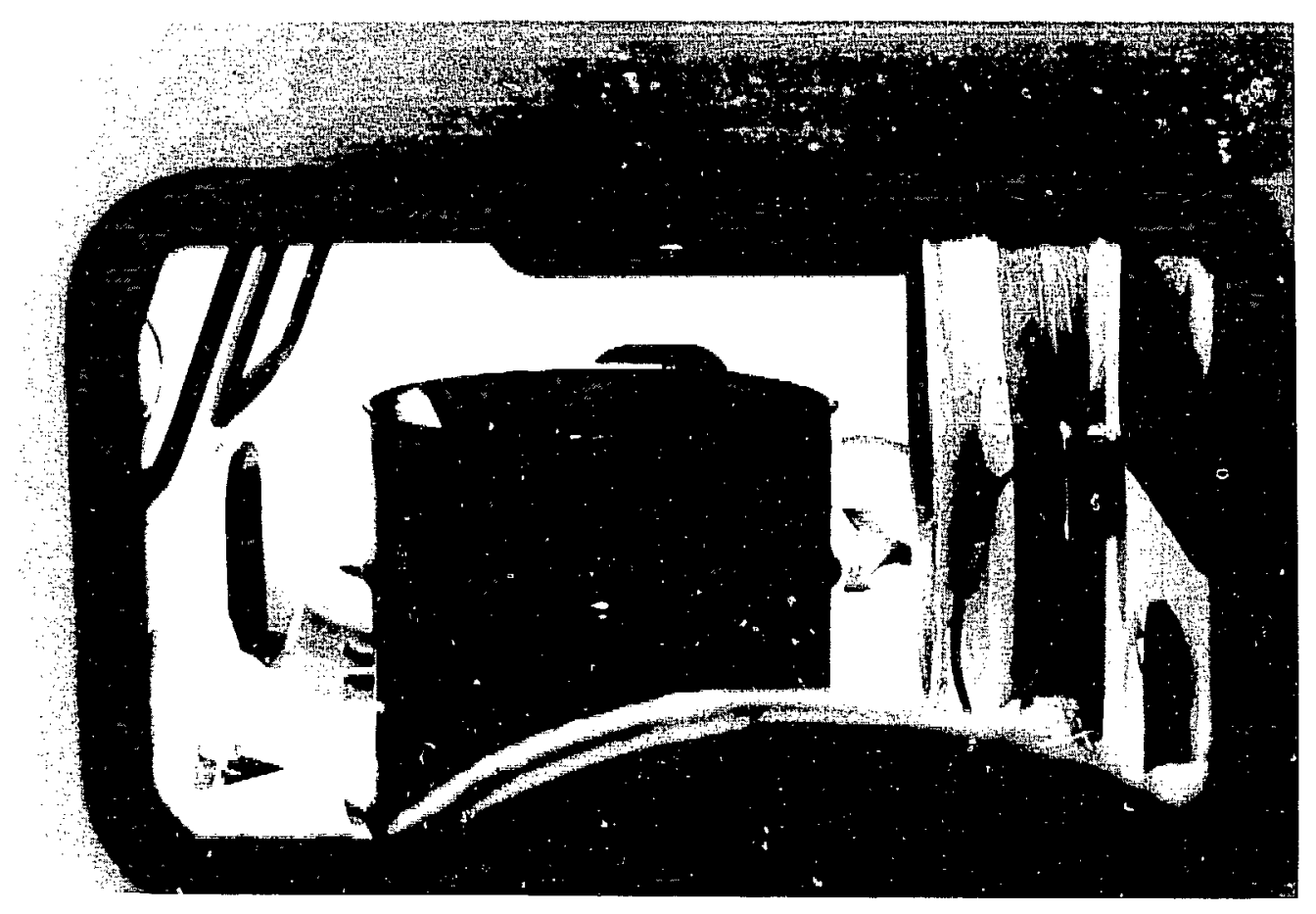

Fig. 22. This 55-gallon a um had a 30-gallon drum inside. 
analyses were checked and no errors were found in the computations, but they appear to be low by a factor of 10 . Comparisons with a number of sludge samples analyzed before and since these four indicate that the $239 \mathrm{Pu}$ radioassay should be In the $10^{-1}$ range, as the original batch samples were. The agreement of the values for $238 \mathrm{Pu}$ and $24{ }^{1} \mathrm{Am}$ glve credence to the practice of radioassaying thoroughly mixed batches rather than Individual drums.

TABLE VI

ANALYSES OF VACUUM-FILTERED CHEMICAL TREATMENT SLUDGE

(Values in curles per drum)

DRUM/I sotope

012124

$\begin{array}{ll}238 \mathrm{Pu} & 1.67( \pm .1) \times 10^{-2} \\ 239 \mathrm{Pu} & 1.74( \pm .1) \times 10^{-1} \\ 241 \mathrm{Am} & 3.56( \pm .25) \times 10^{-1}\end{array}$

012307

$238 \mathrm{pu}$

$239 \mathrm{Pu}$

$241_{\mathrm{Am}}$

012327

238 P u

$239 \mathrm{Pu}$

241 A m

012535

$238_{\mathrm{Pu}}$

$239 \mathrm{Pu}$

$241_{\text {A m }}$
OrIginal Batch

$1.74(\mp .1) \times 10^{-1}$
$3.56( \pm .25) \times 10^{-1}$

$1.67( \pm .1) \times 10^{-2}$

$1.74( \pm .1) \times 10^{-1}$

$3.56( \pm .35) \times 10^{-1}$

$1.67( \pm .1) \times 10^{-2}$

$1.74( \pm .1) \times 10^{-1}$

$3.56( \pm .25) \times 10^{-1}$

$$
\begin{aligned}
& 1.67( \pm .1) \times 10^{-2} \\
& 1.74( \pm .1) \times 10^{-1} \\
& 3.56( \pm .25) \times 10^{-1}
\end{aligned}
$$

$1.67( \pm .1) \times 10^{-2}$
Core Sample

$1.55( \pm .20) \times 10^{-2}$

$1.48(\mp .19) \times 10^{-2}$

$2.32( \pm .09) \times 10^{-1}$

$2.71( \pm .46) \times 10^{-2}$

$1.57( \pm .19) \times 10^{-2}$

$2.37( \pm .07) \times 10^{-1}$

$1.53( \pm .20) \times 10^{-2}$

$1.72( \pm .22) \times 10^{-2}$

$2.42( \pm .24) \times 10^{-1}$

$6.05( \pm .79) \times 10^{-3}$

$2.18( \pm .24) \times 10^{-2}$

$2.90( \pm .23) \times 10^{-1}$ 
As a further study, three drums of cemented sludge were sampled for gas content after they had been sealed from 20 to 70 days; they were found to be at atmospherlc pressure. Analyses of gas samples withdrawn from each verified the conclusion drawn earlier from the cored sludge: no signiflcant gas volumes are being generated. Table VII shows these gas values.

TABLE VII

ANALYSES OF GAS FROM DRUMS OF CHEMICAL TREATMENT SLUDGE

\begin{tabular}{|c|c|c|c|c|c|c|c|c|c|}
\hline \multirow[t]{2}{*}{ D rum } & \multirow[t]{2}{*}{$\begin{array}{c}\text { Age } \\
\text { (days) } \\
\end{array}$} & \multicolumn{8}{|c|}{ Gas Analysis (mol $1 \%)$} \\
\hline & & $\underline{\mathrm{H}}_{2}$ & $\underline{\mathrm{O}}_{2}$ & $\underline{\mathrm{CO}}_{2}$ & $\underline{\mathrm{CO}}$ & $\underline{\mathrm{CH}}_{4}$ & $\underline{N}_{2}$ & Ar & $\underline{\mathrm{He}}$ \\
\hline $\begin{array}{l}50011 \\
50016 \\
50048\end{array}$ & $\begin{array}{l}20 \\
20 \\
70\end{array}$ & $\begin{array}{r}<0.1 \\
0.1 \\
0.1\end{array}$ & $\begin{array}{l}19.1 \\
18.1 \\
20.2\end{array}$ & $\begin{array}{l}0.1 \\
0.2 \\
0.2\end{array}$ & $\begin{array}{l}<0.1 \\
<0.1 \\
<0.1\end{array}$ & $\begin{array}{l}0.1 \\
0.2 \\
0.2\end{array}$ & $\begin{array}{l}79.8 \\
80.4 \\
78.3\end{array}$ & $\begin{array}{l}0.9 \\
1.0 \\
0.9\end{array}$ & $\begin{array}{l}<0.1 \\
<0.1 \\
<0.1\end{array}$ \\
\hline
\end{tabular}




\section{DISCUSSION OF STUDIES}

Perusal of the visual examination data collected on the sumary sheets indlcates that 5 of the 33 drums opened and examined ( $14 \%$ ) definite1y could not be certifled is packaged. Three contalned free 11 quids, one contalned corrosive materials, and one had too much unstabilized particulate. The one with particulate, a process residue waste, was not expected to be certifiable. Drum BFB-234, one of the $30-g a 11 \mathrm{cn}$ drums of $238 \mathrm{Pu}$ waste, contalned a bag wih several small cans. Wet materlal (not free 11qu1d) had corroded through the wall of one of the cans and had started to corrode two other cans from the outside. A sample of this material showed 1 to be acidic $238 \mathrm{pu}$ oxide, with a pH of 3. Conta1ner 010435, a 55-galion drum of 239 pu-contaminated waste, was another drum that appeared to be certifiable when examined by RTR. Visual examination revealed a container of filtering ald in this drum that was $35.4 \%$ of the total contents' welght. One hundred percent of this particulate materlal was smaller than 75 micrometers. Without stab1lization, this material is not certifiable. The three drums that contalned free liquids were as follows:

- Drum 010761, a 55-ga11on drum of $239 \mathrm{Pu-contam1-}$ nated, combustible, room-decontamination waste that contained a plastic hand-lotion bottle still holding approximately $60 \mathrm{ml}$ of hand lotion.

o Drum 010925, a 55-gallon drum of 239pu-contaminated, leached process residues packaged in multiple cans, each of which contalned 100 to $150 \mathrm{ml}$ of free $11 q u 1 d$, for an aggregate of 211 ters to 3 11 ters. Clearly this material is not certifiable until the liquids have been solidified. 
- Drum BFB-240, a 30-ga11on drum of 238 pu-contam1nated waste. Inside was a double-bagged leverpak, and between the two bags was approximately $150 \mathrm{~m} 1$ of water. Because the leverpak was saturated, it seems probable that the water came from the inside; however, this is the drum that was found to have standing water on the lid when the concrete storage cask was opened. Figure 23 is a print of the radiograph of this drum, showing that the water cannot be seen.

Eleven drums had the wrong (or at least not the most approprta te) Los Alanos waste code assigned. All of these contained significant portions of combustible material, so this inappropriate coding would not have been a problem for certification.

The packaging efficlencles seeme poorer than destrable: $93 \%$ of the drums were $50 \%$ to $95 \%$ f 111 ed, while only $66 \%$ were $75 \%$ to $95 \%$ filled. One drum ( $3 \%)$ was only $25 \%$ full, and another $35 \%$. There is probably some settling of the contents of the waste material with time, but it does appear that a more efficient use of the disposal volume could be made with a reasonable effort on the part of the waste generators. The calculated vold volumes were around $90 \%$; this percentage was expected, especlally for organic waste. No pyrophorlc materials, explosives, toxic matertals, or compressed gases were found in any of the drums examined. Except for drum BFB-234, corrosive materials If present were properly packaged to meet WIPP-WAC criceria. Detalls of these categories may be found in Appendix 4.

Descriptions of several of the 238 Pu waste drums mention a red or brown dust that was observed (e.g., BFB-19, BFB-238). Usually the observers made the statement that "there was not enough to collect." Some of this materlal probably was rust. However, a portion of it may have been a degradation product 


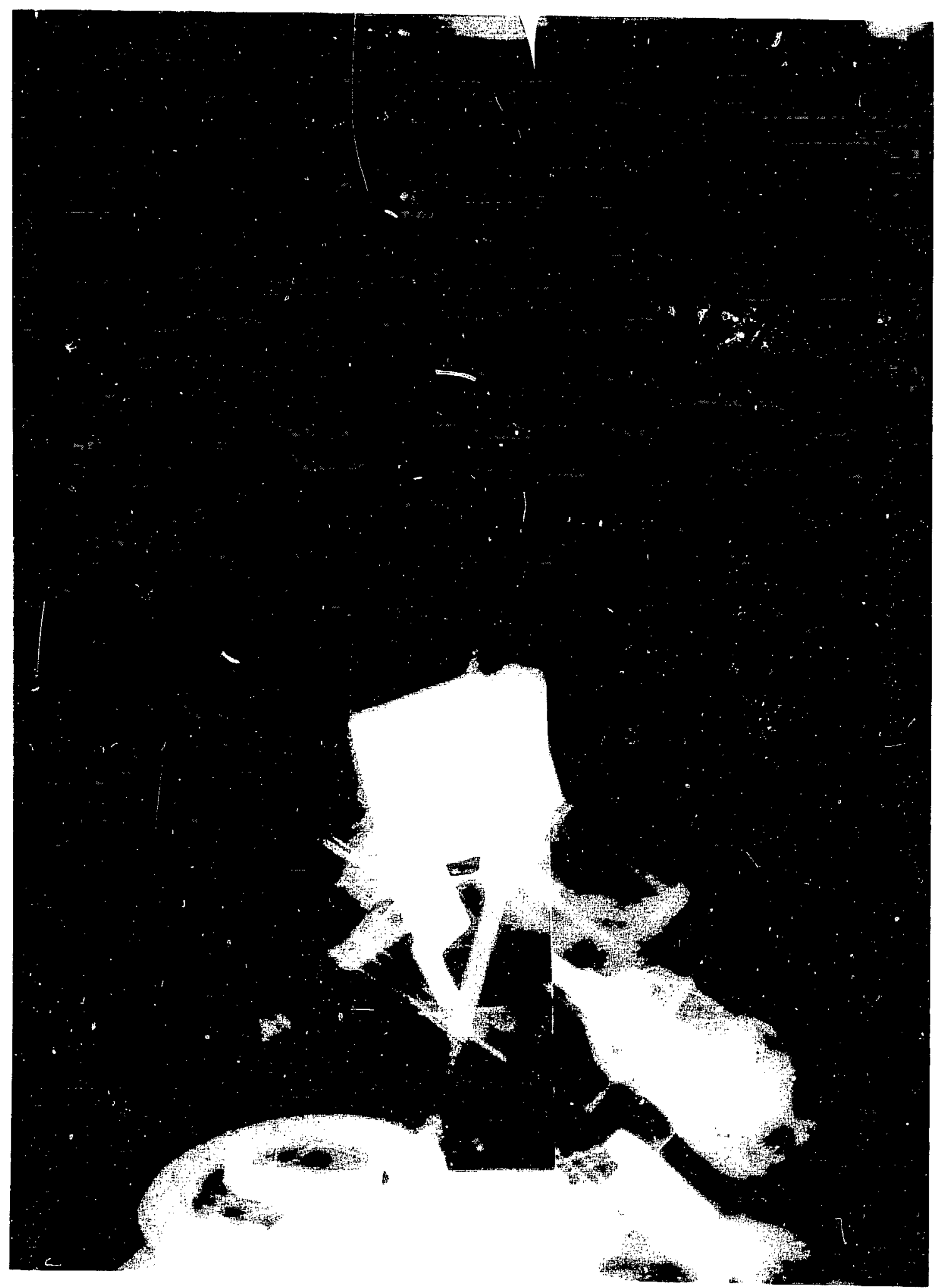

Fig. 23. Radiograph of drum BFB-240. RTR does not show water. 
from the alpha-attack of 238 pu on cellulosics. This product has been previously observed in laboratory experiments (Ref. 2 , pp. 10, 11, 14, and Figure 19). These particles are low density, extremely fine, eastly rendered alrborne, and generally highly contaminated. Clearly this material could be a potential for spreading contamination if contalners of contaminated waste have to be opened. ith ds degradation product is rarely observed In drums of 239 pu-contaminated waste. Drum 010753 is the only instance of the brown powder 1 n $239 \mathrm{pu}$ waste seen to this time; it is definitely an exception. In all of these $1 n^{-}$ stances, however, the quantity of particulate was not sufficlent to render the drum noncertffiable. Obviously the particulate is not present when the drums are originally fllled, but its potentlal presence in older drums must not be forgotten.

The waste-process solids, waste codes A-25 through A-29, are always in a doubtful category for certification because of the posstbilities of free liquids, too many fines in the particulates, or corrosive attack on the contalners. Some might be certiflable, but most probably will have to be processed. Among the $239 \mathrm{pu}$ drums examlned, the following are examples:

- Drum 010108. There 1 s no practical way to know whether the damp particulate wastee meet particle-size criteria. Clearly it would be desirable and less expensive to solidify. the materials before they are packaged.

- Drum 010925. Th1s drum was not certifiable because of the free liquld, but even if 1 t had been dry, the problem of particle size would still make it suspect. 
SUMMARY

0

Most waste was found to be certiflable; five drums were not, and one of these was not expezted to be. Two of these were not certiflable because of free liquid, one because of Improperly contained corrosive, and one (suspected In advance) because of free liquid and potential particulate.

0

Most drums were in good condition when recovered from storage; all were structurally sound and contaminationfree on all exterior surfaces.

0

Radiography was not able to identify unacceptable wastes. However, the system avallable was not designed specifically to perform this task.

$\circ$

There was some deterioration of cellulosic and plast waste 1 n $238 \mathrm{Pu}$ drums as a result of radiolysis. However, all drums were still certiflable, even the 9-yearold waste.

- No drums had gas pressure in excess of atmospheric pressure; all had vented radiolytically generated gases through the porous gasket.

- Three and 9-year-old 238pu waste drums all showed negl1gible mole percentages of $\mathrm{H}_{2}$, although they did contain significant quantities of other radiolytically generated gases, especially $\mathrm{CO}_{2} \cdot \mathrm{H}_{2}$ generation had almost stopped; any significant quantii; of this gas had long since diffused out of the container. However, the 8month-ad drums still contalned significant levels of $\mathrm{H}_{2} \cdot$

- No ${ }^{239} \mathrm{Pu}$ drums contained any potential gas hazard. 


\section{A CK NOWL EDGMENTS}

The authors appreciate the cooperation of Los Alamos National Laboratory personnel in the following groups: Analytical Chemistry ( $\left.\mathrm{CHM}_{-1}\right)$, Advanced Nuclear Technology $(\mathrm{Q}-2)$, Was te Management (HSE-7), Industrial Hygiene (HSE-5), and Health Physics (HSE-1). Without their supporting efforts this work could not have been performed.

\section{REFERENCES}

1. Los Alamos Scientific Labsratory, "Drum Sampling Device," Drawlings Nos. 26Y199057-1, -2,-3 (1975).

2. Al Zerwekh, "Gas Generation from Radiolytic Attack of TRU-Contaminated Hydrogenous Waste," Los Alamors Scientific Laboratory report LA-7674-MS (June 1979). 
APPENDIX 1

LOS ALAMOS WASTE FORM CODES 


\section{Graphite}

Mixed Cel1ulos $1 \mathrm{cs}$

Plastic Materials

Rubber Materlals

Hydracarbon 0118

Silicon Base O11s

Leached Process Residues

Evaporator Bottoms (Salts)

Nitrate Salts

Chloride Salts

Hydroxide Cake

\section{PN Equipment}

Non-PN Equipment

Combustible Hot-Cell Waste

Skull and oxide
Combustible Room Decon. Waste

Mixed Paper, Plast $1 \mathrm{c}, \mathrm{Rubber}$, etc.

MIxed Combustible/Noncombustible Trash

PN Size Reduced Equipment (SPF Only)

Non-PN S1ze Reduced Equipment (SRF Only)

Combustible Bu1lding Debris

Noncombustible Building Debris

Noncombustible Hot-Cell Waste

Uranium Chips and/or Turnings

Slag and Porcelain Crucibles
CODE

$A-50$

$A-51$

$A-52$

$A-55$

$A=56$

$A-60$

$A-61$

$A-65$

$A-70$

$A-71$

$A-72$

$A-73$

$A-74$

$A-75$

$A-76$

$A-77$

$A-80$

$A-85$

$A=90$

$A-95$

$A-99$

\section{WASTE MATERIAL DESCRIPTION}

Metal Crucibles, Scrap, Dies Precious Metals

Other Scrap Metalo

F11 ter Med1a

PIlter Media Residue

other Combustibles

other Noncombustibles

Antmal Tisue

Chem1ca1 Waste

Be

$\mathrm{Hg}$

Counting $V I a l s$ and Solution Ion Exchange Resin

Chemlcal Treatment Sludge Cement Paste

Vermicu $1:$ te

Sources

Firing Point Residues

Contaminated Sol1

G 1 as 8

Unidentifled Material (TA-54 personnel use only) 
APPENDIX 2

WASTE DRUM SUMMARY SHEETS 


\section{Waste Form Category:}

Other Combustibles

$\begin{array}{ll}\text { Container ID: } & \text { BFB-12 } \\ \text { Content Code: } & \mathrm{A}-60 \\ \text { Container Wt. (Kg): } & 18.6 \\ \text { Original Assay (g): } & 6.6 \\ \text { Packaging Location: } & \text { CMB-11, TA-55 } \\ \text { Radionuc1ide: } & 238 \mathrm{Pu}\end{array}$

\section{RADIOGRAPHIC EXAHINATION}

Exam. Da te: $9-93$

Liner Type: None

Lead-Lined?: No

$P$ ackagling

Description: Several plastic bags inside drum.

Can Inside top bag.

Waste Form

Description: Large cylindrlcal contalnor at

angle on top, more denae objects, probably

tools, near bottom.

Absorbent?:

Free Liquids: No.

Compressed

Gasses :

No.

Particulates: No.

Packaging

Efficlency: Approx. $3 / 4$ full.

Volume \%

Combustible:

Correct Con-

tent Code: WI P P

Certiflable?: Yes.

M1sce 11 aneous:

\section{SUMMARY SHEET}

Age When Opened: $\quad 39$ months

Contalner Type: $\quad 30-g a 1 \mathrm{drum}$

Code Description: other Combustibles

Surface Dose Rate: $80 \mathrm{mr}$

Reassay $(g): \quad 4.85$

Date Packaged: $\quad 5-30-80$

Exam. Date:

Contalner

\section{VISUAL EXAMINATION}

Condition:

Lead-L1ned?:

T, 1 ner Type:

\section{$1-84$}

Good. Silght rust film, not

Packaging

Description: Double-plastic-bagged metal can.

There.

can, creating plnholes.

Was te Form

Description: Cheesecloth and filter paper

contents of can were partially burned. Second plastic bag contained rags, cheesecloth, dri11

Absorbent: No. b1ts, wrenches, paper,

Physical State gloves, broken glass. No

of Waste: Dry. deterioration in this bag.

Component Wt. (Kg): 6.5

WIPP-WAC Compliance

Information:

Packaging Efficiency: $15 \%$ vold.

Volume \% Combustible: 50-60\%

Correct Content

$$
\text { Code: }
$$

WIPP Certifiable?

Miscellaneous:

A-19 more approprlate.

red cheeseclith and filter paper were removed

as a sample from one of the bags, but there

appeared no reason to jo an analys $1 \mathrm{~s}$ 
Waste Form Category: Other Combustibles

$\begin{array}{ll}\text { Contalner ID: } & \text { BFB-14 } \\ \text { Content Code: } & A-60 \\ \text { Container Wt. (Kg): } & 27.3 \\ \text { Origlnal Assay (g): } & 1.3 \\ \text { Packaging Locat1on: } & \text { CMB-11, TA-55 } \\ \text { Radionuclide: } & 238 \text { Pu }\end{array}$

\section{SUMHARY SHEET}

$\begin{array}{ll}\text { Age When Opened: } & 36 \text { months } \\ \text { Contalner Type: } & 30-g a l \text { drum } \\ \text { Code Description: } & 0 \text { ther Combustlbles } \\ \text { Surface Dose Rate: } & 2 \text { mr } \\ \text { Reassay (g): } & 0.17 \\ \text { Date Packaged: } & 7-23-80\end{array}$

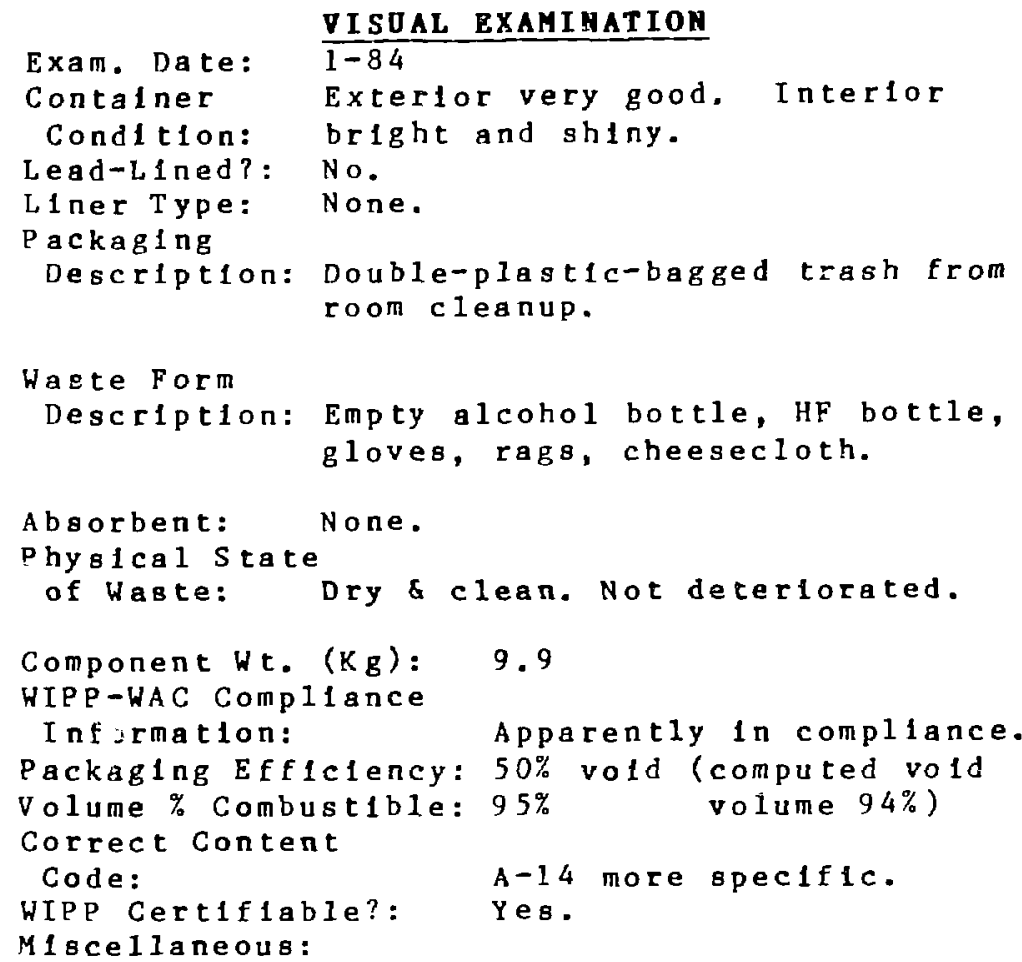




\section{SOHHARY SHEET}

Waste Form Category: other Noncombustibles

$\begin{array}{ll}\text { Container ID: } & \text { BFB-19 } \\ \text { Content Code: } & \text { A-61 } \\ \text { Conta1ner Wt. (Kg): } & 31.8 \\ \text { Original Assay (g): } & 5.6 \\ \text { Packag1ng Locat1on: } & \text { CMB-11, TA-55 } \\ \text { Rad1onuc11de: } & 238 \text { Pu }\end{array}$

\section{RADIOGRAPHIC EXAHINATION}

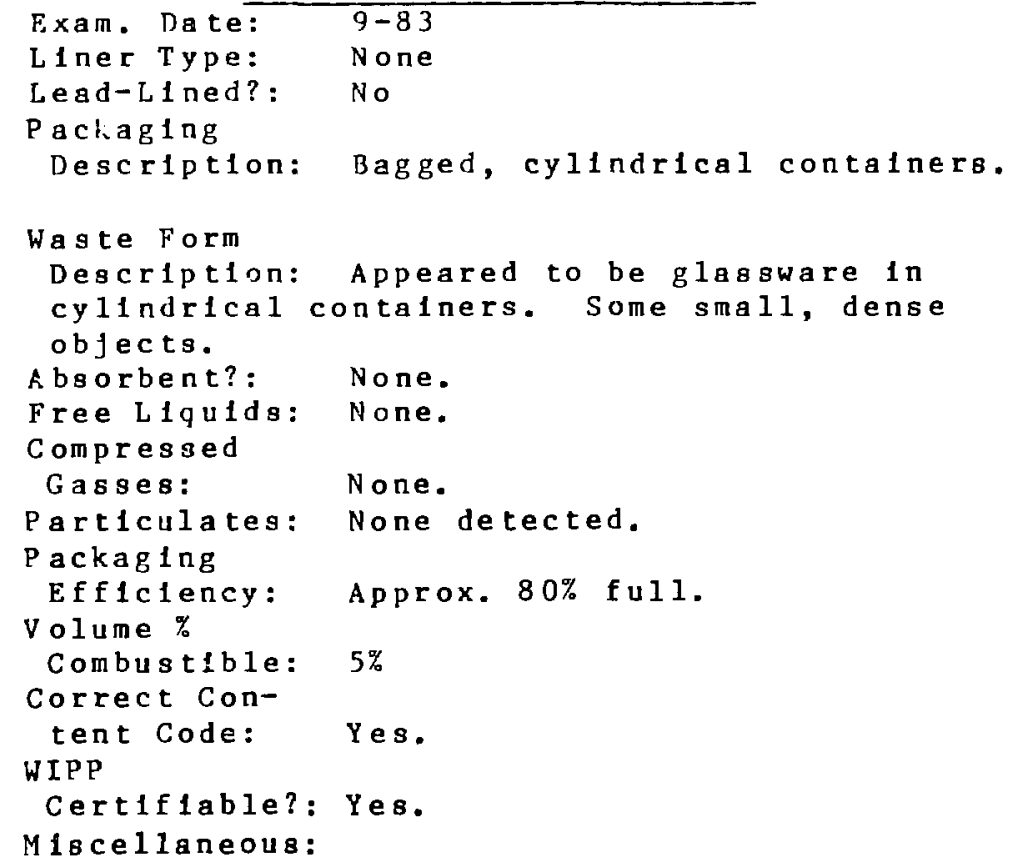

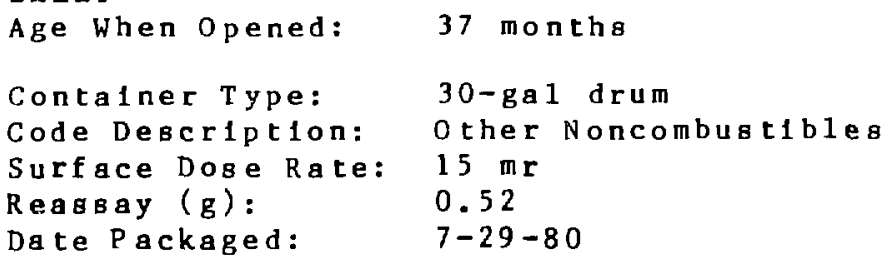

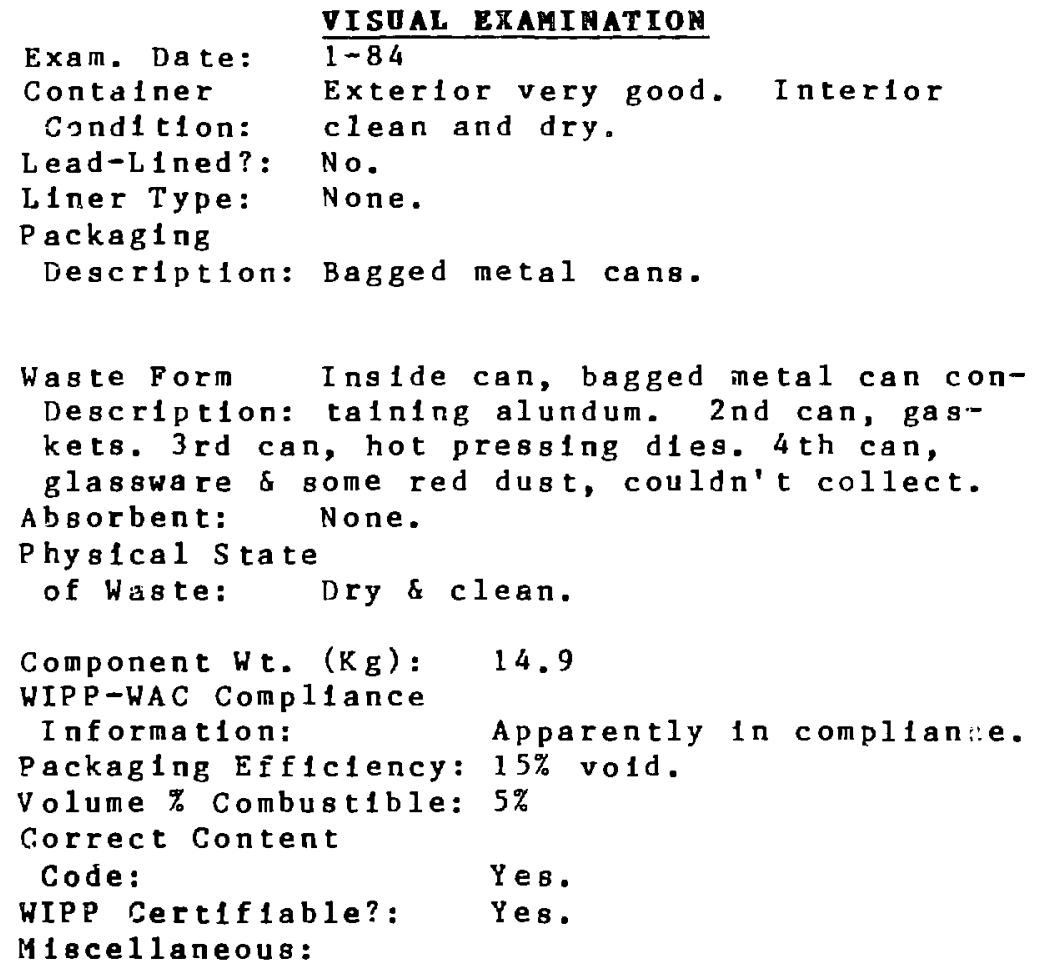




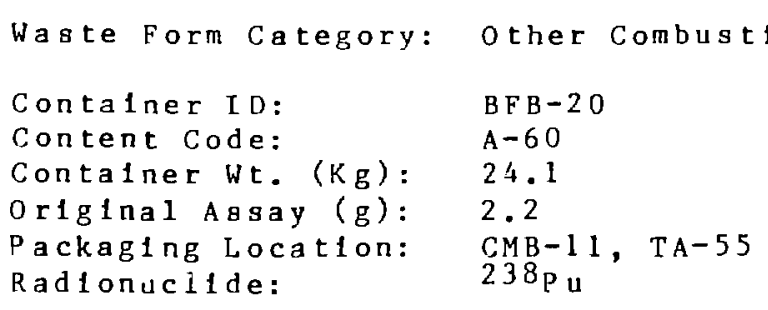

\section{RADIOGRAPHIC EXAHINATIOR}

Exam. Date: $\frac{\text { RADIOGAP }}{9-83}$

L iner Type: None

Lead-Lined?: No

Packaging

Description: Plastic bag, smaller more dense

areas inside. Possibly several smaller bags?

Waste Form

Description: Nothing specifically identifled.

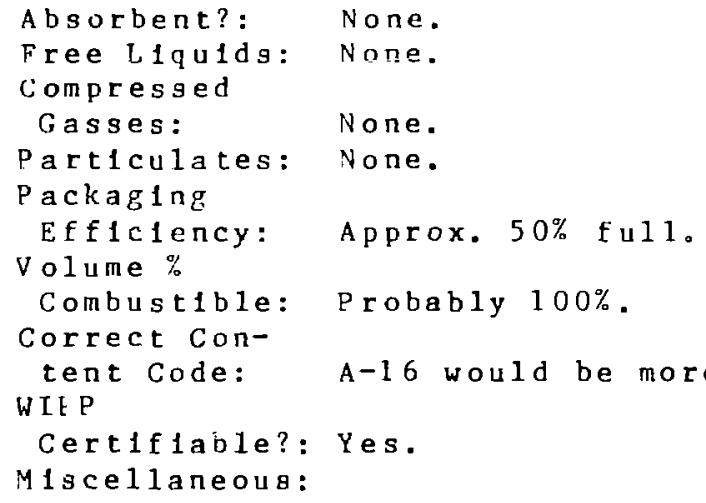

\section{Exam. Date:}

Contalner

Condition:

Lead-Lined?:

Liner Type:

Packag1ng

Description: Plastic bags in 30-gal. drum.

Waste Form

Degcription: Tho bag-olit baga, each filled

with plastic sleeves.

Absorbent: None.

Physical State

of Waste: Dry \& clean.

Component Wt. (Kg): 14.0

WIPP-WAC Compliance

Informat 1 on

Apparently in compliance.

Packaging Efficiency: $50 \%$ vold (computed vold

Volume\% Combugtible: $100 \%$ volume $80.6 \%$ )

Correct Content

Coùe: A-16 is more specific.

WIPP Certiftable?: Yes.

Miscellaneous: 
Waste Form Category: Other Combustibles

Container I D:

Content Code:

Contalner Wt. ( $\mathrm{Kg})$ :

Original Assay ( $g)$ :

Packaging Location:

Radionuclide:

$B F B-26$
$A-60$
25.4
1.05
$C M B-11, T A-55$
238 P

\section{RADIOGRAPHIC EXAHINATION}

Exam. Date: $9-83$

Liner Type: None

Lead-Lined?: No

$P$ ackaging

Description: Bagged trash inside drum.

Waste Form

Description: Forceps, wide-mouth bottle,

2-11ter acid bottle, less dense material near bottom.

Absorbent?: None.

Free Liquids: None.

Compressed

Gasses:

None.

Particulates: None.

Packag $1 \mathrm{ng}$

Efficlency: Approx. $2 / 3$ full.

Volume \%

Combustible: Probably $50 \%$.

Correct Con-

tent Code:

WIPP

Certiflable?: Yes.

M1scellaneous:

\section{SUHMARY SHEET}

Age When Opened: 35 months

Contalner Type:

Code Description:

Surface Dose Rate:

Reassay ( $g$ ):

Date Packaged:

30-gal drum

other Combustibles

$0.2 \mathrm{mr}$

0.0

$9-16-80$

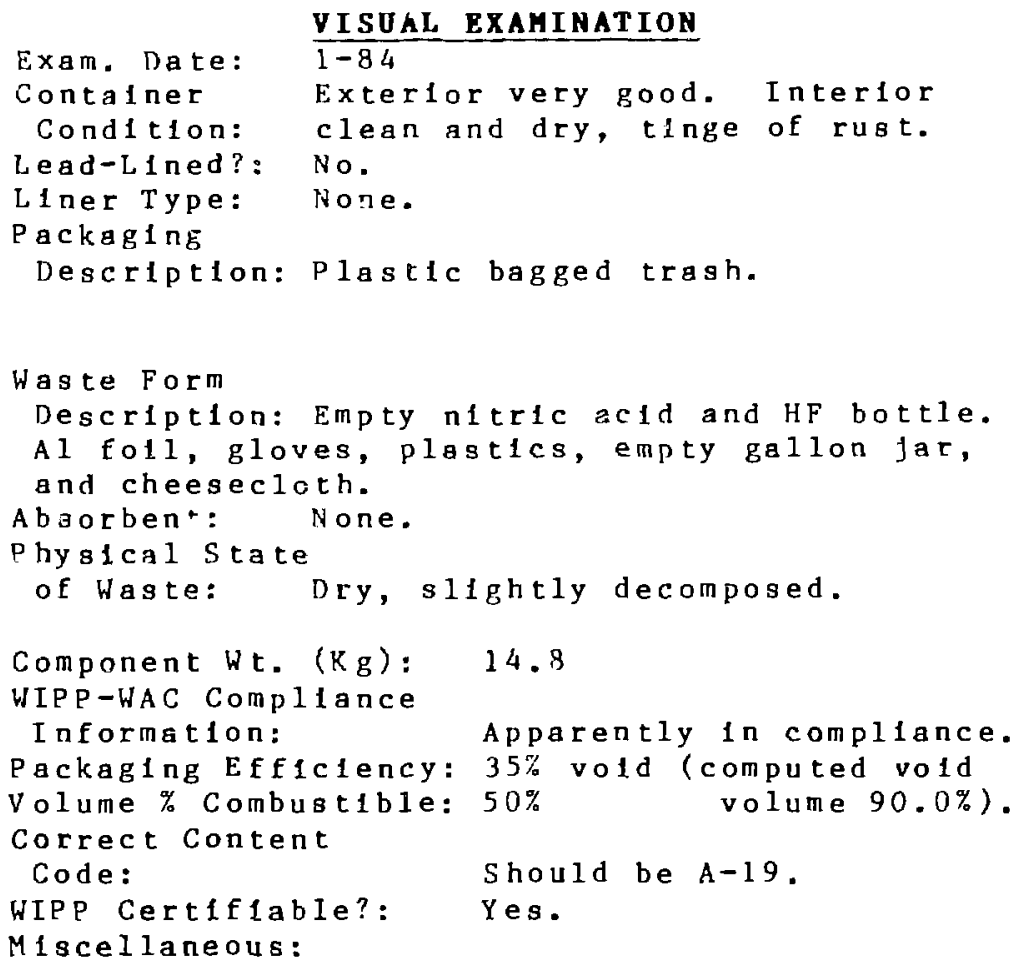

Miscellaneous: 


$\begin{array}{ll}\text { Waste Form Category: } & \text { Other Combust } \\ & \\ \text { Contalner ID: } & \text { BFB-27 } \\ \text { Content Code: } & \text { A-60 } \\ \text { Contalner Wt. (Kg): } & 25.1 \\ \text { Original Assay (g): } & 1.18 \\ \text { Packaging Location: } & \text { CMB-11, TA-55 } \\ \text { Radionuclide: } & 238 \text { Pu }\end{array}$

\section{RADIOGRAPHIG EXAMINATION}

$\begin{array}{ll}\text { Exam. Date: } & 9-83 \\ \text { Liner Type: } & \text { None } \\ \text { Lead-lingd?: } & \text { No } \\ \text { Packaglng } & \\ \text { Description: } & \text { Plastic bag inside drum. }\end{array}$

Waste Form

Description: Appeared to be several plastic

bag inslde one larger bag. Small clrcular

dense spot near bottom, one dense object.

Absorbent?

None.

Free Liquids: None.

Compressed

Gasses:

None.

Particulates: None.

Packaging

Efficlency: Approx. $2 / 3$ full.

Volume \%

Combustible: $100 \%$ of contents.

Correct Con-

tent Code:

WIPP

Certiflable?: Yes.

M1scellaneous:

\section{SUHMART SHEET}

Age When Opened: 35 nonths

Contalner Type: $\quad 30-g a l$ drum

Code Description: Other Combutibles

Surface Dose Rate: Background

Reassay ( $g)$ : $\quad 0.42$

Date Packaged: $\quad 9-12-80$

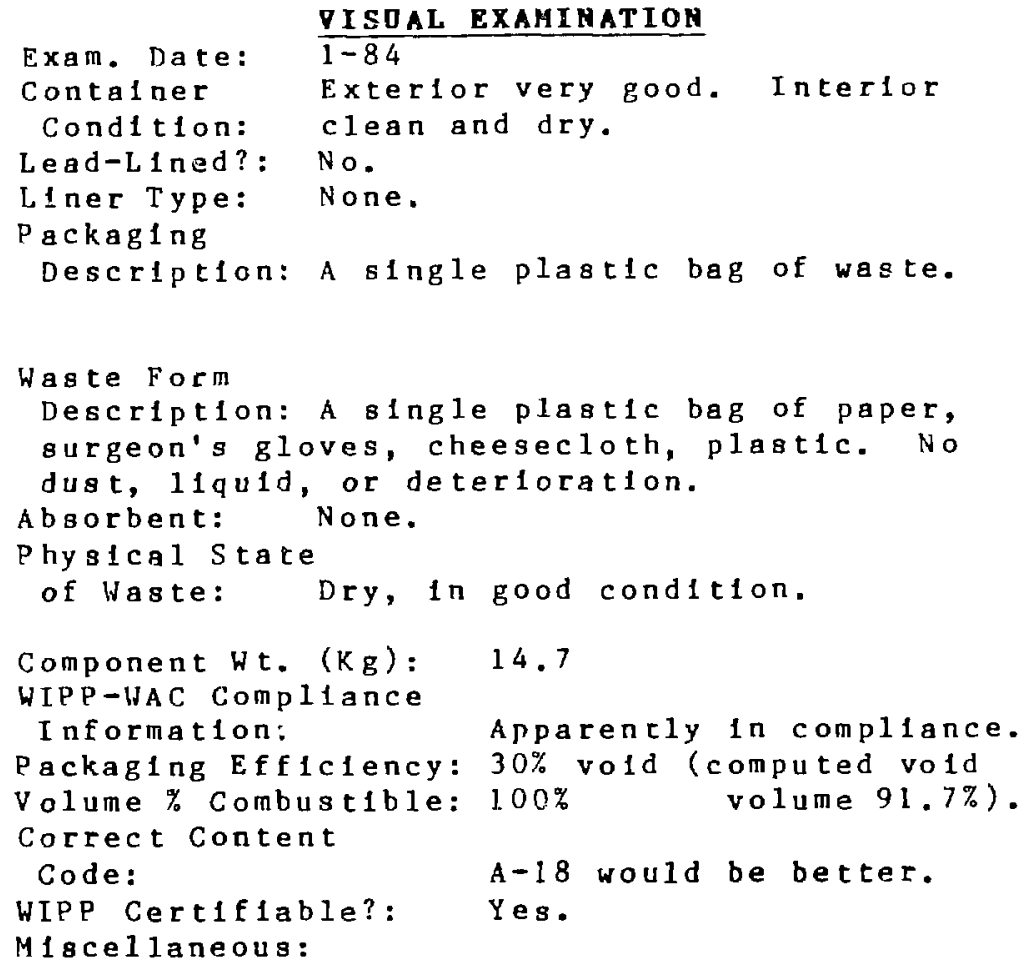




\section{SUMHARY SHEET}

Waste Form Category: Mixed paper, plastics, rubbers, etc.

$\begin{array}{ll}\text { Contalner ID: } & B F B-92 \\ \text { Content Code: } & A-18 \\ \text { Contalner Wt. (Kg): } & 23.6 \\ \text { Original Assay (g): } & 7.7 \\ \text { Packaging Location: } & M S T-D O, \text { TA-5 } \\ \text { Rad1onuclide: } & 238 \text { Pu }\end{array}$

\section{RADIOGRAPHIC EXAMINATION}

Exam. Date: $\frac{\text { Rat }}{9-83}$

I Iner Type: None

Lead-Lined?: No

$P$ ackag $1 \mathrm{ng}$

Description: Cylindrical contalners in drum.

Low, uniform density. No clue as to specific contents.

Waste Form

Description:

Absorbent?: None.

Free L1qu1ds: None.

Compressed

Gasses: None.

Particulates: None observed.

Packaging

Efficlency: About $1 / 2$ full.

Volume \%

Combustible: Could not estimate.

Correct Con-

tent code:

WIPP

Cert1:1ab1e?: Yes.

M1scellaneous:
Age When Opened:

Contalner Type:

Code Deseription:

Surface Dose Rate:

Reassay ( $g$ ):

Date Packaged:
7 months

30-gal drum

M1xed paper, plast1cs, rubber, etc.

$7 \mathrm{~m} \mathrm{r}$

4.4

$1-24-83$

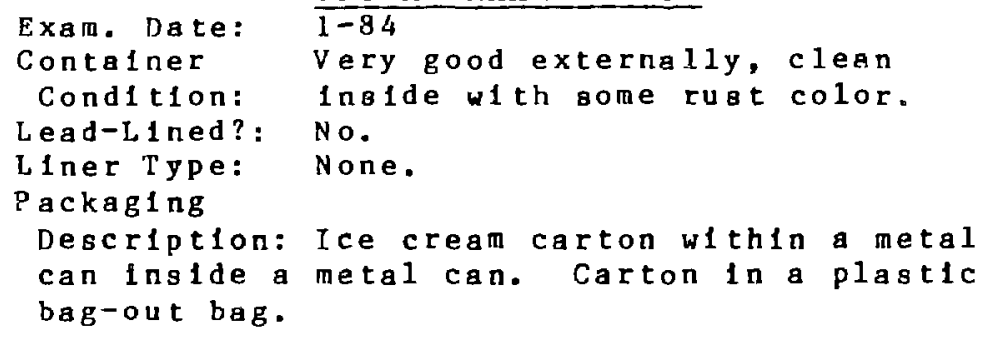

Exam. Date: Container

Cond1tion:

Lead-L 1 ned? :

L 1 ner Type:

$P$ ackag $1 \mathrm{ng}$

Description: Ice cream carton within a metal can Inside a metal can. Carton In a plastic bag-out bag.

\section{Waste Form}

Deacription: Inside one lce cream carton was $\mathrm{Al}_{2} \mathrm{O}_{3}$. Others contalned cheesecloth, leadwrapped vials, graphite solids.

Absorbent:

Physical State

of Haste: Dry, clean, some rusi color.

Component Wt. $(\mathrm{Kg}): \quad 7.7$

WIP -WAC Compliance

Information: Apparently in compliance*

Packaging Efficlency: $40 \%$ vold.

volume \% Combustible: $25 \%$

Correct content

Code: No. A-19 more approprlate.

WIPP Certifiable?: Yes.

Mlscellaneous: *Assign new waste code. 


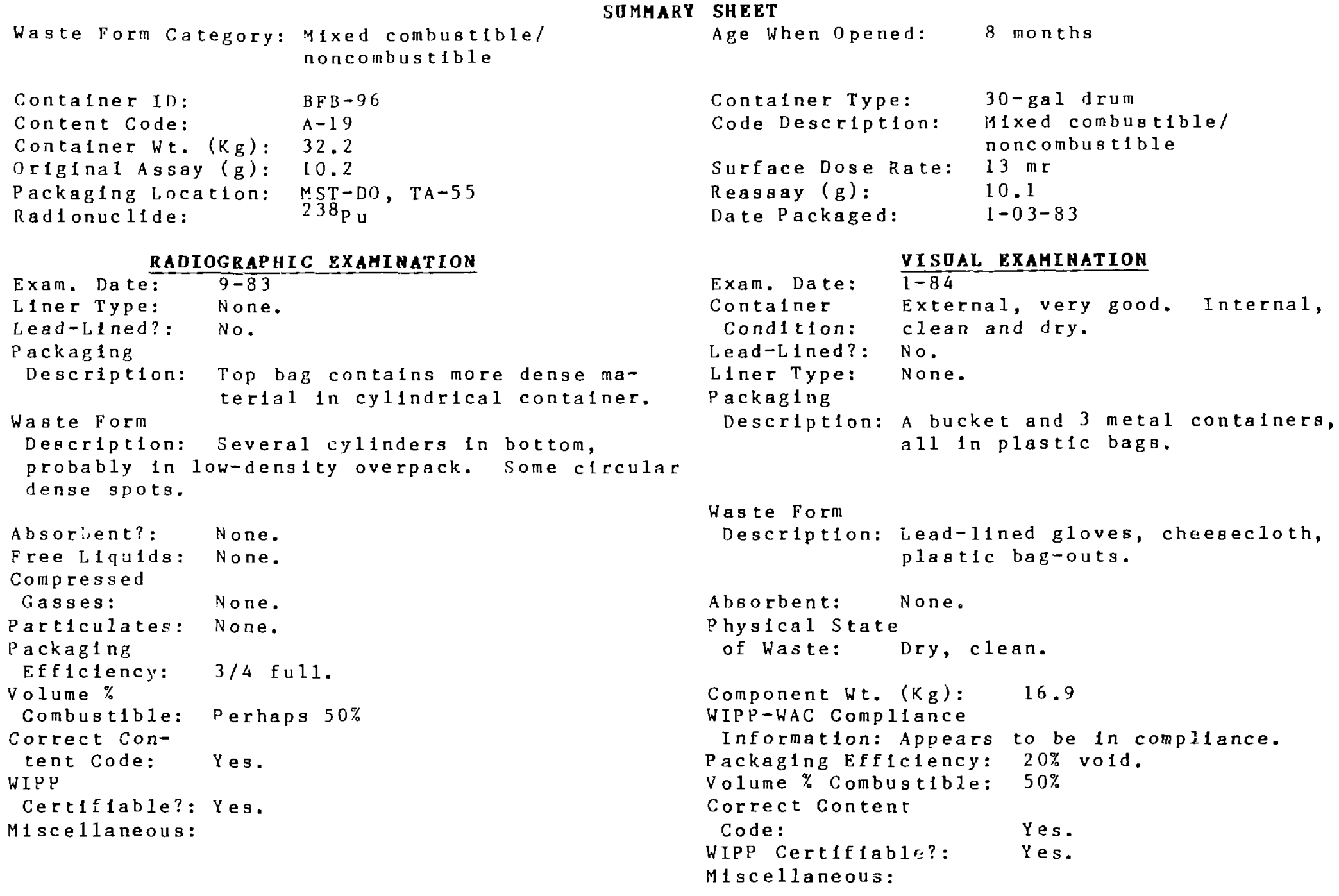




\section{SUHAART SHEET}

Waste Form Category: Mixed combusible/ noncombustible

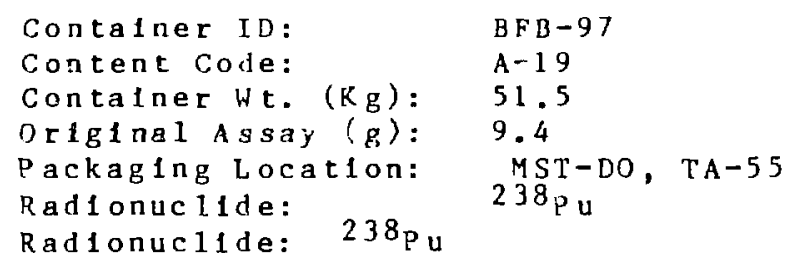

\section{RADIOGRAPHIC EXAMINATION}

Exam. Date: $9-83$

Liner Type: None.

Lead-Lined?: No.

Packaglng Several containers; one lying on Description: 1 ts side on top. Cylindrical dark blobs--probably metalilc vials or cannisters--

a 11 In a larger, less dense contalner.

Waste Form

Desertption:

Absorbent?: No.

Free L1quids: None.

Compressed

Gasses: None.

Particulates: Hone.

Packaging

Efficlancy: Probably $90 \%$ full.

Volume $\%$

Combustible: Probably $50 \%$.

Correct Con-

tent code:

Yes.

WIPP

Certiflable?: Yes.

M1scellaneous:
Age when Opened:

8 months

Contalner Type:

Code Description:

30-gal drum

MIxed combut 1 ble/

noncombus t 1 ble

Surface Doge Rate:

Reassay $(g)$ :

Date Packaged:

$15 \mathrm{mr}$

No record

$1-03-83$
Exam. Date:

Container

Cond 1 tion:

Lead-L i ned? :

Liner Type:

Packaging

Description: Metal containers holding baggedout metal containerb.

Waste Form Wire and plastic bottles (empty) Description: Inside bagged-out cans, deterlorated cheesecloth, Ziploc contalners, Al foll, rusty cans, hacksaw blade, small presgure vesse1, patit brushes, pliers.

Absorbent: None.

Phy 1 cal State

of Waste: Dry, rust colored.

Component Wt. $(\mathrm{Kg}): \quad 20.07$

WIPP-WAC Compliance

Information: Apparently in compliance.

Packaging Efficlency: $5 \%$ vold.

Volume\% Combustible: $35 \%$

Correct Content

Code :

Y es.

WIPP Certiflable?: Yes.

M1scellaneous: 


\section{SUMHART SHEET}

\begin{tabular}{|c|c|}
\hline Waste Form Category: & $\begin{array}{l}\text { M1xed combust } \\
\text { noncombust } 1 \text { b } 1\end{array}$ \\
\hline $\begin{array}{l}\text { Contalner ID: } \\
\text { Content Code: } \\
\text { Contalner Wt. (Kg): } \\
\text { Original Adsay ( } \mathrm{g}): \\
\text { Packaglng Location: } \\
\text { Radionucilde: }\end{array}$ & $\begin{array}{l}B F B-102 \\
A-19 \\
32 \\
3.4 \\
M S T-D O, T A-55 \\
238_{\mathrm{P} \mathrm{U}}\end{array}$ \\
\hline
\end{tabular}

\section{RADIOGRAPHIC EXAMINATION}

Exam. Date: $9-83$

Liner Type: None.

Lead-Lined? : No.

Packaging

Description: Plastic bags in drum.

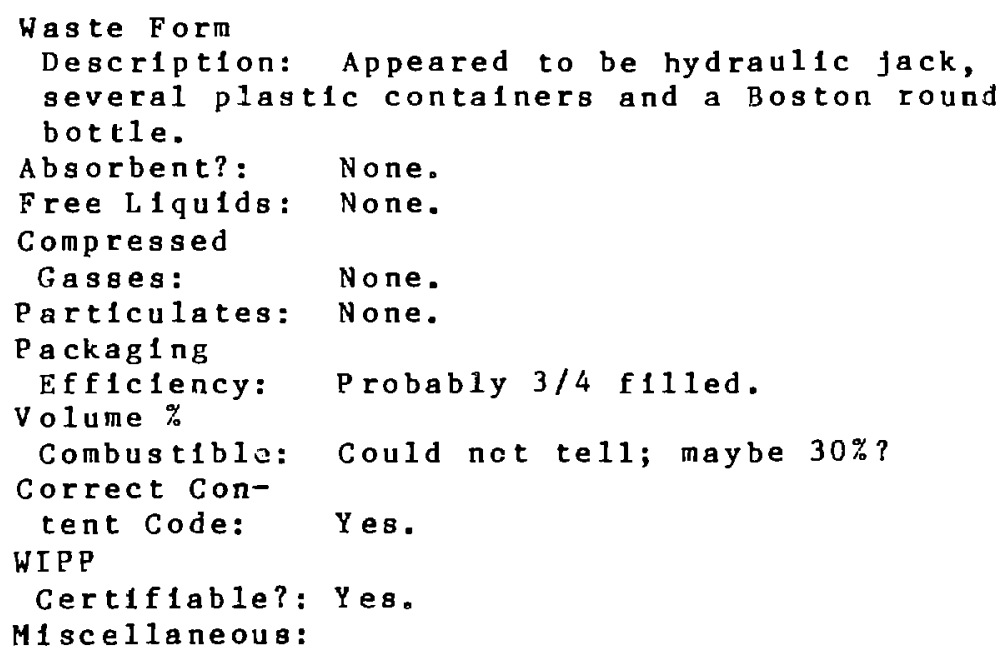

Age When opened: 7 months

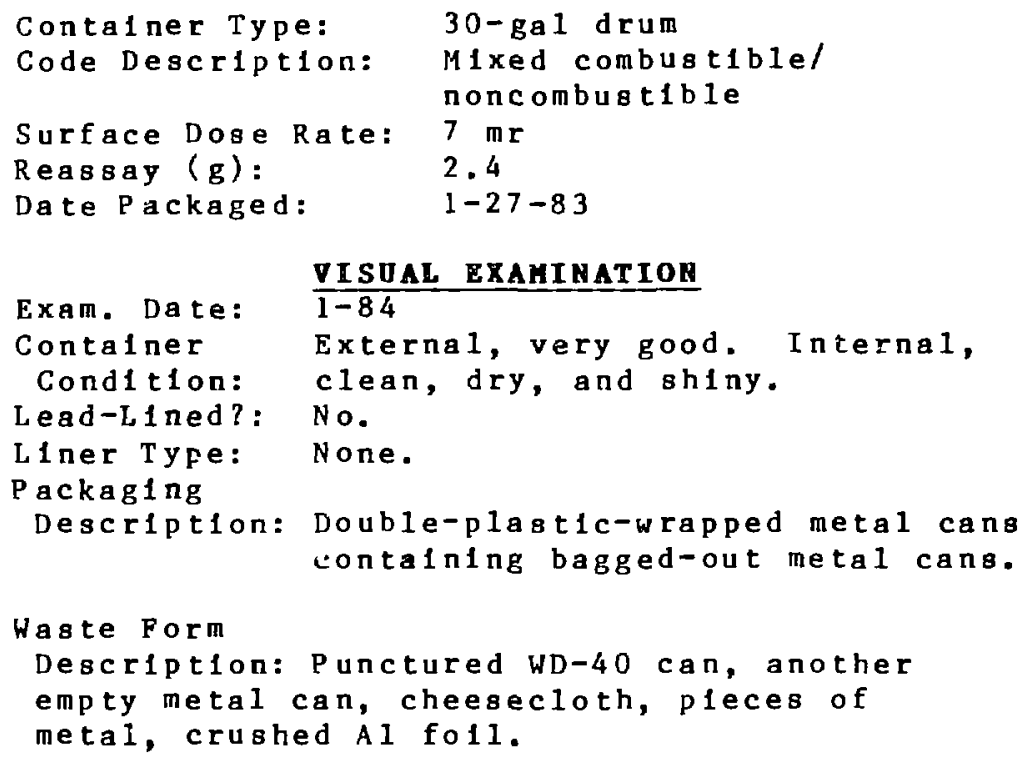




$\begin{array}{ll}\text { Waste Form Category: } & \begin{array}{l}\text { Mixed combust } \\ \text { noncombustible }\end{array} \\ & \\ \text { Contalner ID: } & \text { BFB-103 } \\ \text { Content Code: } & \text { A-19 } \\ \text { Container Wt. (Kg): } & 29 \\ \text { Original Assay ( g): } & 6.8 \\ \text { Packaging Location: } & \text { MST-DO, TA-5 } \\ \text { Radionucilde: } & 238 \text { Pu }\end{array}$

\section{RADIOGRAPHIC EXAMINATION}

Exam. Dete: $9-83$

Liner Type: None.

Lead-L1 ned?: No.

Packaging

Description: Cans in plastic bags, one hori-

zontal on top, 4 vertical on bottom.

\section{Waste Form}

Description:

\author{
Absorbent?: None. \\ Free Liquids: None. \\ Compressed \\ Gasses: \\ None. \\ Particulates: None. \\ Packaging \\ Efficlency: About $2 / 3$ ful1. \\ Volume \% \\ Combustible: Could not tell. \\ Correct Con- \\ tent Code: Probably. \\ WI P P \\ Certifiable?: Yes. \\ M1scellaneous:
}

\section{SUMHARY SHEET}

Age When Opened: 7 months

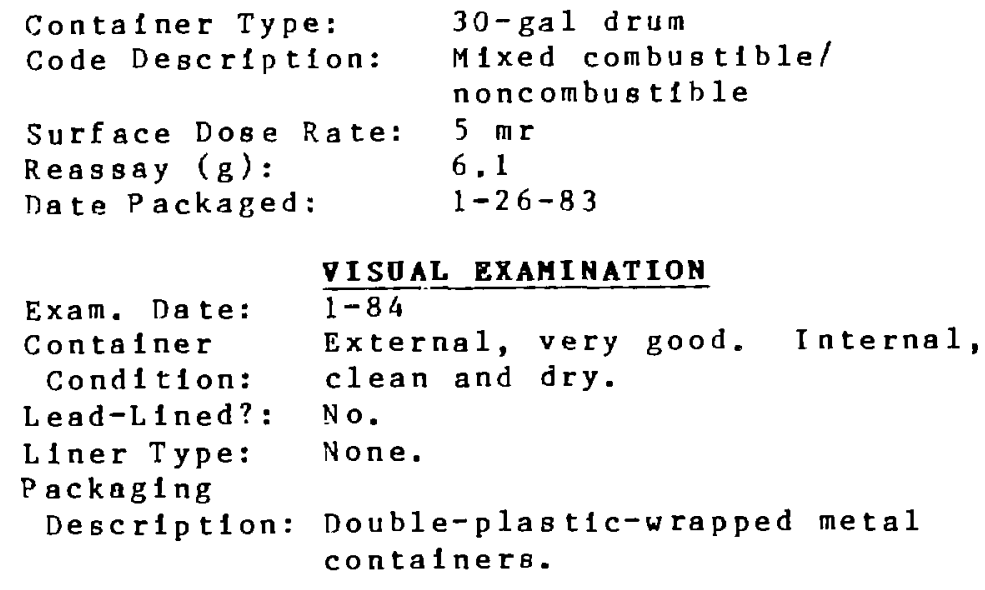




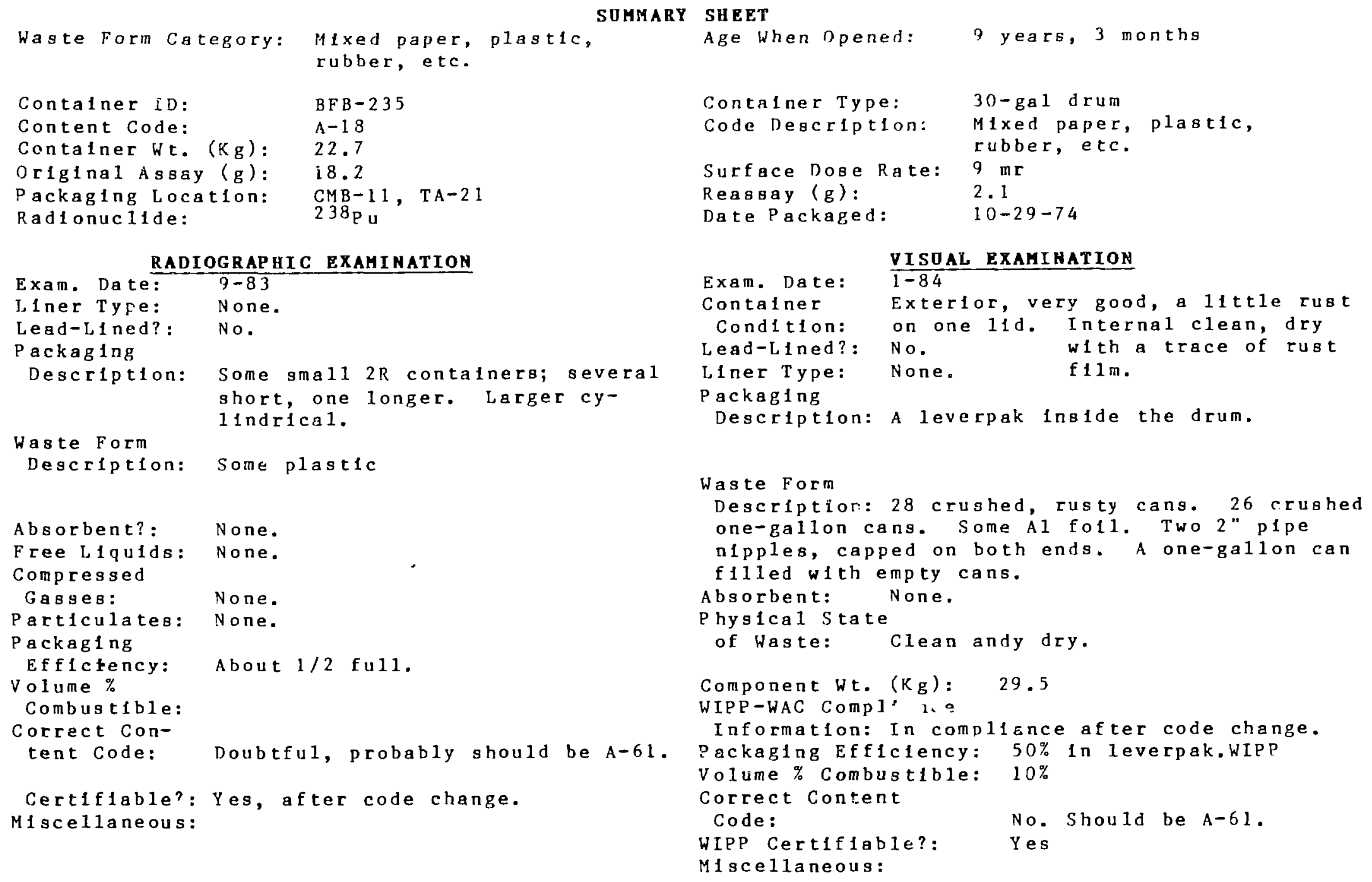




\section{SUMMARY SHEET}

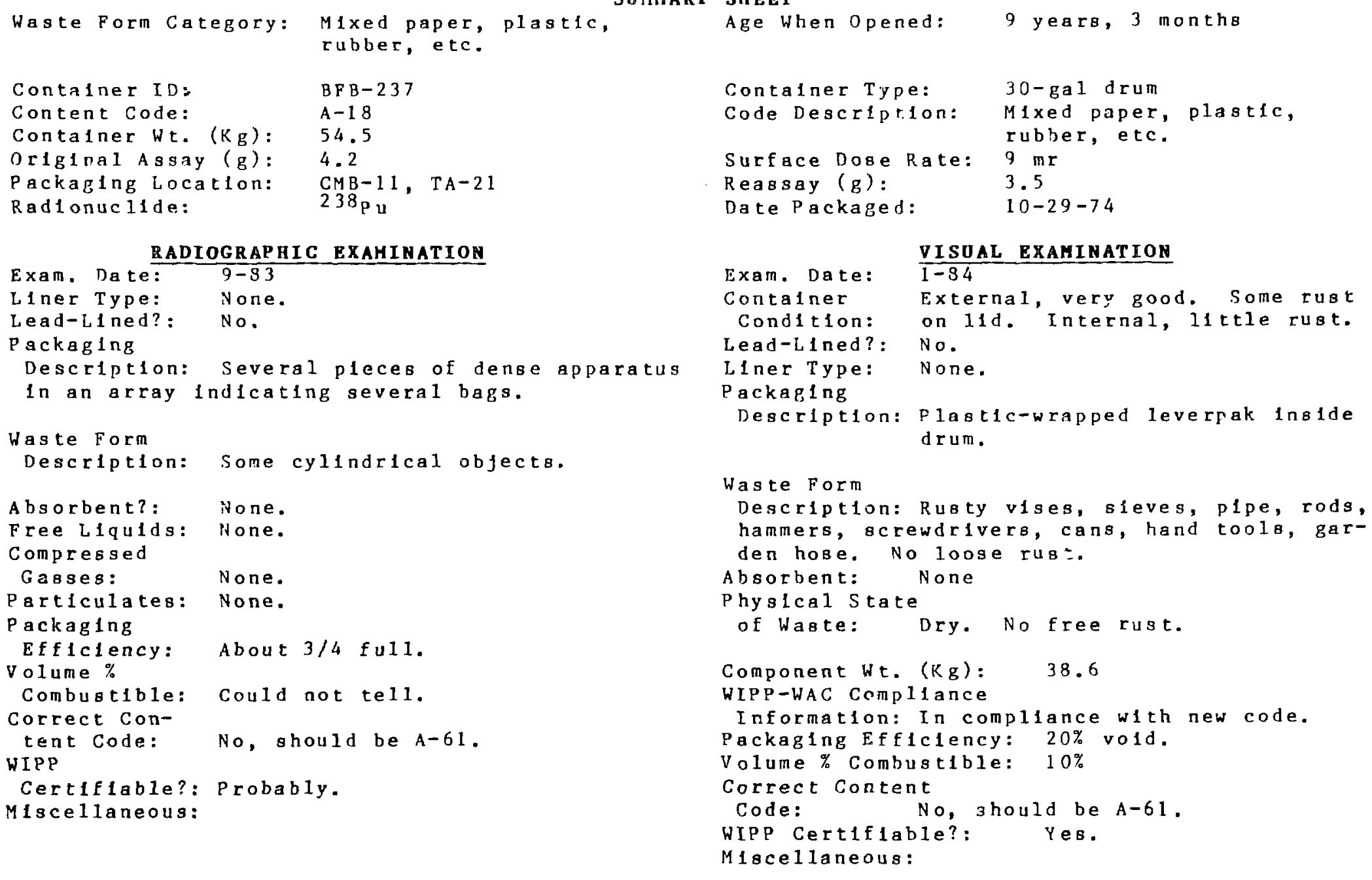




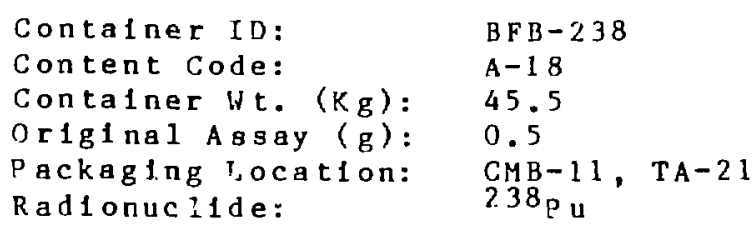

\section{RADIOGRAPHIC EXAMIHATIOH}

\section{Exam. Date: $9-83$}

Liner Type: None.

Lead-Lined? : No.

Packaging

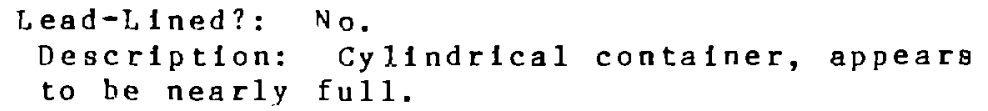

Age When opened:

Contalner Type:

Code Description:

Surface Dose Rate:

Reas8ay $(g)$ :

Date Packaged:

\section{SUAL RXAMINATION}

Exam. Date:

Contalner

Condition:

\section{$1-84$}

External, some rust on $11 d$ and drum, but still good. Internal, rusty inside both drum and leverpak.

Liner Type: None.

$P$ ackaging

Description: Leverpak inside a plastic bagout.

Waste Form

Description: 10 rusty containers, 5 presiure vessels, stainless door frame and gasket, 2 halves of a plastic window port, empty plastic bag-out stubs, 8 transfer cans, misc. pleces of rusty metal. (Continued below).

Absorbent: None.

Physical State

of Waste: Dry, very rugty.

Component wt. (Kg): 29.5

WIPP-WAC Compliance

Information: In compliance with new code.

Packaging Efficiency: $30 \%$ vold in leverpak. Volume \% Combustible: $10 \%$

Correct Content

Code: No, should be A-61.

WIPP Certiflable?: Yes.

Miscellaneous: Waste Form Dejcription Continued: After shaking and bang1ng, $0.98 \mathrm{~g}$ of rugt was collected. Only $4 \%$ was smaller than 200 micrometers, so it would meet WIPPWAC criteria. 


\section{SUHMARY SHEET}

Waste Form Category: M1xed paper, plastic, rubber, etc.

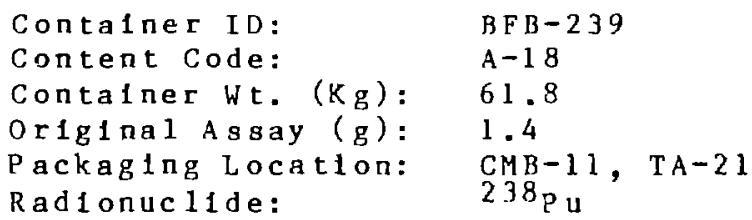

\section{RADIOGRAPHIG EXAHCNATION}

Exem. Date: 9-83

L Iner Type: None.

Lead-Lined?: No.

Packag $1 \mathrm{ng}$

Description: Plastic-bagged contalners of more dense materials.

Waste Form

Description: $2 R$ contalners? Small dril1-press

vise? Larger cyilidrical contalners.

\section{Absorbent?: None.}

Free L1qu1ds: None.

Compressed

Gasies: None.

Particulates: None.

Packaging

Efficlency: About $3 / 4$ filled.

Volume \%

Combustible: Appears to be $10 w--10 \%$ ?

Correct Con-

tent code:

No, should probably be $A-61$.

WIP P

Certiflable?: Yes, w1th code change.

Misce1laneous:
Age When Opened:

9 years, 3 months

Contalner Type: $\quad 30-g a 1$ drum

Code Description: Mixed paper, plastic,

Surface Dose Rate: $6 \mathrm{mr}$

Reassay ( $g): \quad 0.65$

Date Packaged: $\quad 10-29-74$

\section{Exam. Date: \\ Container \\ VISUAL ERAMINATION \\ Condition: \\ $-84$ \\ Lead-Lined?: No. \\ Liner Type: None. \\ Packagling \\ Description: P1astic-wrapped metal cans \\ contaling a variety of wastes.}

Haste Form

Description: plastics, metals, glass tubes, metal tubes, scrap metal deslcator, heat lamp, glass bottles, broken glass, metal tools.

Absorbent: None.

Physlcal State

of Waste: Clean and dry.

Component Wt. ( $\mathrm{Kg})$ : 45.9

WIPP-WAC Comp11ance

Information: In compliance after code change.

Packagling Efficiency: $5 \%$ vold.

Volume \% Combustible: $10 \%$

Correct content

Code: No, should be A-61.

WIPP Certifiable?: Yes.

M1scellaneous: 


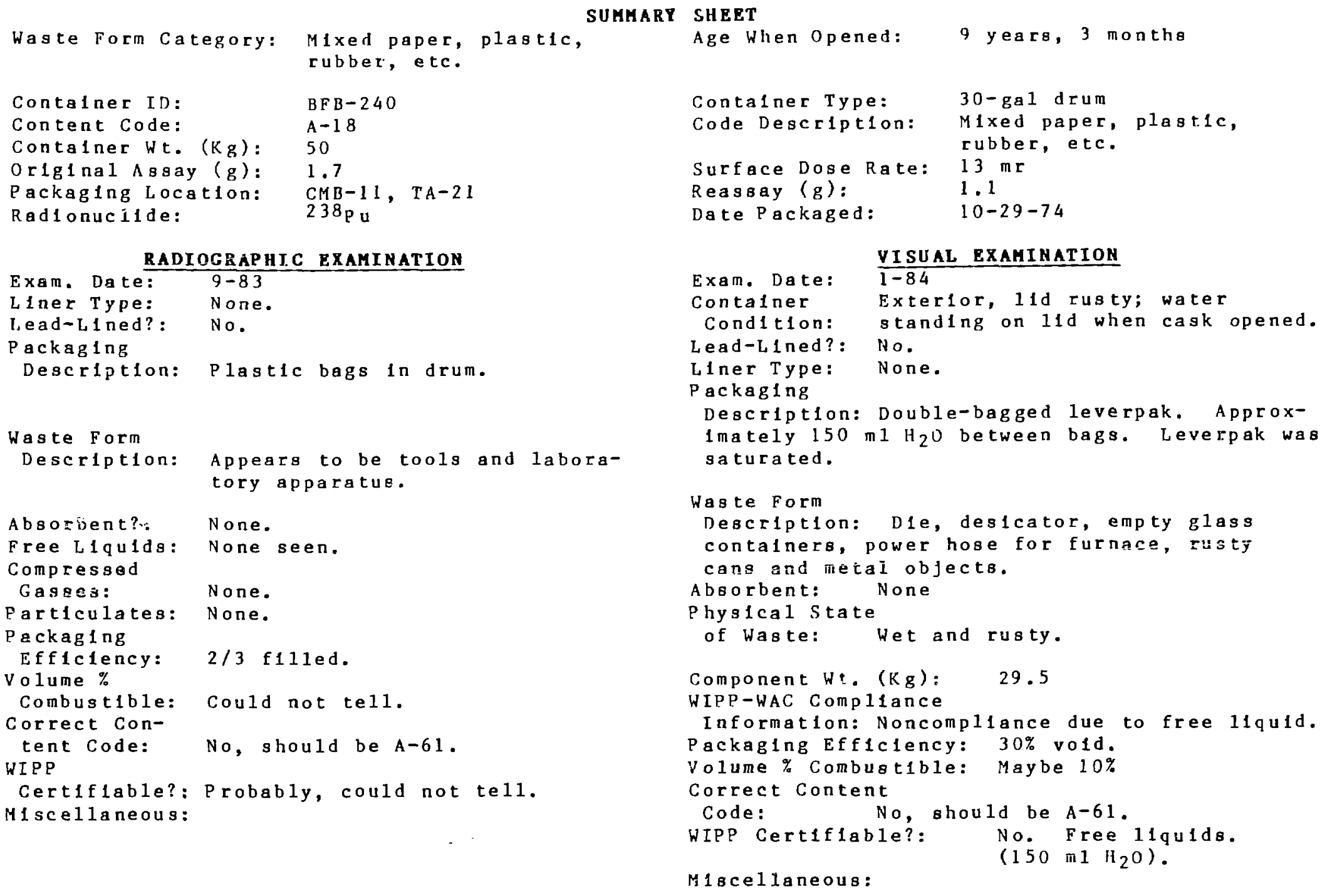




\section{SUHMARY SHERT}

Waste Form Category: Mixed paper, plastic, rubber, etc.

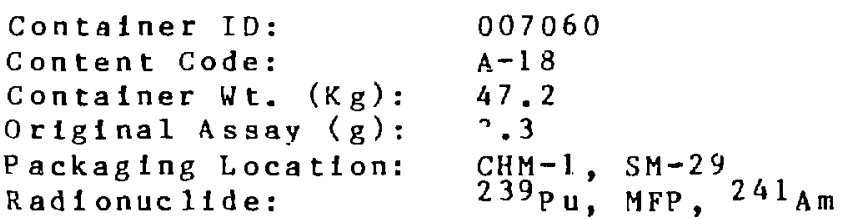

\section{RADI OGRAPHIC EXAHINATION}

Exam. Date: $9-83$

Liner Type: None.

Lead-Lined? : No.

ackaging

Description: This drum was not radiographed.

\section{Waste Form}

Description:

Absorbent? :

Free Liquids:

Compressed

Gases:

Particulates:

Packaging

Efficiency:

Volume \%

Combustible:

Correct con-

tent Code:

WIP P

Certiflable?:

M1 acellaneous:
Age When opened: 11 montho

$\begin{array}{ll}\text { Contalner Type: } & 55-g a 1 \text { drum } \\ \text { Code Description: } & \text { Mixed paper, plastic, } \\ & \text { rubber, etc. }\end{array}$

Reassay $(\mathrm{g}): \quad 3.56$

Date Packaged: $2-14-83$

\section{Exam. Date: $1-84$ LAMTHAT}

Container External, very good. Internal, Condition: clean and dry, no dents, no dust.

Lead-Lined?: No.

Liner Type: None.

Packaging

Description: Large 5-mil plastic bag contained the waste inside the drum.

Waste Form

Description: Gloves, rags, empty plastic vial, ahoe covers, empty lce cream contalnera, organic room trash.

Absorbent: None.

Phys 1 ca 1 State

of Haste: Dry and clean.

Component Wt. ( $\mathrm{Kg})$ :

19.7

WPP-WAC Compliance

Information: Appears to be in compliance.

Computed Vold Volume: $91.1 \%$

Packaging Efficlency: $5 \%$ vold.

volume \% Combutible: $100 \%$

Correct Content

Code:

Yes.

WIPP Certiflable?: Yes.

M Lcellaneous: 
Waste Form Category: Mixed paper, plast1c, zubber, etc.

$\begin{array}{ll}\text { Conta1ner ID: } & 007226 \\ \text { Content Code: } & A-18 \\ \text { Conta1ner Wt. (Kg): } & 48.1 \\ \text { Origl:al Assay (g): } & 0.4 \\ \text { Packag1ng Location: } & \text { CHM-1, SM-29 } \\ \text { Radionuclide: } & 239 \mathrm{Pu}, \mathrm{MFP}, 241 \mathrm{Am}\end{array}$

\section{$\frac{\text { RADIOGRAP HIC EXAMINATION }}{9-83}$}

\begin{abstract}
Exam. Date:
L Iner Type:

Lead-Lined?

Packag $1 \mathrm{ng}$

Desertiption:

Waste Form

Description:
\end{abstract}

No.

Var1able density suggesting multiple bags of trash.

Organic trash, plus pipes or tubes about 30 1nches 1 ong.

Absorbent?: None.

Free L1qu1ds: None.

Compressed

$\mathrm{G}$ asses:

None.

Particulates: None.

Packaging

Effictency

Volume \%

Combustible: Frobably $80 \%$.

Correct Con-

tent Code:

Yes.

WI P P

Certifiable?: Yes.

MIsce11aneous:

\section{SUMAARY SHEET}

Age When Opened:

11 months

Contalner Type:

55-gal drum

Code Description: Mixed paper, plastic, rubber, etc.

Surface Dose Rate: $2 \mathrm{mr}$

Reassay ( $g$ ): $\quad 0.43$

Date Packaged:

$2-14-83$

\author{
VISOAL EXAMINATION \\ Exam. Date: $1-84$ \\ Contalner \\ Condition: \\ Lead-L 1 ned? : \\ L 1 ner Type: \\ External, very good. Internal, \\ clean and dry. \\ Packagirig \\ Description: Plastic-bagged drybox trash.
}

Waste Form

Description: Enpty ice cream cartons, glass vials, squeeze bottles, paper and rubber, bagged-out in several separate plastic bags.

Absorbent: None.

Phy g ical State

of Waste: Dry.

Component Wt. ( $\mathrm{Kg})$ :

21.9

WIPP-WAC Comp1iance

Information: Apparently in compliance.

Packag1ng Efficlency: 5\% vold (computed vold)

Volume \% Combustible: $100 \%$ volume $92.6 \%$ )

Correct Content

Code:

Yes.

WIPP Certifiable?: Yes.

MIscellaneous: 


\section{SUHMARY SHEET}

Waste Form Category: Leached process residues

$\begin{array}{ll}\text { Container LD: } & 010108 \\ \text { Content Code: } & \mathrm{A}-25 \\ \text { Container Wt. (Kg): } & 56.8 \\ \text { Original Assay (g): } & 80(239 \mathrm{Pu}), 0.3 \quad(238 \mathrm{Pu}) \\ \text { Packag1ng Location: } & \text { CMB-11, TA-55 } \\ \text { Radionuclide: } & \text { Mixed as shown }\end{array}$

\section{RADIOGRAPHIC EXAMINATION}

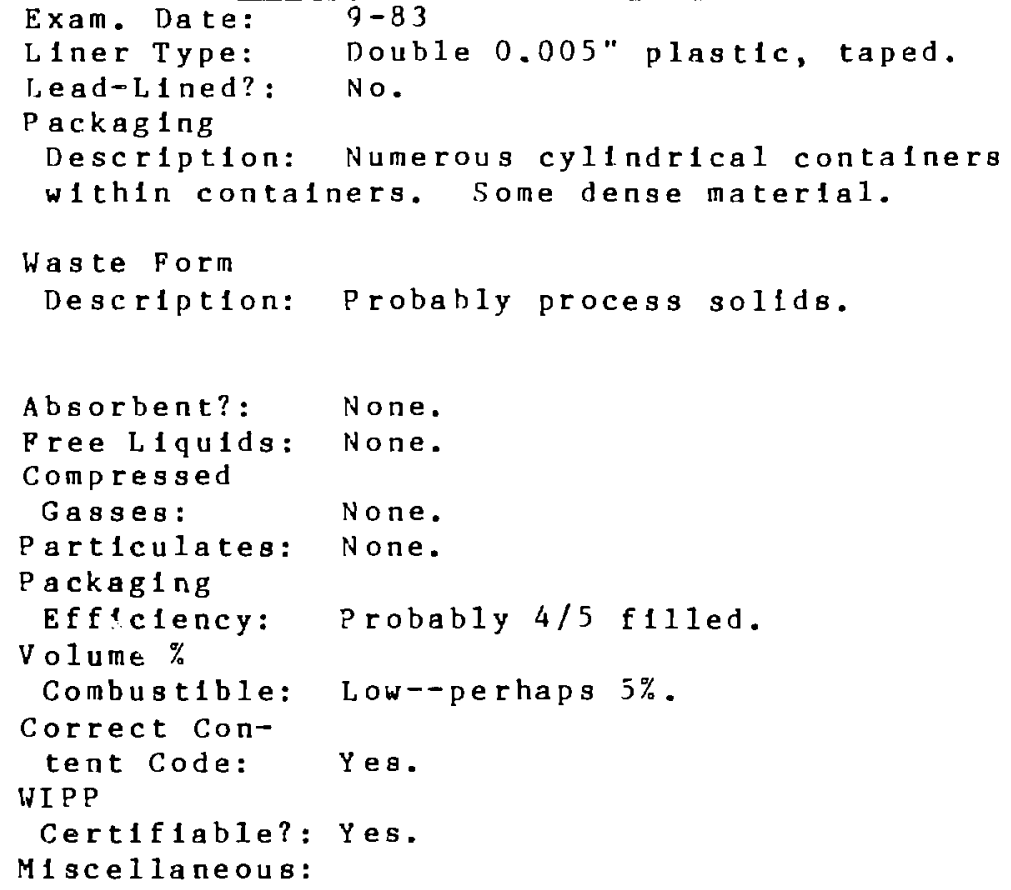

Age When opened:

25 months

$\begin{array}{ll}\text { Contalner Type: } & 55-g a 1 \text { drum } \\ \text { Code Description: } & \text { Leached process residues } \\ \text { Surface Dose Rate: } & 13 \text { mr } \\ \text { Reassay (g): } & 53(239 \mathrm{Pu}), 0.0(238 \mathrm{Pu}) \\ \text { Date Packaged: } & 7-02-81\end{array}$

\section{VISUAL EXAMINATION}

Exam. Date: $1-84$

Contalner External, very good; Internal, Condition: clean and dry.

Lead-Lined?: No.

Liner Type: Double $0.005 "$ plastlc, taped.

Packaging

Description: 14 units - e1ther can 1n bag, or can in can, or double-plastic-bagged.

\section{Waste Form}

Description: Sol1ds such as $\mathrm{CaCl}_{2}$, hydroxide cake, ceramic ch1ps, 1 double-bagged "damp" dark powder.

Absorbent:

Physical State

of Waste: Dry, except for damp powder.

Component Wt. (Kg): 33.44 WIPP-WAC Comp11ance

Information: Apparently in compliance.

Packaging Efficlency: $25 \%$ vold.

Volume \% Combuatible: $5-10 \%$

Correct Content

Coda:

Yes.

WIPP Certiflable?: Possibly.

Miscellaneous: 


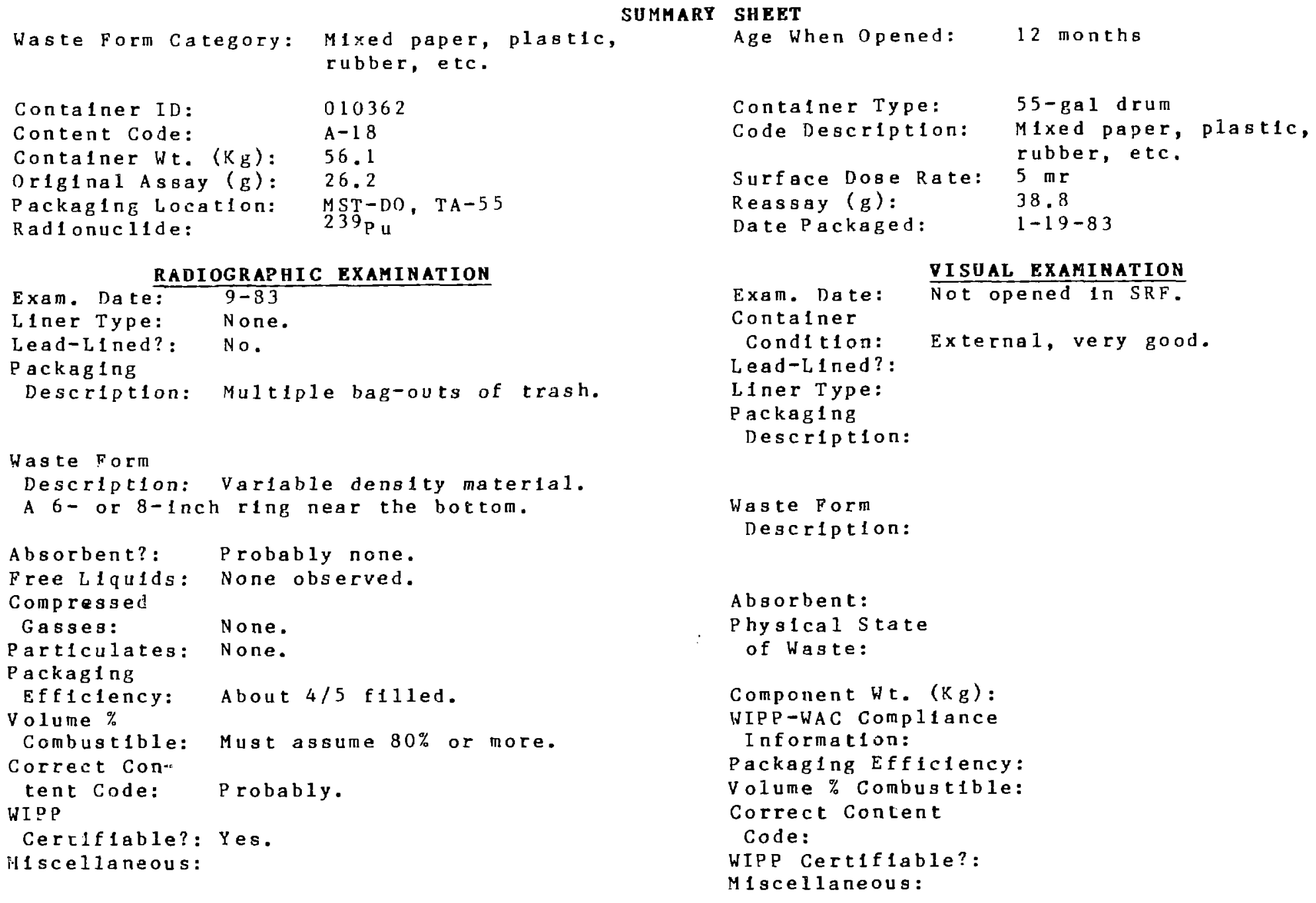




\section{SUMMARY SHEET}

Waste Form Category: Leached process residues

$\begin{array}{ll}\text { Container ID: } & 010411 \\ \text { Content Code: } & \text { A-25 } \\ \text { Contaner Wt. (Kg): } & 58.5 \\ \text { Original Assay (g): } & 186 \\ \text { Packaging Location: } & \text { MST-DO, TA-55 } \\ \text { Radionuclide: } & 239 \text { Pu }\end{array}$

\section{RADIOGRAPHIC EXAMINATINA}

Exam. Date:

Liner Type: Probably .005" plastic.

Lead-Lined?: No.

Packag1ng

Description: Cylindrical contalners (6).

Smaller one on bottom more dense.

Waste Form

Description: Belleved to be process solids.

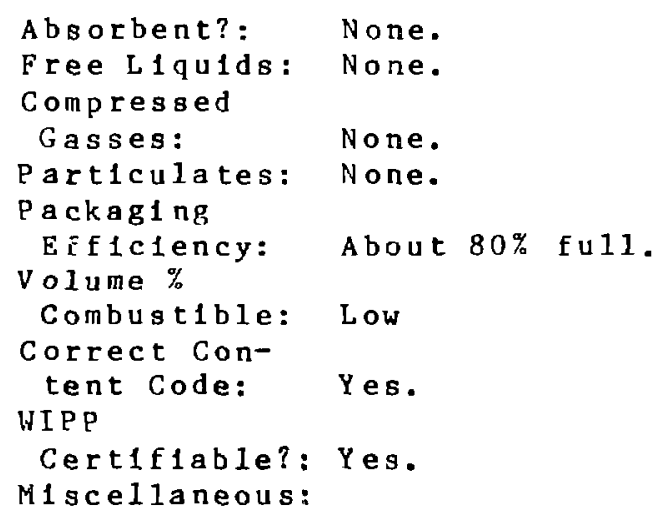

\section{Age when opened: 12 montho}

Contalner Type: 55-gal drum

Code Description: Leached process residues

Surface Dose Rate: $24 \mathrm{mr}$

Reassay $(\mathrm{g})$ : $\quad 132$

Date Packaged: $\quad$ l-27-83

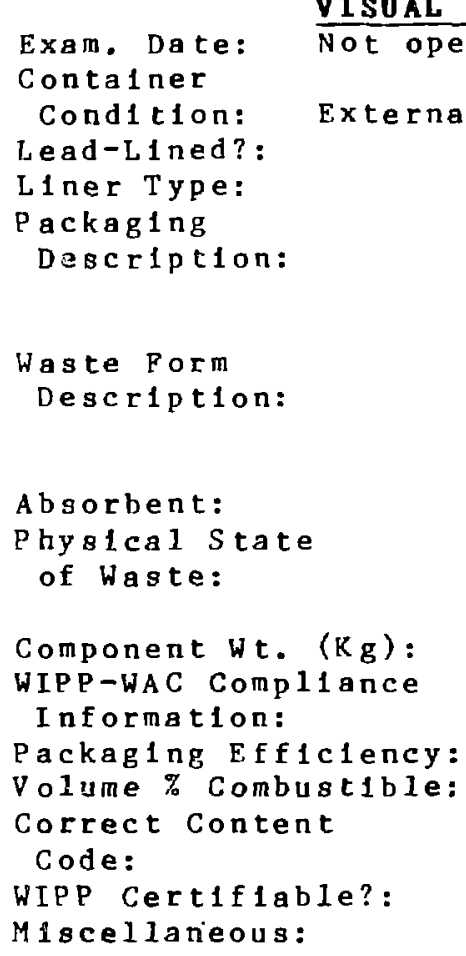




\section{SOHAARY SHEET}

Waste Form Category: Other scrap metals

$\begin{array}{ll}\text { Contalner ID: } & 010435 \\ \text { Content Code: } & A-52 \\ \text { Contalner Wt. (Kg): } & 84.9 \\ \text { Origlnal Assay ( } g): & 38 \\ \text { Fackaglng Location: } & \text { MST-Do, TA-55 } \\ \text { Radionuclide: } & 239 \text { Pu }\end{array}$

\section{RADIOGRAPBIC EXAHINATIOA}

$\begin{array}{ll}\text { Exam. Date: } & 9-83 \\ \text { Liner Type: } & \text { Two .005: plastic bags } \\ \text { Lead-Lined?: } & \text { No. } \\ \text { Packaging } & \\ \text { Description: Multiple bags and cans. }\end{array}$

Waste Porm

Description: Bag of dense material near top.

6 or 8 tubes in a cylindrical contalner. Large mashed can on bottom.

Absorbent? : None.

Free Liquids: None.

Compressed

Gasses: None.

Particulates: None.

Packaging

Efficiency: About $4 / 5$ filled.

Volume \%

Combustible: Quite low.

Correct Con-

tent Code:

WI PP

Certiflable?: Yes.

M1scellaneous:

Probubly.
Age When Opened: 12 months

Contalner Type: 55-gal drum

Code Description: Other acrap metals

Surface Dose Rate: $2 t$ mr

Reassay $(g)$ :

Date Packaged: $\quad 1-20-83$

\section{VISUAL EXAPINATION}

Exam. Date: $1-84$

Container External, very good. Internal, Condition: clean and dry.

Lead-L1ned?: No.

Liner Type: Double plastic bags.

Packag1ng

Description: Multiple bags in a drum.

Waste Form

Description: Smashed, rusty cans, 2 pieces of plpe, mo1st ílter cake (nofree liquid).

Fine filtering ald.

Absorbent: None.

Phys Ica 1 State

of Waste: Dry. The f11tering a1d was $35.4 \%$

of total welght; $1 \mathrm{t}$ was all<70 m1crometers.

Component Wt. (Kg): 72.4

WIPP-WAC Compliance

In formation:

Packaging Efficiency:

Volume\% Combustible:

Does not comply.

Correct Content

$\begin{array}{ll}\text { Code: No, should be } A-52, A-55, \text { \& } A-61 . \\ \text { WIPP Certiflable?: } & \text { No. * } \\ \text { Miscellaneous: } & \text { *Fine flitering ald }\end{array}$

to be gtabt11 


$\begin{array}{ll}\text { Waste Form Category: } & \begin{array}{l}\text { Slag and porc } \\ \text { crucibles }\end{array} \\ & \\ \text { Container ID: } & 010494 \\ \text { Content Code: } & \mathrm{A}-47 \\ \text { Contalner Wt. (Kg): } & 69.8 \\ \text { Origlnel Assay (g): } & 198 \\ \text { Packaging Location: } & \text { MST-Do, TA-5 } 5 \\ \text { Radionuclide: } & 239 \mathrm{Pu}\end{array}$

\section{RADIOGRAPHIC ERAHTHATION}

Exam. Date: $9-\overline{33}$

Liner Type: Probably .005" p1astic

Lead-Lined?: No.

P ackaging

Description: Cylindrical containers within

cylindrical containers.

Waste Form

Description: 4 contalners, quite dense.

Would not be able to ldentify slag \& crucibles

whout prlor knowledge cf contents.

Absorbent?:

None.

Free Liquids: None.

Compressed

Gasses:

None.

Particulates: None.

Packagfing

Eff 1 c 1

Volume \%

Combustible: Probably very low ( $<10 \%)$.

Correct Con-

tent Code:

WIP P

Certiflable?: Yes.

M1scellaneous:

\section{SUMHARY SHEET}

Age when Opened: 12 months

$\begin{array}{ll}\text { Contalner Type: } & 55-g a 1 \text { drum } \\ \text { Code Description: } & 51 a g \text { \& porcelain crucibles. } \\ \text { Surface Dose Rate: } & 7 \text { mr } \\ \text { Reassay (g): } & \text { Not done } \\ \text { Date Packaged: } & 1-19-83\end{array}$

VISUAL EXAHINATION

Container

Condition: Exterior, very good.

Lead-Lined?:

Liner Type:

Packaging

Description:

\section{Waste Form}

Description:

Absorbent:

Physical State

of Waste:

Component Wt. ( $\mathrm{kg})$ :

WIPP-WAC Compliance

I nf ormat 1 on:

Packaging Efficiency:

Volume \% Combustible:

Correct Content

Code:

WIPP Certifiable?:

M1sce11aneous: 


\section{SUMHARY SHEET}

Waste Form Category: M1xed papez, plastic, rubber, etc.

$\begin{array}{ll}\text { Contalner ID: } & 010605 \\ \text { Content Code: } & A-18 \\ \text { Contalner Wt. (Kg): } & 64.7 \\ \text { Original Assay (g): } & 122 \\ \text { Packaging Location: } & \text { MST-Do, TA-55 } \\ \text { Radionucilde: } & 234 \text { u }\end{array}$

\section{RADIOGRAPHIC EXAHINATIOH} Exam. Dete: 9-83

Liner Type: .005" plastic bag.

Lead-Lined?: No.

Packaging

Description: No record of radiograph.

\section{Waste Form}

Description:

Absorbent?:

Fr ze L 1qu1ds:

Conpressed

Gasses:

Particulates:

Packaging

Efficlency:

Volume \%

Combut 1 ble:

Correct Con

tent code:

WIPP

Certiflable? :

MIscellaneous:
Age

Contalner Type:

Code Description:

55-ga1 drum

Mixed paper, plastic, rubber, etc.

Surface Doge Rate: $15 \mathrm{mr}$

Reassay ( $g$ ): 111

Date Packaged: $\quad 1-25-83$

\section{VISUAL EXAHIRATION}

Exam. Date:

Contalner

$1-84$

Condition:

Externa1, very good. Internal, clean and dry.

Lead-L1ned?: No.

Liner Type: .005" plastic.

Packag1ng

Description: Bagged-out 30-gal drum Inside a 55-ga1 drum.

Waste Form

vescifpt1oi: Rage in four cylindrical metal contalners, packed in 30-galion drum.

Absorjent: None.

Phy a 1 cal S tate

of Waste: clean and dry.

Component Wt. $(\mathrm{Kg}): \quad 7.9$

WIPP-WAC Compl1ance

Information: Apparently in compliance.

gackaging Efficlency $80 \%$ vold (computed vold

Volume \% Combustible $100 \%$ volume $97.1 \%$

Correct Content

Code:

OK, hyt could be $A-15$.

WIPP Certffiable?: Yes.

Hiscellaneous: 


\section{SUMHARY SHEET}

Waste Form Category: Other Noncombustibles

Age When Opened: 11 months

Container I D:

010645

Content Code:

Contalner $W t,(K g): \quad 88.1$

Orlginal Assay (g): 108.3

Packag1ng Location: MST-DO, TA-55

Rad 1 onuc 11 de:

$$
239 \mathrm{Pu}
$$

\section{RADI OGRAP İIC EXAHINATION}

Exam. Date: $\frac{\text { Ran }}{9-83}$

Liner Type: None.

Lead-ílned?: No.

$P$ ackag $1 \mathrm{ng}$

Description: Multiple plasilc bage of non-

combustibles. Bottom third contains more

derise objecta.

Waste Form

Description: No recognizable shapes.

Absorbent?: None.

Free L1qu1ds: None.

Compressed

None.

Gasses:

Particulates: None.

Packag $1 \mathrm{ng}$

Efficlency: About $90 \%$ filled.

Volume \%

Combustible: Probably 1ow.

Correct Con-

tent Code: Yes.

WIPP

Certifiable?: Yes.

M1scellaneous:

Container Type: 55-gal drum

Code Description: Other Noncombustibles

Surface Dose Rate: $3 \mathrm{mr}$

Reasвay $(g)$ : 116.8

Date Packaged: $\quad 1-26-83$

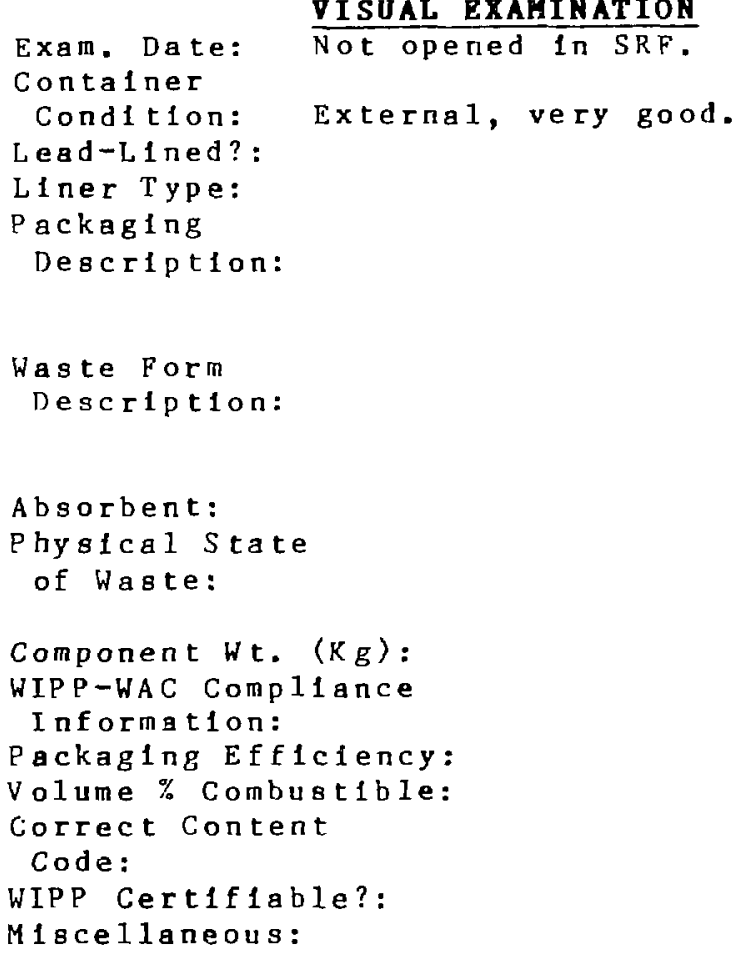

M Isce 11 aneous: 
Waste Form Category: Plastic Materials

Conta1ner I D:

Content Code:

Container Wt. ( $\mathrm{kg})$ :

Original Assay (g):

Packaging Location:

Radionuc 11 de:

$$
\begin{aligned}
& 010753 \\
& \text { A-I } 6 \\
& 70 \\
& 46 \\
& \text { MST-DO, TA-55 } \\
& 239 \text { P }
\end{aligned}
$$

\section{RADIOGRAPHIC EXAHINATION}

Exam. Date: 9-83

Liner Type: .005" plastic, taped to drum.

Lead-L1ned?: No.

Packaging

Description: Bagged-out 30-gal drum ingide a 55-gal drum.

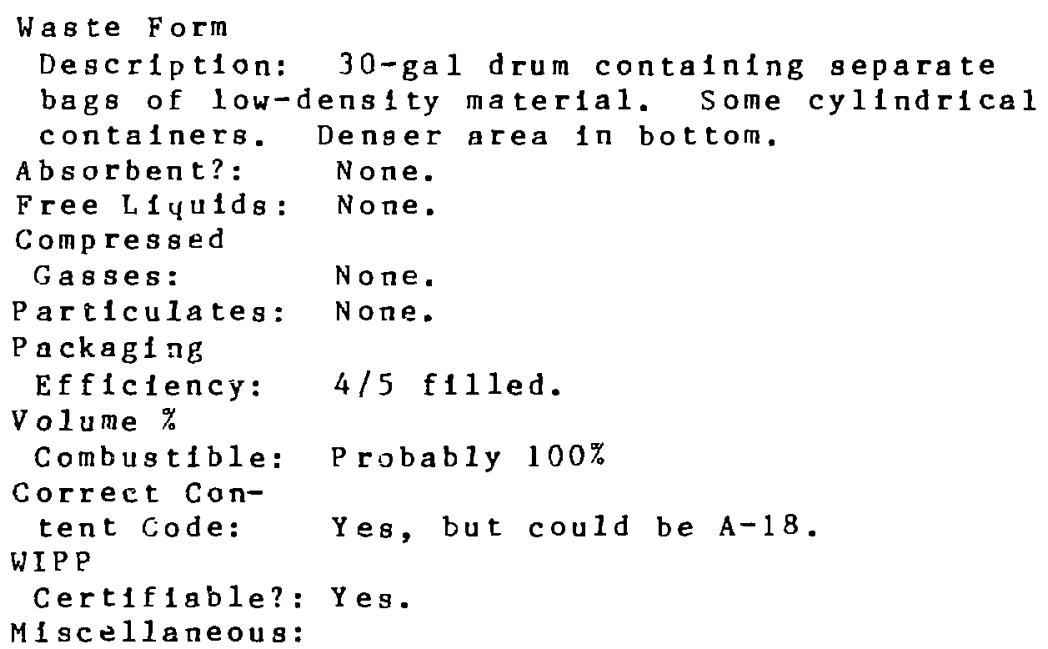

\section{SUMART SHEET}

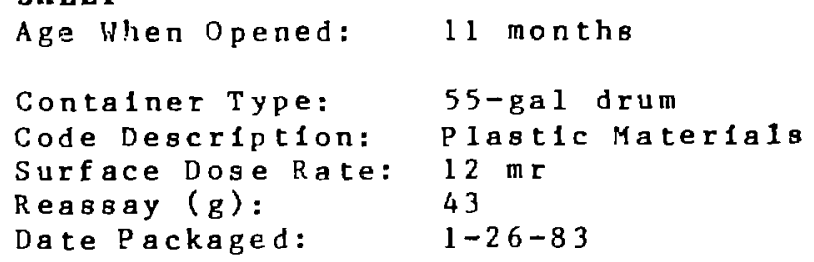

Exam. Date:

Container

Cond 1 tion:

Lead-Lined?:

L 1 ner Type:

Packaging

Description:

\section{VISUAL EXAHINATION}

\section{$1-84$}

External, very good. Internal, clean and dry.

No.

$.005 "$ plastic.

Bagged-aut 30-gal drum ins1de of a $55-\mathrm{gal}$ drum.

Waste Form

Description: Plastic bag of empty plastic bottles, bag of paper filters. 30-gal drum contalned about 1 liter of loose, fine brown Absorbent: None. dust.

Physical $S$ tate of Waste: Dry. $36 \mathrm{~g}(0.6 \%)$ of the brown powder is $<200 \mathrm{micrometers,} \mathrm{but} \mathrm{waste} 1 \mathrm{~s}$ in Component $W t .(\mathrm{Kg}): 6.3$ compliance. WIPQ-WAC Compliance

Informat 1 on:

Packaging Efficiency: 25\% vold (computed vold Volume $\%$ Combustible: $100 \%$ volume $96.7 \%$ ) Correct Content

Code: OK, could be A-18. WIPP Certifiable?: Yes.

M1sce11aneous: 
Waste Form Category: Other combustibles

Container I D:

Content Code:

Container Wt. ( $\mathrm{Kg})$

Origlnal Assay $(\mathrm{g})$ :

Packaging Location:

Rad Ionuclide:

$$
\begin{aligned}
& 010756 \\
& \mathrm{~A}-60 \\
& 40.5 \\
& 0.0 \\
& \mathrm{CMB}-11, \mathrm{TA}-55 \\
& 44 \mathrm{Am}, 48 \mathrm{CF}, 249 \mathrm{Bk}
\end{aligned}
$$

\section{RADIOGRAPHIC EXAMINATION}

Exam. Date: $9-83$

Liner Type: .005" plastic.

Lead-Lined? : No.

Packaging

Description: Smaller drum (15-gal?) Inside

B 55-gal drum.

Waste Form

Description: Dense ring in bottom of smaller drum.

Absorbent?: None.

Free Liquids: None.

Compressed

Gasses:

None.

Particulates: None.

Pa ckaging

Effletency: 15-gal drum about $1 / 3$ filled.

Volume \%

Combustible: Probably at least $50 \%$

Correct Con-

tent code:

WI P P

Certifiable?: Yes.

M1scellaneous:

\section{SUMHARY SHEET}

Age When Opened: $\quad 30$ months

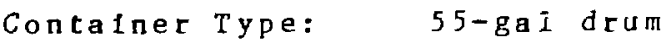

Code Description: Other combustibles

Surfacc Dose Rate: $5 \mathrm{mr}$

Reassay $(\mathrm{g}): \quad 0.0$

Date Packsged: 6-15-81

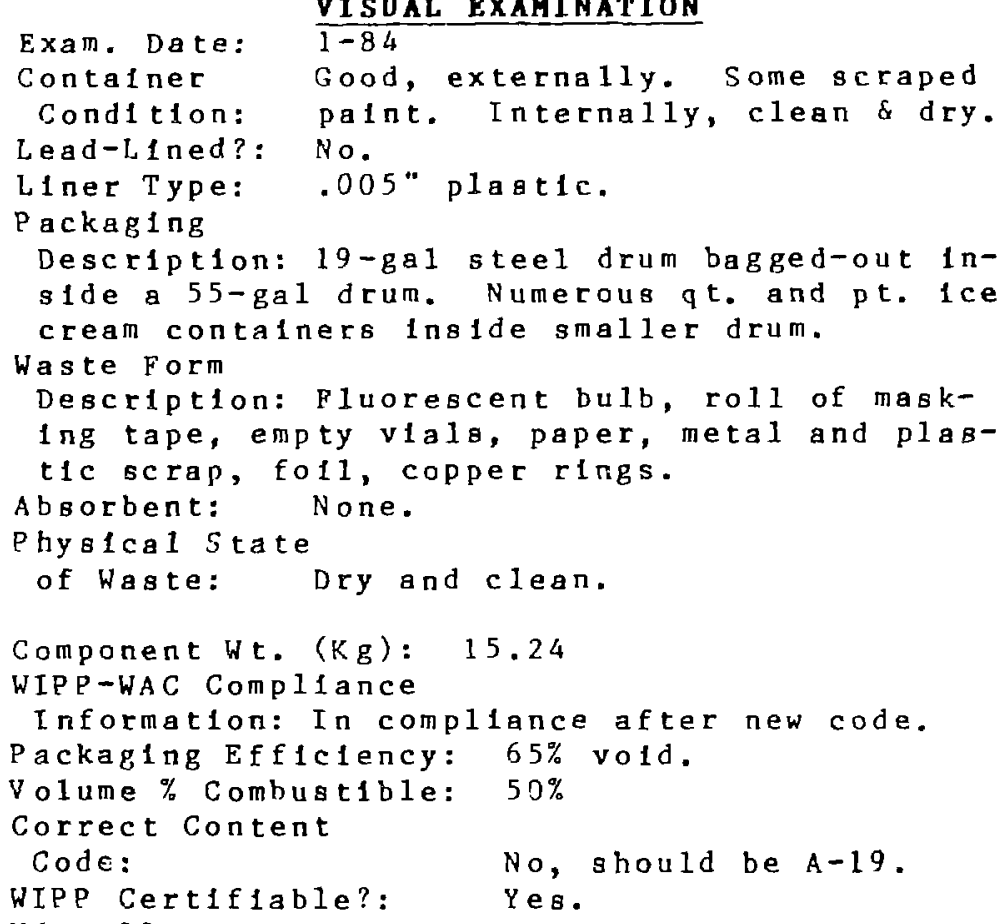




\section{SUMHARY SBEET}

Waste Foim Category: Combustible room decon waste

$\begin{array}{ll}\text { Contalner ID: } & 010761 \\ \text { Content Code: } & \text { A-14 } \\ \text { Conta1ner Wt. (kg): } & 49 \\ \text { Original Assay (g): } & 0.47 \\ \text { Packag1ng Location: } & \text { MST-Do, TA-55 } \\ \text { Radionuc11de: } & 239 \text { Pu }\end{array}$

\section{RADIOGRAPHIC EXAMIAATIOH}

Exam. Date: $9-83$

Linet Type: .005" plastic

Lead-L1 ned?: No.

Packaging

Description: Bagged trash.

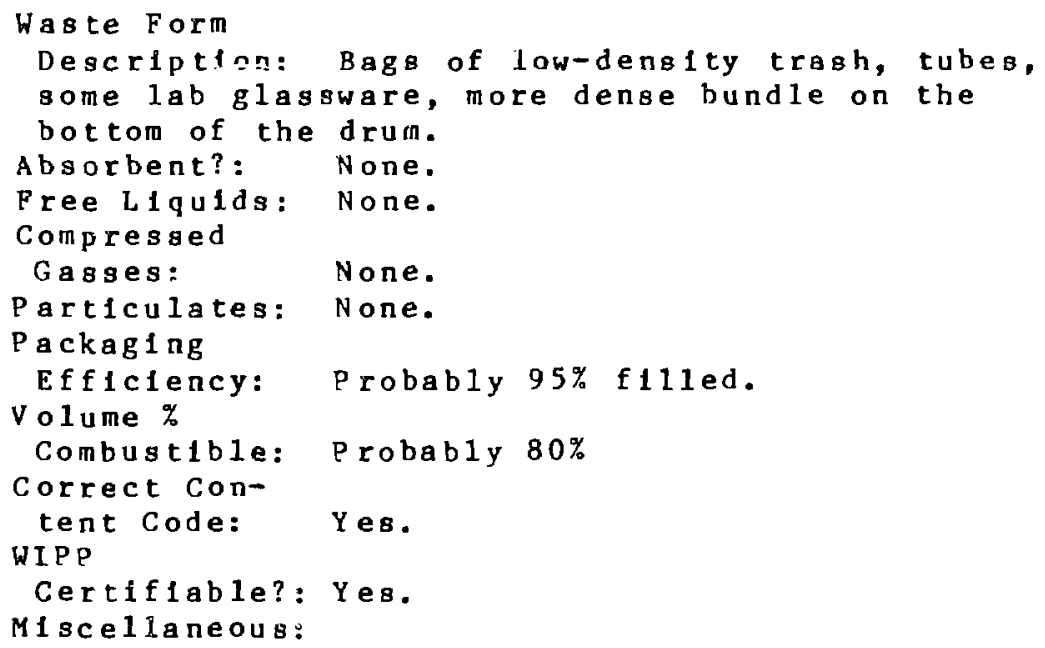

Age When opened: 11 months

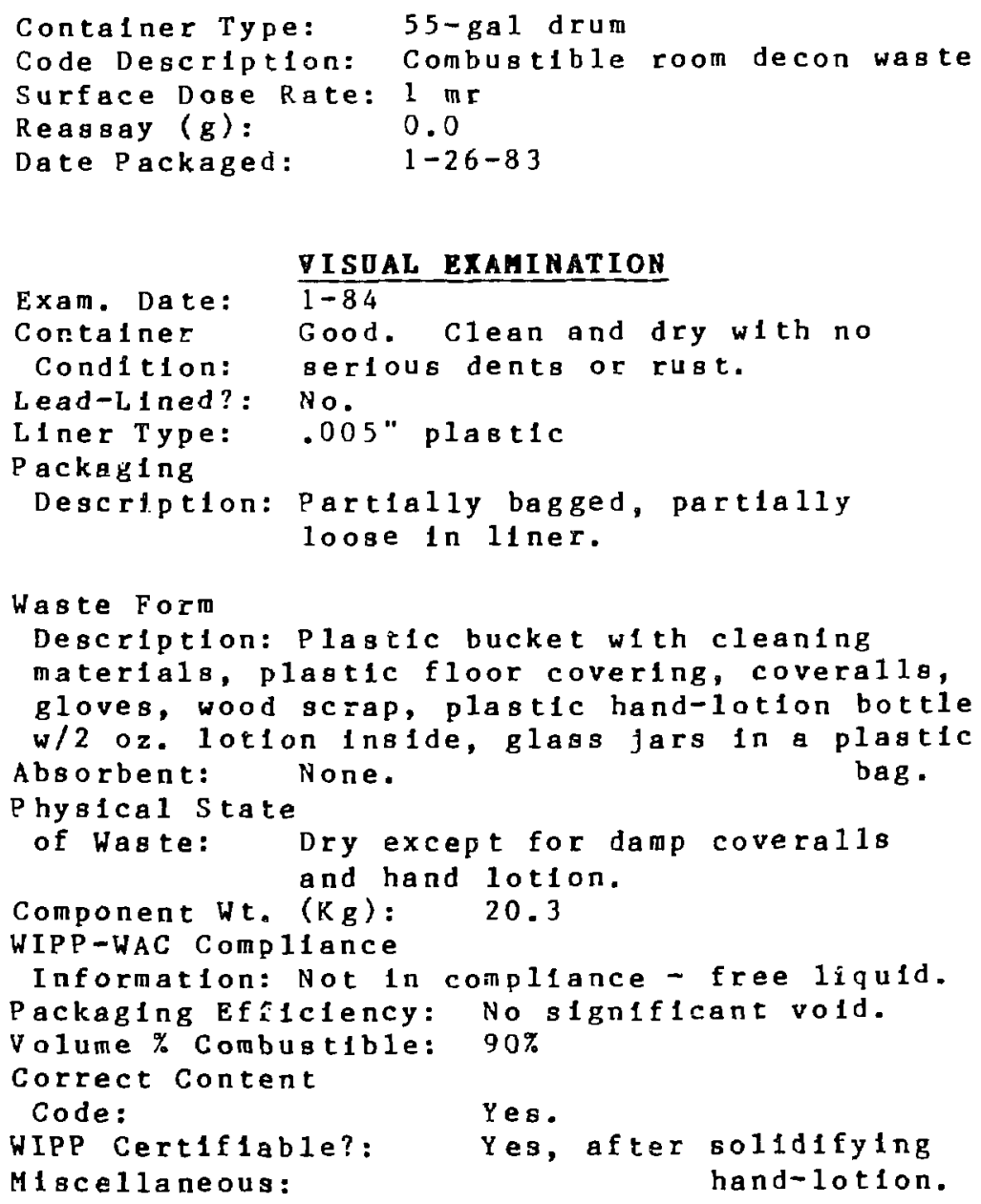


Waste Form Category: $\begin{aligned} & \text { Mixed combustible/ } \\ & \text { noncombustible }\end{aligned}$

$\begin{array}{ll}\text { Contalner ID: } & 010773 \\ \text { Content Code: } & \text { A-19 } \\ \text { Conta1ner Wt. (Kg): } & 50.4 \\ \text { Or1g1na1 Assay (g): } & 0.1 \\ \text { Packag1ng Locat1on: } & \text { MST-DO, TA-55 } \\ \text { Rad1onucilde: } & 239 \text { P }\end{array}$

\section{SUMHART SHEET}

Age when opened: 11 months

Container Type:

A res or bent?

Compreased

Gasses:

Particulates:

Packag $1 \mathrm{ng}$

Efficlency:

Volume\%

Combust 1 b1e:

Correct Con-

tent Code:

WIPP

Certif 1 able?:

M1sce 11 aneous:
Code Description:

Surface Dobe Rate:

Reassay (g):

Date Packaged:

\section{$\frac{\text { VISUAL EXAHINATION }}{1-34}$}

Exsm. Date:

Conta1ner

Condtion:

Lead-L1 ned?:

$\mathrm{I} 1$ ner Type:

packag $1,1 \mathrm{~g}$

Description: Partially bagged in plastic, partialiy loose in 11 ner.

\section{Waste Form}

Description: $5 "-30 "$ pipe sections, taped.

Included valves, a 1 so taped. Wet paper, raga, gloves, coveral1s, but no free 11 qu1d.

M1xed combustible/ noncombustib le

Apparently not done.

outs1de, very good. Inside, rustcolored, damp.

No.

$.005^{\prime \prime}$ plast1c.

bsorbent: None.

Physlcal State

of Haste: Wet, but no free 11qu1d.

Component Wt. (Kg): $\quad 31.8$

WIPP-WAC Compliance

Information: Apparently in compliance.

Packaging Efficiency: $20 \%$ void.

volume \% Combustible: $65 \%$

Correct Content

Code:

Yes.

WIPP Certiflable?: Yes.

M Isce 11aneous : 
Hagte Form ategory: Other combustibles

$\begin{array}{ll}\text { Contalner ID: } & 010775 \\ \text { Content Code: } & A-60 \\ \text { Contalner Wt. (Kg): } & 55.7 \\ \text { Origlnal Aasay (g): } & 27.9 \\ \text { Packaglng Location: } & \text { CMB-11, TA-55 } \\ \text { Radionuclide: } & 239 \text { Pu }\end{array}$

\section{RADIOGRAPHIC EXAHIRATIOH}

Exam. Date: No record of radiograph.

L Iner Type:

Le ad-L 1 ned? :

Packaging

Description:

\section{Waste Form}

Description:

\author{
Absorbent? : \\ Free Liqu1ds: \\ Compressed \\ Gas ses: \\ Particulates: \\ Packag $1 \mathrm{ng}$ \\ Eff 1 c 1 ency: \\ Volume $\%$ \\ Combustible: \\ Correct Con- \\ tent Code: \\ WIPP \\ Certif 1 ab 1 e?: \\ M1sce 11 aneous:
}

\section{SUMMARY SHEET}

Age When Opened: $\quad 30$ months

$\begin{array}{ll}\text { Contalner Type: } & 55-g a 1 \text { drum } \\ \text { Code Description: } & 9 \text { ther combustibles } \\ \text { Surface Dose Rate: } & 1 \text { mr } \\ \text { Reasey (g): } & 42.4 \\ \text { Date Packaged: } & 6-02-81\end{array}$

Date ?ackaged:

\section{VISUAL EXAMINATION}

Exam. Date:

Contalner

$1-84$

Condition:

Good, both outside and Inside.

Inner drum very dirty, but structurally sound.

Lead-L1ned?: No

- P I a t $1 \mathrm{c}$

Liner Type:

Packag $1 \mathrm{ng}$

Description: 30-gal drum bagged out in.012"

plastic and put inside a 55-gal drum.

\section{Waste Form}

Uescription: 9 separate bag-out sleeves contalning glass \& metal parts, gloves, paper,

plastic, tape, rags, scrap plastic tubling.

A 1so, loose brown dust in 30-gal drum.

Absorbent: None

Physical State

of Waste: Dry. Danp rags Inside one bagout sleeve, but no free $11 q u 1 d$.

Component Wt. (Kg): 15.8

WIPP-WAC Compliance

Inf ormat 1 on:

Packaging Efficiency: $10 \%$ vold

Volume \% Combustible: $90 \%$

Correct Content

Code:

WIPP Certiflable?:

Yer:

M1scellaneous:
Y e $\varepsilon$.

*?uantity of brown dust was 1 nsignificant. 


\section{SOMMARY SHEET}

Waste Forn Category: Leached Procesa Residues

$\begin{array}{ll}\text { Contalner ID: } & 010925 \\ \text { Content Code: } & \mathrm{A}-25 \\ \text { Contalner Wt. (Kg): } & 227.3 \\ \text { Origtnal Assay ( } \mathrm{g}): & 32.4 \\ \text { Packaglng Location: } & \text { CMB-1 }, \text { T } \Lambda-55 \\ \text { Radionuclide: } & 239 \mathrm{Pu}\end{array}$

\section{RADIOGRAPRIC EXAHIRATIOH}

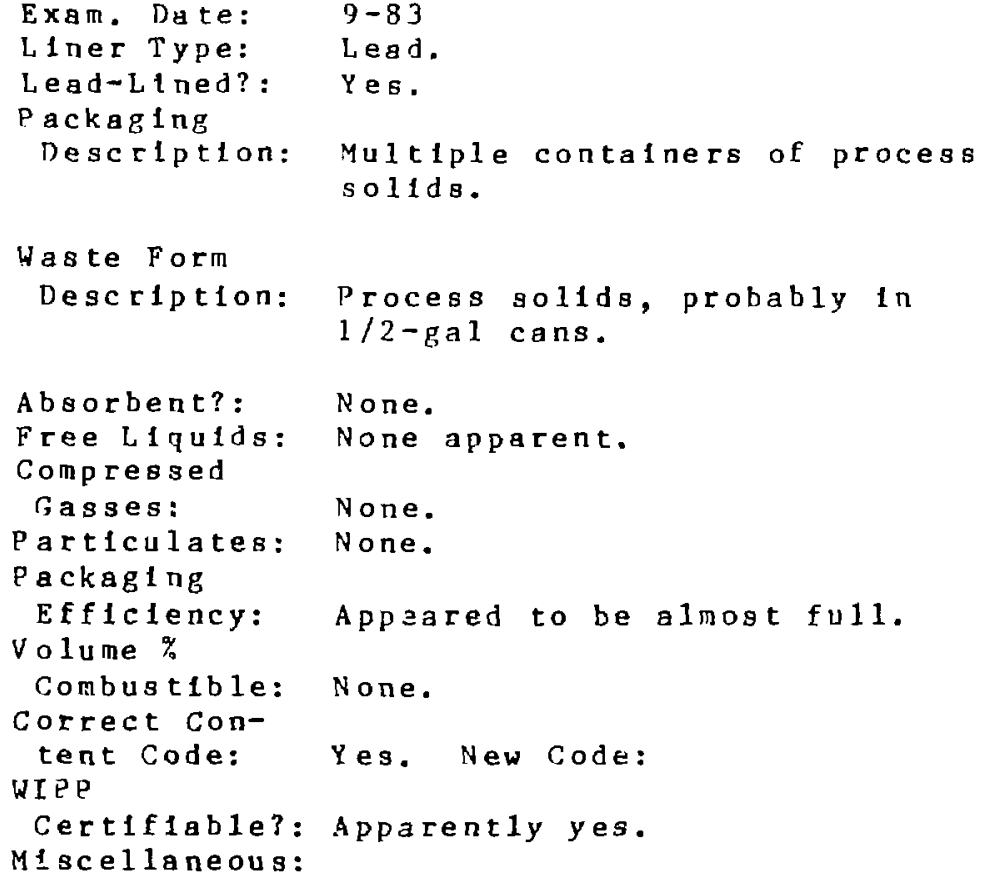

Age when Opened:

30 months

Contalner Type: Code Description: Surface Dose Rate: Reassay $(g)$ : Date Packaged:

$55-g a l$ drum

Leached prozess Res 1 dues $2 \mathrm{mr}$

Not done. Too heavy for $6-24-81$ equ 1 pment.

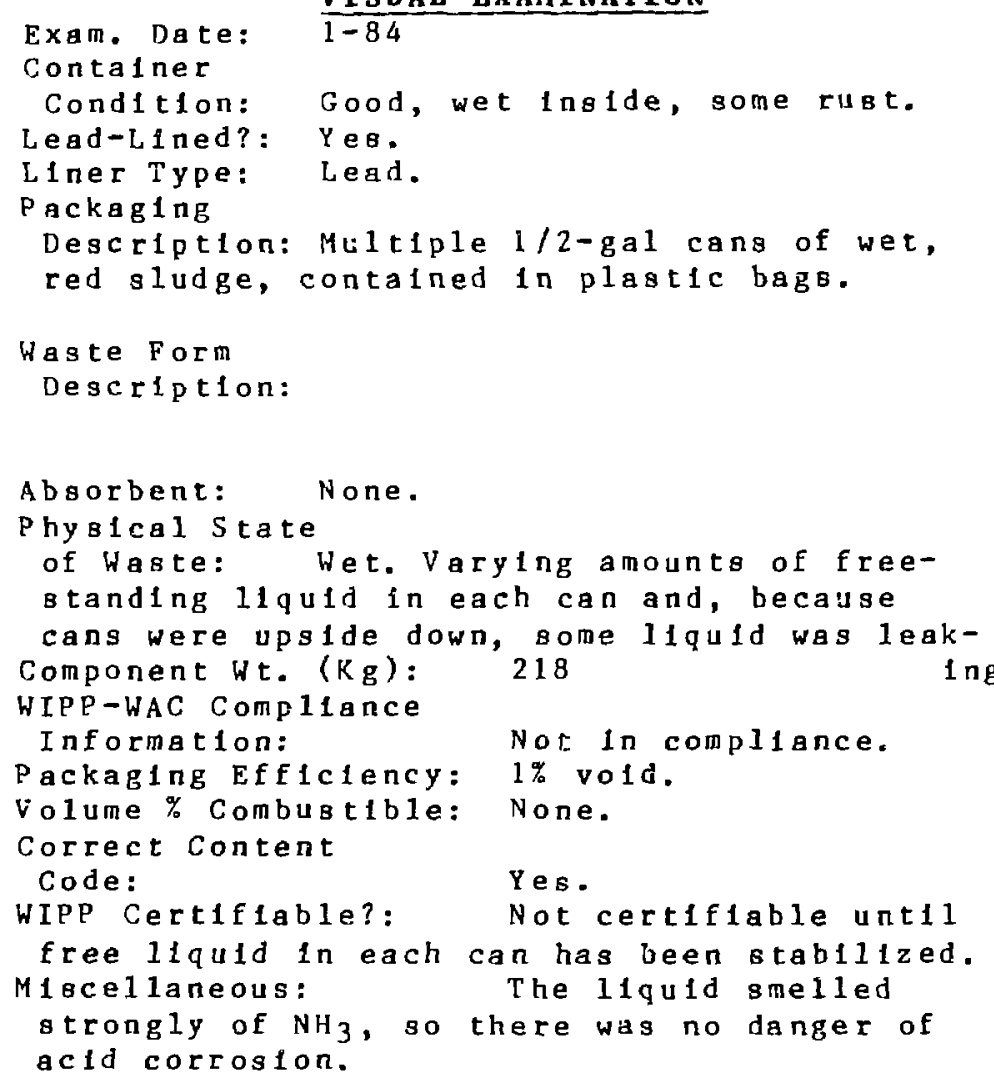




\section{Waste Form Category: Plastic Materlalo}

$$
\begin{aligned}
& \text { Contalner ID. } \\
& \text { Contalner Wt. (Kg): } 58.3 \\
& \text { Origina } 1 \text {. Assay ( } \mathrm{g}): \quad 63 \\
& \begin{array}{ll}
\text { Packagling Location: } & \text { MST-DO, TA-55 } \\
\text { Radionuclide: } & 239 \text { Pu, } 241_{\text {Am }}
\end{array}
\end{aligned}
$$

\section{RADIOGRAPHIC EXAHIHATION}

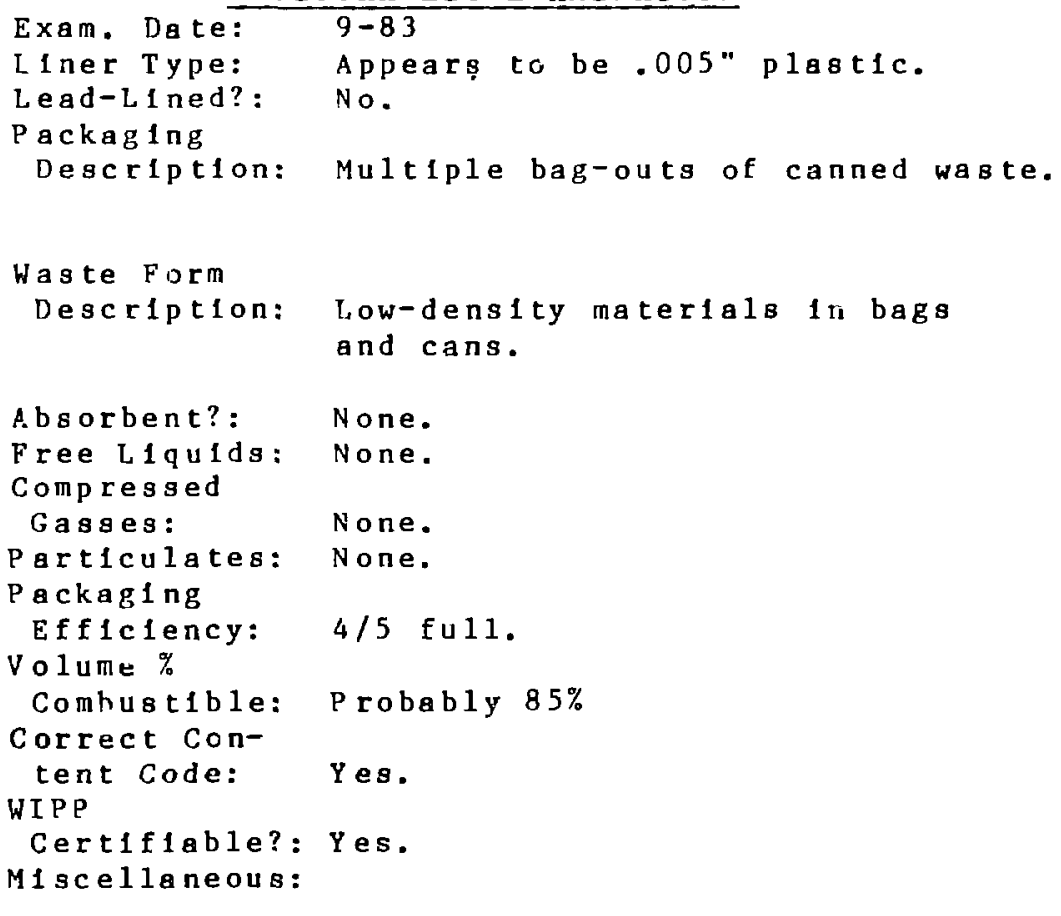

SUHHART SHEET

Age when Opened: 11 months

Contalner Type: 55-ga1 drum

Code Description: Plastic Materials

Surface Dose Rate: $18 \mathrm{mr}$

Reasiay $(g): \quad 65.1$

Date Packaged: $\quad 1-27-83$

\section{VISUAL EXAKINATIOH}

Exam. Date: Drum not opened in SRP.

Contalner

Condit ton:

Lead-L 1 ned?

L 1 ner Type:

packaging

Description:

Waste Form

Description:

\author{
Absorbent: \\ Phys 1cal State \\ of Waste:
}

Component Wt. ( $\mathrm{Kg})$ : WIPP-WAC Comp11ance

Informat 1 on:

Packaging Efficlency:

Volume \% Combustible:

Correct Cantent

Code:

WIPP Certifiable?:

MIsce11aneous: 
Waste Form Category: Nitrate Salts

Contalner I D:

012432

Content Code:

$A-27$

Contalner Wt. ( $\mathrm{Kg}$ )

Orinal A8say (g):

Packaging Location: HST-DO, TA-5 5

Rad I onuclide:

$239 \mathrm{Fu}$

RADIOGRAPHIC EXAHINATION

Exam. Date:

Not radiographed.

Liner Type:

Lead-Lined? :

Packag1ng

Descrtption:

Waste Form

Description:

Atsorbent?:

Free L L quids:

Compressed

Gasses:

Part 1 culates:

$P$ ackaging

Efficiency:

Volume \%

Combustible:

Correct Con-

tent Code:

WIP P

Certifiable?:

Migcellaneous:

\section{SUMHARY SHEET}

Age When Opened: 11 montho

Container Type: $55-g a l$ drum

Code Description: Nitrate Salts

Surface Dose Rate: I mr

keassay $(g)$ :

Not done.

Date Packaged

$1-27-83$
Absorbent.

Phystcal State

of ilaste:

Component Wt. (Kg):

WIPP-WAC Compliani:e

Inforinat 1 on:

Packaging Efficlency:

Volume \% Combustible:

Correct Content

Code:

Miscellaneous:
Poss1bly. 


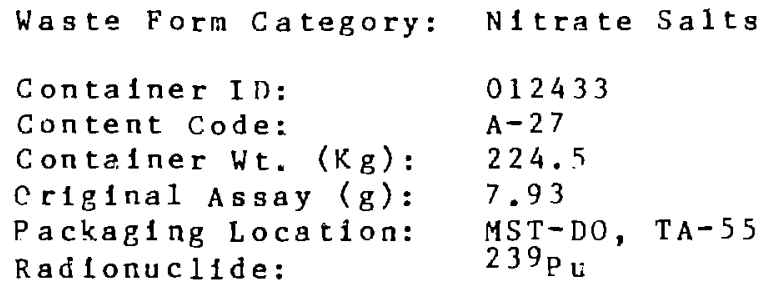

\section{RADIOGRAPHIC EXAMINATION}

Exam. Date:

in iner Type:

Lead-Lined?:

Packaging

Description:

Waste Form

Description:

Absorbent? :

Free L 1 qu $1 \mathrm{~d}$ s:

Compressed

Sas aes:

Particulates:

Packaging

Eff 1 c lency:

Volume \%

Combust 1 ble?

Correct Con-

tent rode:

WIP P

Certif 1 able?

M1scellaneous:

\section{SUMAARY SHEET}

Age when Jyned: 11 months

Contalner Type:

Code Description:

Surface Dose Rate:

Reassay ( $g$ ):

Date Packaged:

55-gal drum

Nitrate Salts

$4 \mathrm{mr}$

Not done.

$1-27-83$

\section{YISUAL EXAMINATIOH}

Exam. Date:

Contalner

Condition:

I.ead-l 1 ned?

L 1 ner Type:

Packag $1 \mathrm{ng}$

Description:

Waste Form

Description:

Absorbent:

Phys 1cal state

of Waste:

Component wt. ( $\mathrm{Kg})$ :

WIPP-HAC Compliance

Informat 1 on:

Packaging Efficiency:

Volume \% Combustible:

Correct Content

Code:

WIPP Certifiable?: Possibly.

Msce11aneous: 


\section{SUMMARY SHEET}

\section{Waste Form Category: Chemlcal treatment sludge}

Container I D:

Content Code:

012124

A -75

201.9

$0.017,0.17,0.35$

Original fesay (g)

Packaglng Lucation:

Rad 1 onuc 11 de:

\section{RADIOGRAPHIC EXAHINATION}

Exam. Date: $9-83$

Ltner Type: $\quad 90-m i 1$

Lead-L1 ned?: No.

Packaging

Description: 90-mil HDPE liner.

\section{Waste Form}

Description: siudge.

\section{Absorbent?: Portland cement}

Free Liquids: None.

Compressed

Gasses:

Nore.

Parciculates:

Meets criteria.

Packaging

Efficlency: Full.

Volume \%

Combustible: None.

Correct Con-

tent Code:

Y e 8 .

WIPP

Certiflable?: Yes.

Miscellaneous:

Age when opened:

Contalner Type:

Code Description:

Surface Dose Rate:

Reasegz (g):

Date Packaged:

\section{Approx, 1 year}

55-gal drum

Chemical treatment sludge

5 mir

Not done.

$01-26-83$

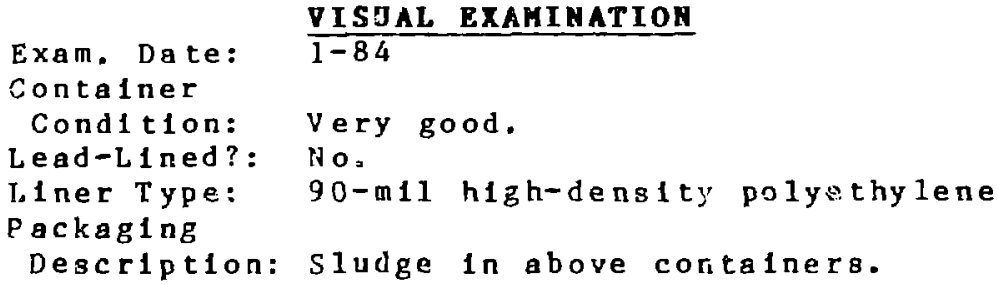

M1sce 11 aneous: 


\section{SUAMART SHEET}

\begin{tabular}{|c|c|}
\hline Waste Form Category: & Chem lcal treatment \\
\hline Contalner I L: & 012307 \\
\hline Content Code: & $A-75$ \\
\hline Container Wt. (Kg): & 201.9 \\
\hline Orfglna 1 Assay $(g):$ & $0.017,0.17,0.35$ \\
\hline $\begin{array}{l}\text { Packaglng Location: } \\
\text { ?adlonuclide: }\end{array}$ & $\begin{array}{l}\mathrm{TA}-50 \\
238 \mathrm{Pu}, 239 \mathrm{Pu}, 241 \mathrm{Am}\end{array}$ \\
\hline
\end{tabular}

\section{RADIOGRAPHIC EXAMINATION}

Exam. Date: 9-83

Liner Type: $\quad 90-\mathrm{m} 11$

Lead-L1ned?: No.

Packa $\sigma 1 \mathrm{ng}$

Description: $90-$ in 11 HIPE 11 ner.

Wagte Form

Description: Sludge.

Absorbent?: Portland cement.

Free L I quids. None.

Compressed

rase: s:

None.

Particulates: Meets criteris.

Packag $1 \mathrm{ng}$

Efficiency: Ful1.

$\checkmark$ olume \%

Combustible:

Correct Con-

tent code: Yes.

WI PP

Certiflable?: Yes.

M1sce11anecus:

Age When Opened:

Container Type:

Code Description:

Surface Dose Rate:

Reassay $(g)$ :

Date Packaged:

Approx. 1 year

55-ga 1 drum

Chemlcal trewtinent sludge

6 in $r$

Not done

$0 \mathrm{i}-24-83$

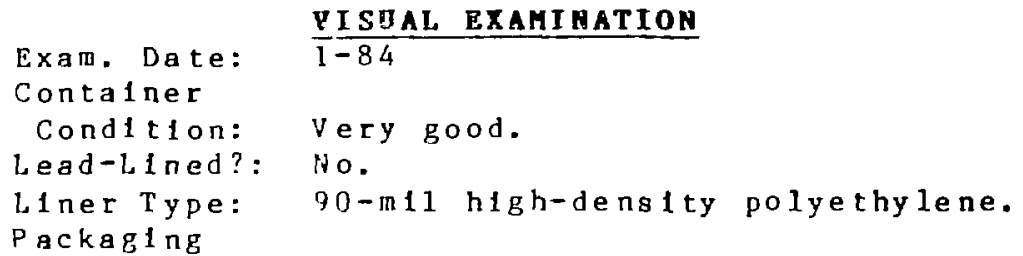

Abrorbent: None.

Phys lca 1 State

of Waste: Sol1d. No free $11 \mathrm{qu} 1 \mathrm{~d}$.

Component wt. (Kg): 179.2

WIPE-WAC Compliance

Information: Should be certiflable.

Packaging Efficlency: $95 \%$

Volume \% Combust 1 ble: None.

Correct Content

Code:

None.

WIPP Certif table?:

M 1 sce 11 a neous: 


\section{SUMMARY SBEET}

\begin{tabular}{|c|c|}
\hline Waste Form Category: & Chemlcal treatment \\
\hline $\begin{array}{l}\text { Contalner ID: } \\
\text { Content Code: } \\
\text { Contalner Wt. ( } \mathrm{Kg}): \\
\text { Origlnal Asgay (g): } \\
\text { Backaglng Jocation: } \\
\text {;nllonuclide: }\end{array}$ & $\begin{array}{l}012327 \\
\mathrm{~A}-75 \\
201.9 \\
0.017,0.17,0.36 \\
\text { TA-50 } \\
238_{\mathrm{Pu}}, 239 \mathrm{Pu}, 241_{\mathrm{Am}}\end{array}$ \\
\hline
\end{tabular}

\section{ludge}

\section{RADIOGRAPHIC RXANINATIOH}

Exam. Date: $9-83$

Liner Type: $\quad 90-m 11$

Leat-Lined? : INo.

$P$ ackag $1 \mathrm{ng}$

Description: 90-mil HDPE 11 ner.

Waste Form

Description: Sludge.

Absorbent?: Portland cement.

Free Liquids: None.

Compressed

Gas 8 es:

None.

Particulates: Meets criteria.

Packag1 ng

Effictency: Full.

Volume \%

Combustibla: None.

Correct Con-

tent Code: Yes.

WIPE

Certifiable?: Yes.

M1scerlaneous:
Age when Opened:

Container Type:

Code Description:

Surface Doвe Rate:

Reassay ( $g)$ :

Date Packaged:

Approx. 1 year

55-gal drum

Chemical treatment sludge

$\mathrm{mr}$

Not done

$01-27-83$

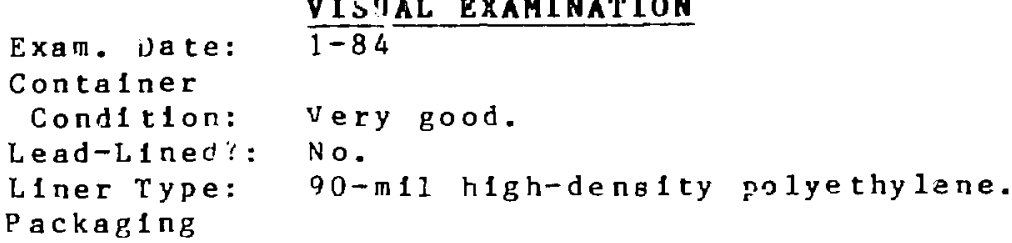

Absorbent: None.

Physical State

of Waste: Sol1d. No free $11 q u 1 d$.

Component Wt. ( $\mathrm{Kg})$ :

179.2

WIPP-WAC Compliance

Information: 5nould be possible to certify.

Packaglng Efflclency: $95 \%$

Volume \% Combustible: None.

Correct Content

Code:

Yes.

WIPP Certifiable?: Yes

Mfscellaneous: 
SUMMARY SHEET

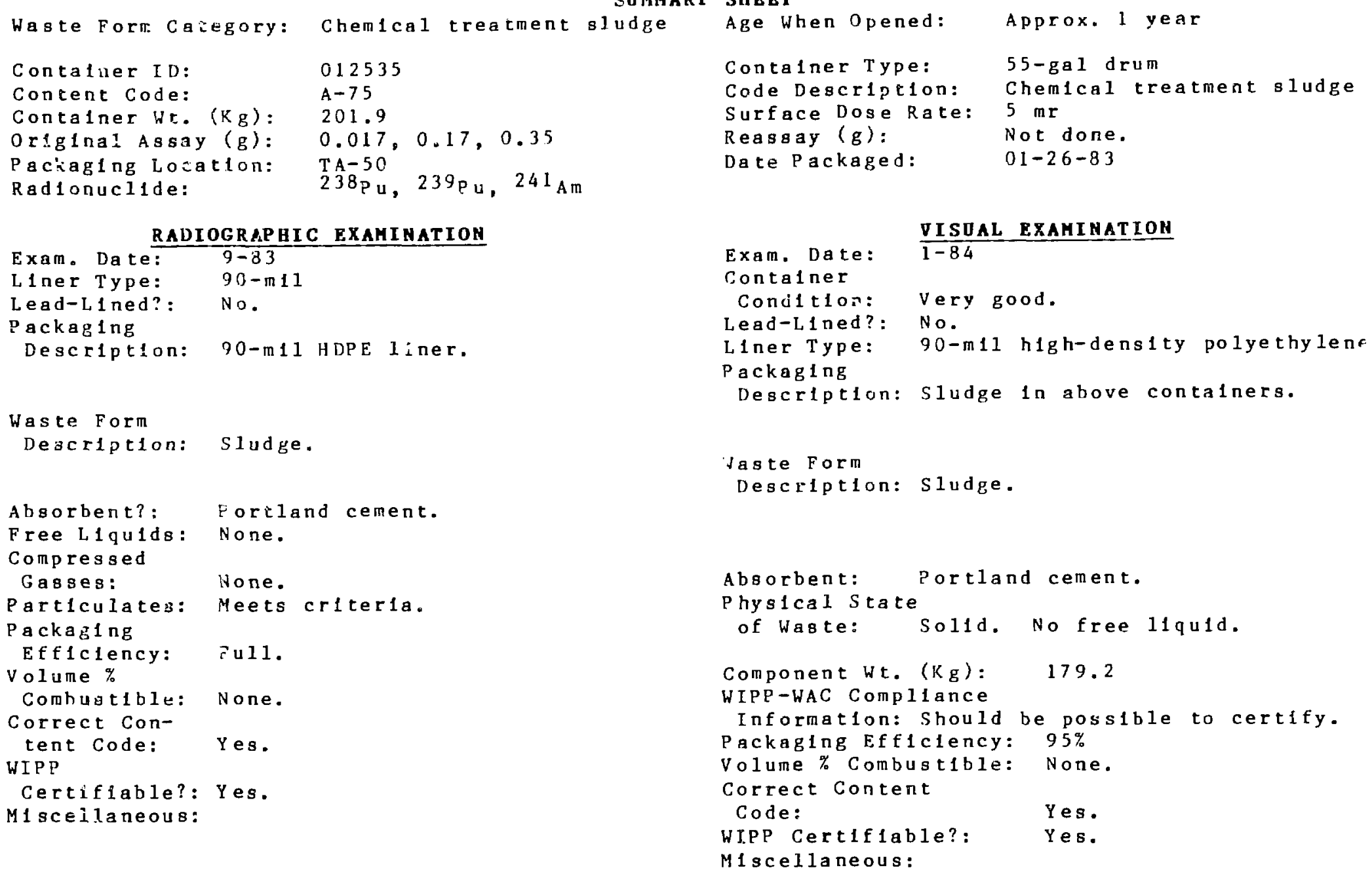


APPENDIX 3

WASTE CONTAINER COMPONENT WEIGHTS 
TABLE VIII

WASTE DONTAINER DMPONENT WEIGHTS (kg)

Waste Porm Category: Consustitles

Isotope: $238^{3}$ u

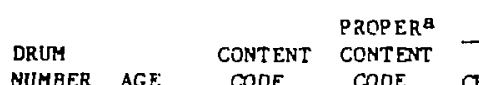

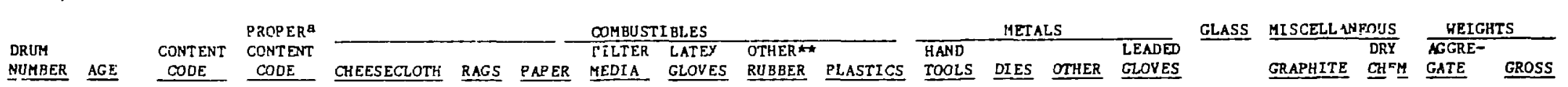

IPB-12 39 mo $A-60$

$\mathrm{APB}=1436$ mo $A-60$

BPB-19 37 по A-61

$B F B-2036$ mo $A-60$

$B F B-26 \quad 35$ no $A-60$

$B P B-2735$ mo A-60

$\mathrm{BFB}-927$ To $\mathrm{A}-19$

BFB-96 8 mo $A-19$

$B F b-97 \quad 8$ प0 $A-19$

BFB-101 8 mo $A-18$

$B F B-1027$ mo $A-19$

$B F B-1037$ mo $A-19$

BFB-234 9y 3 mo $A-19$

$B F B-235$ 3y $3 m o ~ A-18$

BFB-237 9y 3 mо $A-19$

$B F B-238$ 9y 3 mo A-18

BFB-233 9y 3mo $A-18$

$\star$

A-19

$A-19$

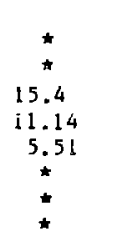

$A-19$

$A-61$

$A-61$

$A-61$

$B F B-240$ 9y 3mo $A-19$

$A-61$

B. Proper content code Indicated only If original is wrong or Inappropriate.

- Visual examination revealed that packages of waste within a drum were of ten not limited to one spectfic type of material; aefther were they segregated 1ato cuabustibles and noncombustibles. In these cases a $\vec{f}$ mixed contents, an aggregrate weight 19 given, and asterisks 1 adicate which camponents are present.

wh Not leaded. 
WASTE CONTAINER OOMPONENT WIGHTS ${ }^{a}(\mathrm{~kg})$

h gte Porm Categorr: Comburtibies

I sut.ope: $\quad 23{ }^{3} \mathrm{~K}$

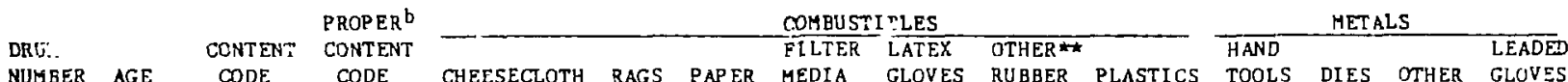

NUMBER AGE CODE CODE CHEESECLOTH RAGS PAPER MEDIA GLOVES RUBBER PLASTICS TOOLS DIES OTHER GLOVES

$10761 \quad 11$ mo $A-14$

10753 11 $70 \quad A-16$

012223 11 प1 $A-16$

007060 11 mo $\mathrm{A}-18$

$010362 \quad 12$ too $A-18$

01060511 mo A-18

01075630 mo $A-60$

01077530 mo $A-60$

$A-12$

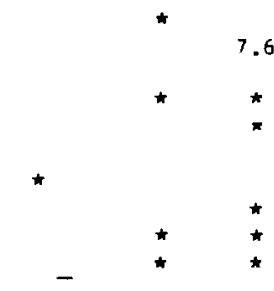

6.3

$A-19$

a. Data based on the results of visual examinations where performed.

b. Proper content code Indicated cnly if origlnal ts wrong or Inapproprlate.

* Visual exaqination revealed that packages of waste within a drum wers of ten rot liafted to one specific type of aaterial: nelther were they segregated into combustibles and noncombuatibles. In these cases of mixed contents an aggregate welght ls given, and asterisikg indicate uhich conponents are present.

Not leaded. 
TABLE $X$

WASTE CONTAINER OOMPONENT WEIGH'CQB (kg)

Wagre Porm Cacegory: Voncombustibleg

I go tope: $239 \mathrm{Pu}$

\begin{tabular}{|c|c|c|c|c|c|c|c|c|c|c|c|}
\hline NUMBER & $A C E$ & $\begin{array}{c}\text { CONTENT } \\
\text { CODE } \\
\end{array}$ & $\begin{array}{l}\text { PROCESS } \\
\text { SOLIDS }\end{array}$ & $\begin{array}{l}\text { NITHATE } \\
\text { SALIS }\end{array}$ & $\begin{array}{l}\text { SLAG AND } \\
\text { CRUCI BLE }\end{array}$ & $\begin{array}{l}\text { HEVICh' } \\
\text { TREATMENT } \\
\text { SLLIDEE } \\
\end{array}$ & METALS & $\begin{array}{l}\text { NON- } \\
\text { COMBL, SI BLE } \\
\text { (NOIBN) }\end{array}$ & ORGANICS & DDMYENTS & $\begin{array}{l}\text { GROSS } \\
\text { WELGHT }\end{array}$ \\
\hline $\begin{array}{l}010925 \\
010411\end{array}$ & $30 \mathrm{mo}$ & $\begin{array}{l}A-25 \\
A-25\end{array}$ & * Banlc & red gludg & multiple co & ners, appro & lba each & & & & $\begin{array}{l}520 \\
129\end{array}$ \\
\hline 010108 & $\begin{array}{l}12 \text { mо } \\
25 \text { mо }\end{array}$ & $\begin{array}{l}A-23 \\
A-25\end{array}$ & $\star$ & & 4.68 & $25.89^{+}$ & 2.68 & & 0.19 & Includes $\mathrm{CaCl} 1_{2}$ & 63.5 \\
\hline 010494 & $12 \mathrm{mo}$ & $A-47$ & & & * & & & & & $198 g^{239}$ u & 154. \\
\hline 010435 & 12 mo & $A-52$ & & & $\star$ & 56.45 & 100.36 & & & & 220. \\
\hline 010645 & 11 ne & $A-51$ & & & & & & $\because 144$. & & & 194. \\
\hline 012124 & 12 mo & $\begin{array}{l}A-75 \\
A-75\end{array}$ & & & & $\star$ & & & & & $444^{\circ}$. \\
\hline $\begin{array}{l}012307 \\
012327\end{array}$ & $\begin{array}{l}12 \mathrm{mo} \\
12 \mathrm{mo}\end{array}$ & $\begin{array}{l}A-75 \\
A-75\end{array}$ & & & & 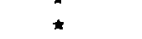 & & & & & 444. \\
\hline 012535 & 12 mo & $A=75$ & & & & $\star$ & & & & & 444. \\
\hline
\end{tabular}

a. Data based on the resultg of vigual examinations vihere performed.

NOIBN = Nat otheralge identifled by name.

* Visual examination revealed that packageg of wasti within a drum werc of ten not 11mited to one specific type of matertal; nelther were they segregated into combustlbles ind noncombustbles. In these cares of mixed contents, an aggregrate weight ls given, and asterlsks indicate which components are present. 


\section{APPENDIX 4}

WASTE FORM COMPLIANCE WITH THE WIPP-WAC 
TABLE XI

WASTE PORM OOMPLIANCE HITH THE WIPP-HACa

Waste Fond Categary: Combustibles

\begin{tabular}{|c|c|c|c|c|c|c|c|c|c|c|c|c|c|c|c|}
\hline $\begin{array}{l}\text { DRUR. } \\
\text { NUMB } R\end{array}$ & $\underline{A G E}$ & & I SOTOPE & $\begin{array}{l}\text { QUANTITY } \\
\text { (GMS) } \\
\end{array}$ & $\begin{array}{l}\text { CONTENT } \\
\text { CODE } \\
\end{array}$ & $\begin{array}{l}\text { PROFEK } \\
\text { CONTENT } \\
\text { OODE } \\
\end{array}$ & $\begin{array}{l}\text { IMMOBILIZED } \\
\text { PART I CULATE } \\
\end{array}$ & $\begin{array}{c}\text { PREE } \\
\text { LIOUID } \\
\end{array}$ & SLUDGE & PYROPHORICS & $\begin{array}{l}\text { EXP LOSIVES/ } \\
\text { COMPRESSED } \\
\text { GASES } \\
\end{array}$ & $\begin{array}{l}\text { MOXIC/ } \\
\text { CORROSIVE } \\
\text { MATERIALS }\end{array}$ & $\begin{array}{l}\text { ORGANIC } \\
\text { DDNTENT } \\
\text { (RG) } \\
\end{array}$ & CERTI & IABE \\
\hline$B F B-92$ & & mo & $238 \mathrm{pu}$ & 7.7 & $A-18$ & $A-19$ & YES* & No & NO & No & NO & NO & 1.93 & YES & YES \\
\hline$B 8 B-101$ & & mo & $23 S_{p} u$ & 11.6 & $A-18$ & & No & No & no & No & No & No & 8. 2 & YES & YES \\
\hline$B F B-234$ & $9 y$ & 3 tmo & $238 \mathrm{pu}$ & 22.7 & $A-18$ & $A-19$ & No & No & NO & no & No & YES & 0.7 & YES & NO \\
\hline $\mathrm{BFB}-235$ & Sy & 3 mo & $238 \mathrm{Pu}$ & 1.9 & $A-18$ & $A-61$ & No & NO & No & NO & No & No & 2.95 & YES & YES \\
\hline$B F B-237$ & $9 y$ & 3 mo & $238 \mathrm{pu}$ & 4.2 & $A-13$ & $A-61$ & No & No & NO & NO & NO & No & 3.86 & YES & YES \\
\hline $5 r B-238$ & & 3 mo & $238 \mathrm{Pu}$ & 0.5 & $A-1 B$ & $A-51$ & No & NO & NO & NO & No & No & 2.95 & YES & YES \\
\hline BF B -239 & $9 y$ & 3 mo & 238 u & 1.4 & $A-13$ & $A-61$ & No & No & No & NO & No & No & 4.59 & YES & YES \\
\hline$B F B-240$ & $9 y$ & 3 mo & $238_{\mathrm{p} u}$ & 1.7 & $A-18$ & $A-61$ & No & YES & NO & NO & No & NO & 2.95 & YES & No \\
\hline $\mathrm{BFB}-12$ & 39 & mo & $238_{\mathrm{p}} \mathrm{u}$ & 6.6 & $A-60$ & $A-19$ & No) & NO & No & NO & No & No & 3.2 & YES & YES \\
\hline$B F B-14$ & 36 & mo & $238 p u$ & 1.3 & $A-60$ & $A=14$ & No & NO & No & NO & No & No & 9.4 & YES & YES \\
\hline $\mathrm{EFB}-20$ & 36 & mo & ${ }^{238} \mathrm{P}_{\mathrm{P}}$ & 2.2 & $A-60$ & $A-16$ & No & No & No & NO & No & No & 14.0 & YES & YES \\
\hline$B ? B-26$ & 35 & mo & $238_{\mathrm{pu}}$ & 1.05 & $A-60$ & $A-19$ & NO & No & NO & No & NO & No & 7.4 & YES & YES \\
\hline$B F B-27$ & 35 & mo & $238 p_{4}$ & 1.18 & $A-60$ & $A-18$ & No & NO & No & NO & No & No & 14.7 & YES & YES \\
\hline$B F B-96$ & 8 & mo & $-39 ? 4$ & 10.2 & $A-19$ & & No & No & No & No & No & No & 8.4 & YES & YES \\
\hline$B F B-97$ & 8 & mo & $-38 p_{u}$ & 9.4 & $A-19$ & & No & No & No & NO & No & No & 7.02 & YES & YES \\
\hline $\mathrm{BFB}-\mathrm{L} 02$ & 7 & mo & $238_{?} \mathrm{u}$ & 3.4 & $A-19$ & & No & NO & No & No & No & No & 2.98 & YES & YES \\
\hline $3 F \forall-103$ & 7 & هo & $238 p_{u}$ & 6.8 & $A-19$ & & No & No & NO & NO & NO & No & 6.1 & YES & YES \\
\hline $8 F B-19$ & 37 & mo & $238 p \mathrm{p} u$ & 5.6 & $A-6 d$ & & No & NO & NO & No & NO & NO & 0.75 & YES & YES \\
\hline
\end{tabular}

a. Data bas id on the results from the visual examinationa.

b. Pzoper cuntent code Indfcated only if orlginal is wrong or Inapproprtate.

c. Rea!-Time Radfograpity.

* Yey, but withic al lowable $11 \mathrm{~m} 1 \mathrm{ts}$ or requl rements. 
TABLE XII

WASTE FORM OOMPLLANCE WITH THE WIPP-HAC

Haste Form Category: Combugtibles

\begin{tabular}{|c|c|c|c|c|c|c|c|}
\hline $\begin{array}{l}\text { DRUM } \\
\text { NUMBER }\end{array}$ & ALE & I SOTUPE & $\begin{array}{l}\text { QUANTITY } \\
\text { (GMS) } \\
\end{array}$ & $\begin{array}{l}\text { CONTENT } \\
\text { CODE } \\
\end{array}$ & $\begin{array}{l}\text { PROP ER } \\
\text { CONTENT } \\
\text { CODE }\end{array}$ & $\begin{array}{l}\text { IMHOBILI ZED } \\
\text { PARTL LULATE }\end{array}$ & $\begin{array}{c}\text { PREE } \\
\text { LIQUID }\end{array}$ \\
\hline 010761 & 11 mo & $239 p_{\mathrm{pu}}$ & 0.47 & $A-14$ & & (1) & YES \\
\hline 010753 & il mo & $239 \mathrm{Pu}$ & 46 & $A-16$ & $A-18$ & YES & No \\
\hline 012223 & $11 \mathrm{mc}$ & $239_{\mathrm{Pu}}$ & 63 & $A-16$ & & NO & No \\
\hline 007060 & 11 mo & $239 \mathrm{pu}$ & 3.3 & $A-18$ & & הo & กо \\
\hline 007226 & $11 \mathrm{mo}$ & $239 \mathrm{Pu}$ & 0.4 & $A-18$ & & NO & No \\
\hline 010362 & $12 \mathrm{mo}$ & $239 \mathrm{Pu}$ & 26.2 & $A-18$ & & NO & NO \\
\hline 010605 & $11 \mathrm{mo}$ & $239 \mathrm{Pu}$ & 122 & $A-19$ & $A-15$ & NO & No \\
\hline 010756 & 30 mo & $239 \mathrm{Pu}$ & 0.0 & $A-60$ & $A-19$ & NO & No \\
\hline 010775 & $30 \mathrm{mo}$ & $239 \mathrm{pu}$ & 27.9 & $A=60$ & & No & NO \\
\hline 020773 & $11 \mathrm{mo}$ & $239 \mathrm{pu}_{\mathrm{u}}$ & 0.1 & $A-19$ & & NO & NO \\
\hline
\end{tabular}

a. Data baged on the results of vigual examinations where petertar ?.

b. Proper content code inclcated only if original ig wrong or inappopriate.

c. Real-Time Radlography.

* Yes, but wirin allowable limits or requirements.

XX Drum not opened for visuai exarination.

NN Thls drum was not radtographed.

\begin{tabular}{|c|c|c|c|c|}
\hline \multirow{2}{*}{$\begin{array}{l}\text { EXP LOSIVES } / \\
\text { COMPRESSED } \\
\text { GASES } \\
\end{array}$} & \multirow{2}{*}{$\begin{array}{l}\text { TOXIC/ } \\
\text { ORROSIVE } \\
\text { MATERIALS }\end{array}$} & \multirow{2}{*}{$\begin{array}{l}\text { ORG AN IC } \\
\text { CONT ENT } \\
(\mathrm{KG}) \\
\end{array}$} & \multicolumn{2}{|c|}{ CERTIFLABL,E } \\
\hline & & & $\underline{\operatorname{RTR}^{c}}$ & WIPP \\
\hline NO & No & 18.3 & YES & No \\
\hline NO & No & 6.3 & YES & YES \\
\hline NO & NO & 49.6 & YES & $x x$ \\
\hline No & No & 19.7 & אผ & YES \\
\hline NO & No & 21.9 & YES & YES \\
\hline NO & No & 26.7 & YES & $x x$ \\
\hline No & No & 7.9 & NN & YES \\
\hline NO & No & 7.6 & YES & YES \\
\hline NO & NO & 14.2 & NN & YES \\
\hline NO & No & 20.7 & NN & YES \\
\hline
\end{tabular}


WASTE FORM DIAPLIANCE WITH THE WIPP-WAC

Waste Form Category: Noncombustibles

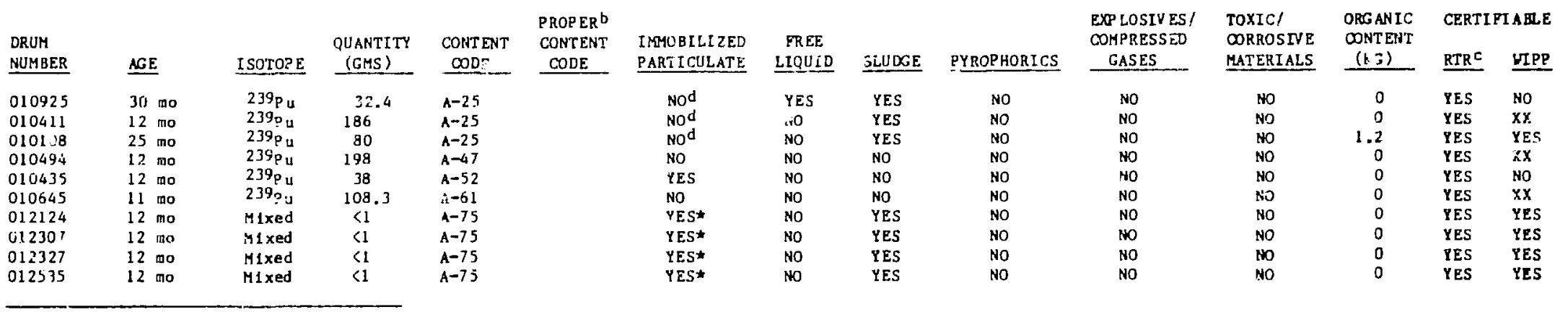

a. Data based on the results of visual exantnations where performed.

b. Proper content code indicated only if orighal is wrong or Inappopridte.

c. Real-T Ime Radiography.

d. See note rugariling waste process gollda in Discussion of Studles aection.

XX Drum not wiped for vlguas examination.

NN Th1s drum was not radiographed.

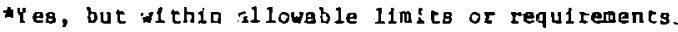

